\title{
PTOLEMAIC ORBS IN TWELFTH-CENTURY ENGLAND A STUDY AND EDITION OF THE ANONYMOUS LIBER DE MOTIBUS PLANETARUM
}

\author{
C. Philipp E. Nothaft \\ All Souls College, OXFord
}

\begin{abstract}
This article offers the first study and critical edition of the Liber de motibus planetarum ( $(\mathrm{mp})$, a neglected Latin text on planetary theory that appears anonymously and without any clear indication of date or place of origin in nine manuscripts of the thirteenth to fifteenth centuries. An analysis of its sources and parallels to other Latin treatises and translations from Arabic indicates that the Lmp originated in England in the third quarter of the twelfth century. A plausible terminus post quem is provided by the appearance of similar passages in the anonymous treatise Ptolomeus et multi sapientum (1145), which can be linked to Abraham Ibn Ezra and his astronomical tables for the meridian of Pisa. The Lmp would appear to be historically significant for its relatively detailed textual and diagrammatic presentations of Ptolemy's planetary models as composed of multipart physical orbs. While it is generally accepted that physicalized or 'orbed' versions of these models entered Latin astronomy through the influence of Ibn al-Haytham's Maqāla fì hay'at al-'âlam (On the Configuration of the World), the early history of this idea in a Latin context has not been studied to any deeper extent. In this regard, the Lmp offers clear evidence that Ptolemaic orbs and diagrams representing them already were a part of Latin astronomy three centuries before Peuerbach's Theoricae novae planetarum (1454).
\end{abstract}

Key Words

Latin astronomy, Islamic astronomy, Latin translations, Ptolemy, Abraham Ibn Ezra, Ibn al-Haytham. 


\section{Introduction}

The translation of Arabic scientific works into Latin and the ensuing Renaissance of the exact sciences in twelfth-century Europe led to such an outburst of intellectual productivity that only a small fraction of the relevant source material has ever received close scrutiny from modern scholars. Neglect of this sort has been especially common for anonymous texs in fields such as astronomy and mathematics, whose origin and date are often difficult to ascertain. A perfect example is the brief introduction to planetary theory with the incipit Investigantibus astronomie rationes primo ponendum, which in two of the nine extant copies carries the descriptive title Liber de motibus planetarum. ${ }^{1}$ The main goal of the present article is to provide a critical edition of this obscure text, which to my knowledge has never been the object of any serious sort of study. ${ }^{2}$ My edition will be preceded by an introduction in four parts. In the first I shall discuss one of the most intriguing features of the Liber de motibus planetarum-or Lmp, as I shall henceforth call it: its endorsement of physicalized versions of Ptolemy's planetary models, which are closely related to the multipart orb models described at much greater length in Ibn al-Haytham's Maqāla fì hay'at al-älam (On the Configuration of the World). The Lmp does not merely allude to the existence of these physicalized models, but offers detailed descriptions and drawings of planetary diagrams that are meant to depict Ptolemy's epicycles and eccentric deferents as nested orbs or orb segments. In light of this feature, the Lmp may even be viewed as a hitherto unknown forerunner to the Theoricae novae planetarum by Georg Peuerbach, which popularized orb models of this type in the fifteenth century.

Part II seeks to establish that the Lmp originated in England in the third quarter of the twelfth century, more specifically between 1145 and 1176. For evidence to support this contention, I shall rely on textual parallels between the Lmp and other Latin astronomical works from the twelfth century. These include Walcher of

1 The title Liber de motibus planetarum appears in MSS $E$ and S. Similar labels are used in P (De motibus planetarum secundum Abraham) and $V$ (Theorica in motibus septem planetarum). For sigla and descriptions of these and all the remaining manuscripts, see section IV below.

2 The text was listed among the dubia of Robert Grosseteste by S. Harrison Thomson, The Writings of Robert Grosseteste, Bishop of Lincoln 1235-1253, Cambridge: University Press, 1940, p. 235 (mentioning manuscripts DRV). See previously already Ludwig Baur, Die philosophischen Werke des Robert Grosseteste, Bischofs von Lincoln, Münster: Aschendorff, 1912, p. 61*, n. 1, who knew D and R. Remarks on the text based on $F$ appear in Pierre Duhem, Le système du monde: histoire des doctrines cosmologiques de Platon à Copernic, vol. III, Paris: Hermann, 1915, p. 316. The work's existence was again noted by Francis S. Benjamin, Jr, and G. J. Toomer, Campanus of Novara and Medieval Planetary Theory, Madison: University of Wisconsin Press, 1971, pp. 88-89, who were the first to mention BX. Manuscripts of the Lmp are also noted in Fritz S. Pedersen, 'A Twelfth-Century Planetary Theorica in the Manner of the London Tables', Cahiers de l'Institut du Moyen-Âge Grec et Latin 60 (1990), pp. 199-318, at p. 199, n. 1, who knew all copies except P. I am very grateful to David Juste for bringing the latter to my attention. 
Malvern's De Dracone (1120) and an anonymous treatise beginning with the words Ptolomeus et multi sapientum (1145), which is linked to Abraham Ibn Ezra and the Pisan Tables. Two works that appear to have drawn on the Lmp are Roger of Hereford's Compotus (1176) and an anonymous planetary Theorica from the later twelfth century, which features a similar set of opening words (Investigantibus astronomiam primo sciendum). The third part expands on this analysis by examining the Lmp's use of two well-known sources translated from Arabic in the first half of the twelfth century: the Toledan Tables (together with their canons starting Scito quod annus lunaris) and al-Farghānì's Elements of Astronomy. The fourth and final part presents the nine extant manuscripts and uses their shared variants to reconstruct the Lmp's transmission in the form of a stemma. This reconstruction will inform the critical edition attached to this article.

\section{A physicalized astronomy}

At first glance the Lmp is no more than a basic primer to the models describing the motions of the seven planets that Ptolemy had laid out in much greater geometrical and kinematic detail in his second-century Almagest. Our text begins with some elementary definitions of points, lines, and circles to obtain a coordinate system for describing the celestial spheres. ${ }^{3}$ From there it moves on to a succinct account of the sphere of the Sun, which includes some remarks on the 'equation' used in calculating true solar longitudes. This section also touches upon the motion of the eighth sphere (sphere of the fixed stars), which is presented in terms of a trepidation model with an amplitude of $8^{\circ}$ as opposed to Ptolemy's linear notion of precession. The text's descriptions of the model for the Moon, the model for Mercury, and the joint model for the remaining four planets are purely qualitative in nature. Specific rates of motion for the Sun, Moon, and Mercury are only provided in a brief summary towards the end (see 1l. 365-389 in the edition below), for which the author drew on al-Farghānī's influential Jawāmi 'ilm al-nujūm or Elements of Astronomy (see section IIIa below). Quantitative data for Venus and the three superior planets are left out altogether. Instead, the Lmp closes with some very brief remarks on the locations of the planetary apogees (auges) and ascending nodes (geuzahar), which can be used to infer a planet's direction in latitude.

A similar type of description may be found in ch. 10 of the short version and ch. 16 of the long version of the Liber de orbe ascribed to Māshā'allāh, which was translated into Latin in the 1130s. See Barbara Obrist, 'William of Conches, Māshā'allāh, and Twelfth-Century Cosmology', Archives d'histoire doctrinale et littéraire du Moyen Âge 76 (2009), pp. 29-87, at pp. 73-74. The author of the original text was Dūnash ibn Tamīm (d. after 955) according to the findings of Taro Mimura, 'The Arabic Original of (ps.) Māshā'allāh's Liber de orbe: Its Date and Authorship', British Journal for the History of Science 48 (2015), pp. 321-352; Id., 'A Glimpse of Non-Ptolemaic Astronomy in Early Hay'a Work-Planetary Models in ps. Mashā’allāh's Liber de orbe’, Suhayl 14 (2015), pp. 89-114. 
Given this overall orientation of content, the $\operatorname{Lmp}$ fits into a category of didactic astronomical works known in the medieval Latin tradition as Theoricae planetarum, as is confirmed by the descriptive titles used in two of the extant manuscripts (FV). The best-known medieval Theorica planetarum survives in well over 200 copies and carries the incipit Circulus eccentricus vel egresse cuspidis. ${ }^{4}$ Since the late Middle Ages, this text has sometimes been attributed to Gerard of Cremona, the prolific twelfthcentury translator of texts from Arabic (d. 1187), yet no one has been able to demonstrate conclusively its existence prior to $c .1230$, the approximate date of Michael Scot's Liber introductorius. ${ }^{5}$ Despite the shared subject matter, the similarities between the Lmp and the pseudo-Gerardian Theorica planetarum remain relatively superficial. One case in point are the planetary diagrams that accompany both texts. ${ }^{6}$ In the case of the $\operatorname{Lmp}$, at least four such diagrams were intended by the author and have been preserved, to different degrees of completeness, in six of the known manuscripts (DEFRVX). They represent the kinematic elements of the Sun (Fig. 1), the Moon (Fig. 2), and (Fig. 3) Mercury as well as the joint model for Venus and the superior planets (Fig. 4), together with some lines indicating the

4 For an edition of this text, see Francis J. Carmody, Theorica Planetarum Gerardi, Berkeley, CA, 1942. Some excerpts were printed in Lynn Thorndike, Michael Scot, London: Nelson, 1965, pp. 132-138. An English translation appears in Edward Grant (ed.), A Source Book in Medieval Science, Cambridge, MA: Harvard University Press, 1974, pp. 451-465. For discussion, see Olaf Pedersen, 'The Theorica planetarum-Literature of the Middle Ages', Classica et Mediaevalia 23 (1962), pp. 225-232; Id., 'The Decline and Fall of the Theorica Planetarum: Renaissance Astronomy and the Art of Printing', in Erna Hilfstein, Paweł Czartoryski and Frank D. Grande (eds), Science and History: Studies in Honor of Edward Rosen, Wrocław: Wydawnictwo Polskiej Akademij Nauk, 1978, pp. 157-185; Id., 'The Origins of the Theorica Planetarum', Journal for the History of Astronomy 12 (1981), pp. 113-123; Id., 'The Theorica Planetarum and Its Progeny', in Graziella Federici Vescovini and Francesco Barocelli (eds), Filosofia, scienza e astrologia nel Trecento europeo: Biagio Pelacani Parmense, Padua: Il poligrafo, 1992, pp. 53-78; James Steven Byrne, 'The Stars, the Moon, and the Shadowed Earth: Viennese Astronomy in the Fifteenth Century', PhD Diss., Princeton University, 2007, pp. 110-155; Id., 'The Mean Distances of the Sun and the Commentaries on the Theorica Planetarum', Journal for the History of Astronomy 42 (2011), pp. 205-221.

5 The Theorica planetarum was incorporated in full in the 'long recension' of Michael Scot's Liber introductorius (lib. I = Liber quatuor distinctionum), as found in MS Munich, Bayerische Staatsbibliothek, Clm 10268, fols 74rb-77va, yet this copy only dates from c. 1320 and may have been augmented by later interpolations. The insertion is treated as authentic by Glenn M. Edwards, 'The Two Redactions of Michael Scot's Liber Introductorius', Traditio 41 (1985), pp. 329340, at pp. 339-340. A twelfth-century origin of the standard Theorica planetarum has been defended by Graziella Federici Vescovini, 'Michel Scot et la Theorica Planetarum Gerardi', Early Science and Medicine 1 (1996), pp. 272-282; Ead., 'Autour de la Theorica planetarum Gerardi', in Donatella Nebbiai-Dalla-Guarda and Jean-François Gesnet (eds), Du copiste au collectionneur: mélanges d'histoire des textes et des bibliothèques en l'honneur d'André Vernet, Turnhout: Brepols, 1998, pp. 169-174, but I find her argument unpersuasive.

6 On the diagrams included in the standard Theorica planetarum, see Kathrin Müller, Visuelle Weltaneignung: Astronomische und kosmologische Diagramme in Handschriften des Mittelalters, Göttingen: Vandenhoeck \& Ruprecht, 2008, pp. 253-271. 
angles involved in the computation of true longitudes. In striking contrast to the standard Theorica planetarum, which refers to its diagrams in a very generic fashion (e.g., sicut patet in figura), the Lmp provides descriptions that are detailed enough to serve as instructions for how to draw these diagrams without an exemplar. Also, while the diagrams included in the pseudo-Gerardian Theorica and a myriad of other medieval astronomical manuscripts opt for a purely geometrical representation of planetary motions, the diagrams in the Lmp depict the physical orbs that encase and move the individual planets. The orb of the Sun, for instance, is described as being bounded by an outer and an inner surface marked by circles FGHI and KLMN, which are both concentric to the orb of the zodiac, ABCD (1l. 6572). Within the orb of the Sun lies a smaller orb, eccentric to the main one, whose surface carries the body of the Sun itself. In the diagram, this eccentric orb is represented by the circle FOMP centred on point Q. It touches the outer and inner surface of the Sun's orb at points F and M, which serve as the model's apogee and perigee (11. 72-79; see Fig. 1). While the deferent orb of the Sun is here reduced to a circle, the deferent orb in the diagrams for the Moon, Mercury, and the remaining planets each has a width that corresponds to the diameter of the epicycle that moves inside it (see Figs. 2-4).

The Lmp's commitment to solid orbs is cloaked only slightly by its indiscriminate use of the term circulus to refer to both circles and orbs. For instance, in 1l. 50-52 the text speaks of the 'outer' and 'inner' surface of a planetary circulus, the space between which defines the spissitudo ('thickness') of the circulus in question. Likewise, in 11. 132-136 the Moon is assigned a circulus circulo signorum similis with two surfaces, outer and inner, the space between which contains a circulus excentricus, 'which is placed in a sloping manner within [its] thickness' ('qui declive positus est in spissitudine circuli lune similis circulo signorum'). It goes without saying that this sort of statement makes sense only if circulus is understood to mean a three-dimensional orb. One conjecture worth making is that the ambiguity encountered in the $\mathrm{Lmp}$ with regard to circulus is due to the way an equivalent Arabic word was used in one of the source texts that underlie it. The most obvious candidate for the word in question is falak, which retains a double meaning of 'circle' and 'orb' in the eleventh-century Maqäla fì hay'at al-älam (On the Configuration of the World), a work often attributed to the famous astronomer and mathematician Abū 'Alī al-Hasan ibn al-Haytham (d. c. 1040), but more likely to have been written by his contemporary and namesake, the philosopher Muhammad ibn al-Haytham. ${ }^{7}$

\footnotetext{
See Y. Tzvi Langermann (ed. and trans.), Ibn al-Haytham's on the Configuration of the World, New York: Garland Publishing, 1990, repr. London: Routledge, 2016. Plausible arguments against the traditional ascription are provided in Roshdi Rashed, 'The Configuration of the Universe: A Book by al-Hasan ibn al-Haytham?', Revue d'histoire des sciences 60 (2007), pp. 47-63.
} 
In Ibn al-Haytham's text, the term falak in used indiscriminatly to denote circles or solid orbs, although the main focus is clearly on the three-dimensional quality of the planetary models and hence on orbs, which are described in ways similar to what we find in the $L m p .{ }^{8}$ For the total orb that contains within it the kinematic components of a given planet, Ibn al-Haytham uses the expression al-falak almumaththal, i.e. the 'assimilated sphere' in the sense of it being concentric to the sphere of the universe. It may be possible to discern in this term the source behind the expression circulus similis circulo signorum, which appears repeatedly in the Lmp (ll. 49-50, 68, 132-136, 141-143, 151-152, 217-218, 295, 381). The only twelfthcentury Latin translation of Ibn al-Haytham's On the Configuration of the World that has been identified so far is the one woven into the Liber Mamonis written by Stephen of Pisa (fl. 1127) in the Crusader state of Antioch. ${ }^{9}$ Stephen made a free translation of nearly the complete text of the On the Configuration and added to it his own commentary. It must be underlined, however, that the Liber Mamonis survives only in a single copy and there are as yet no signs that the text was used by other Latin authors in the twelfth century or later. ${ }^{10}$

Whatever the immediate source behind its elaborate diagrams and statements about the surfaces and thickness of different circuli, the Lmp provides us with valuable evidence to show that planetary models composed of multipart physical orbs were already known in twelfth-century Christian Europe. This is not a point generally recognized in the modern literature. Most studies trace Latin awareness of this type of model no further back than to Roger Bacon, who in or around 1267/68 used the expression quaedam imaginatio modernorum to introduce the theory in question. ${ }^{11}$ Bacon does not identify any source for this imaginatio, but his

8 Y. Tzvi Langermann, 'A Note on the Use of the Term Orbis (Falak) in Ibn al-Haytham's Maquālah fi hay'at al-älam', Archives internationales d'histoire des sciences 32 (1982), pp. 112-113, and Id., Ibn alHaytham's on the Configuration of the World, pp. 5-7. On Ibn al-Haytham's orb models, see Willy Hartner, 'The Mercury Horoscope of Marcantonio Michiel of Venice: A Study in the History of Renaissance Astrology and Astronomy', Vistas in Astronomy 1 (1955), pp. 84-138, at pp. 122-127; Michel-Pierre Lerner, Le monde des sphères, vol. I, Genèse et triomphe d'une représentation cosmique, Paris: Les Belles Lettres, 1996, pp. 92-98.

9 See most recently Dirk Grupe, 'Stephen of Pisa's Theory of the Oscillating Deferents of the Inner Planets (1h. 12 ${ }^{\text {th }}$ C.)', Archive for History of Exact Sciences 71 (2017), pp. 379-407, with references to further literature.

10 The copy in question is MS Cambrai, Bibliothèque (Médiathèque) municipale, 930. I have seen no signs that the wording of this translation had any influence on the $\operatorname{Lmp}$.

11 The pertinent passages are edited in Pierre Duhem, Un fragment inédit de l'Opus tertium de Roger Bacon: précédé d'une étude sur ce fragment, Quaracchi: Ex Typographia Collegii S. Bonaventurae, 1909, pp. 125-131; Roger Bacon, De celestibus, ed. in Robert Steele, Opera hactenus inedita Rogeri Baconi, vol. IV, Oxford: Clarendon Press, 1913, pp. 437-443. For examples among a multitude of modern accounts, see Duhem, Le système, pp. 428-442; Reuven S. Avi-Yonah, 'Ptolemy vs al-Bitruji: A Study of Scientific Decision-Making in the Middle Ages', Archives internationales d'histoire des sciences 35 (1985), pp. 124-147, at p. 135; Henri Hugonnard-Roche, 'Problèmes méthodologiques dans l'astronomie au début du XIVe siècle', in Gad Freudenthal (ed.), Studies on Gersonides: A 
use of technical vocabulary suggests he may have seen a Latin translation of Ibn al-Haytham's On the Configuration of the World with the title Liber Aboali ibin Hertam, which survives in a late-thirteenth century manuscript. ${ }^{12}$ Dag Hasse has recently argued that the Latin vocabulary in this translation points to it having been made by Michael Scot (d. in or after 1235) ${ }_{1}^{13}$ which would confirm a thirteenth- rather than a twelfth-century origin.

An author contemporaneous with Michael Scot who showed some familiarity with orb models was William the Englishman (or William of Marseille), whose Astrologia of 1220 immediately follows upon the Lmp in $F$ (fols $111 \mathrm{vb}-124 \mathrm{vb}$ ). It is also found in the composite codex $E$ (fols $1 \mathrm{r}-21 \mathrm{r}$ ), in a neat copy made late in the thirteenth or early in the fourteenth century. ${ }^{14}$ At the end of a Theorica-style account of the motions of the Moon, William points out that 'each planet by its nature has a thick and solid sphere' and goes on to detail how the distance between the inner and outer surface of each sphere (spera) was determined by the apogees

Fourteenth-Century Jewish Philosopher-Scientist, Leiden: Brill, 1992, pp. 55-70, at pp. 62-64; Hugonnard-Roche, 'Contribution arabe à la cosmologie occidentale latine', in Cieli e terre nei secoli XI-XII: orizzonti, percezioni, rapporti, Milan: Vita e pensiero, 1998, pp. 89-109, at pp. 106-108; Edward Grant, Planets, Stars, and Orbs: The Medieval Cosmos, 1200-1687, Cambridge: Cambridge University Press, 1994, pp. 277-281; Id., 'Celestial Motions in the Late Middle Ages', Early Science and Medicine 2 (1997), pp. 129-148, at pp. 136-138; Lerner, Le monde des sphères, pp. 115-118; Byrne, 'The Stars, the Moon, and the Shadowed Earth', pp. 66-78; Edith Dudley Sylla, 'The Status of Astronomy as a Science in Fifteenth-Century Cracow: Ibn al-Haytham, Peurbach, and Copernicus', in Rivka Feldhay and F. Jamil Ragep (eds), Before Copernicus: The Cultures and Contexts of Scientific Learning in the Fifteenth Century, Montreal \& Kingston: McGill-Queen's University Press, 2017, pp. 45-78, at pp. 50-52.

12 MS Madrid, Biblioteca nacional de España, 10059, fols 37r-50r. The text is transcribed in full in José M. ${ }^{a}$ Millás Vallicrosa, Las traducciones orientales en los manuscritos de la Biblioteca Catedral de Toledo, Madrid: CSIC, 1942, pp. 285-312. Bacon's use of this translation was recently suggested by Dag Nikolaus Hasse, 'Averroes' Critique of Ptolemy and Its Reception by John of Jandun and Agostino Nifo', in Paul J. J. M. Bakker (ed.), Averroes' Natural Philosophy and Its Reception in the Latin West, Leuven: Leuven University Press, 2015, pp. 69-88, at p. 83.

13 Dag Nikolaus Hasse, 'Stylistic Evidence for Identifying John of Seville with the Translator of Some Twelfth-Century Astrological and Astronomical Texts from Arabic into Latin on the Iberian Peninsula', in Charles Burnett and Pedro Mantas-España (eds), 'Ex Oriente Lux': Translating Words, Scripts and Styles in Medieval Mediterranean Society, Córdoba: UCOPress, 2016, pp. 19-43, at p. 37. On the Configuration of the World was translated into Castilian during the reign of King Alfonso X (1252-1284), presumably during the 1260 s or 1270s. A Latin version of this lost Castilian text survives in a single manuscript edited by José Luis Mancha, 'La version alfonsi del Fì hay'at al-ālam (De configuratione mundi) de Ibn al-Haytham (Oxford, Canon misc. 45, ff. 1r-56r)', in Mercè Comes, Honorino Mielgo and Julio Samsó (eds), 'Ochava espera' y 'astrofísica': textos y estudios sobre las fuentes árabes de la astronomía de Alfonso X, Barcelona: Instituto 'Millás Vallicrosa' de Historia de la Ciencia Árabe, 1990, pp. 133-207. Another translation of the text appears in MS Lüneburg, Ratsbücherei, Miscell. D 2 ${ }^{\circ} 13$, fols 108va-119vb (s. XIV ${ }^{2 / 2}$ ).

14 Other copies of this text appear in MSS Erfurt, Universitäts- und Forschungsbibliothek, CA $2^{\circ} 394$, fols 136ra-140vb; Seville, Biblioteca Capitular Colombina, 5-1-25, fols 1r-33r, 110v-128v (two copies; not seen); Vienna, Österreichische Nationalbibliothek, 5311, fols 42ra-52v. 
and perigees of the eccentric deferent and epicycle. ${ }^{15}$ A more fleshed out account of this basic idea had previously already been given in the $\operatorname{Lmp}$, the existence of which calls us to revise our timeline of 'physicalized' planetary models in medieval Europe, at least in so far as concerns texts in the Theorica planetarum genre. Edith Dudley Sylla recently concluded an article on this topic by stating that "works called theorica planetarum evolved from describing the motions of the planets using mathematical lines to describing them, at least in part, using physical orbs. ${ }^{16} \mathrm{Her}$ account of the introduction of these physical orbs into the Latin astronomical discussion puts most of its emphasis on Ibn al-Haytham's On the Configuration of the World, which according to Sylla 'was transmitted to Latin-speaking Europe at the latest by the end of the thirteenth century'. ${ }^{17}$ Sylla here ignores the aforementioned Liber Mamonis, but her overall chronology of events is also called into question by the Lmp, which shows us that the evolution of the Theorica planetarum genre was not so straightforward. Thanks to the Lmp, it is now clear that a Theorica-type text describing Ptolemy's models in terms of multipart physical orbs already circulated in the third quarter of the twelfth century and hence prior to the popular Theorica planetarum of pseudo-Gerard of Cremona.

It should be underlined that this holds true not just for textual descriptions, but also for diagrammatic depictions of the multipart orbs in question. While the extant Arabic manuscripts of Ibn al-Haytham's On the Configuration of the World are devoid of such diagrams, a full set of them appears in the aforementioned thirteenth-century translation into Latin (Liber Aboali ibin Hertam). Similar diagrams became a recurrent feature of late medieval Latin works such as the fourteenth-century revision of the common Theorica planetarum ascribed to Walter Bryt or the Theoricae novae planetarum by Georg Peuerbach, which go back to lectures first held in 1454 at the University of Vienna. ${ }^{18}$ In light of a recent and not

$15 \quad E$ (fol. 7v): 'Nec pretereundum est quemlibet planetam speram habere spissam et solidam in sui natura que se commetitur secundum sui quantitatem figure firmamenti et est concentralis mundo et eius spissitudo est tanta ut sufficiat continere excentricitatem et semidiametrum epicicli et semidiametrum corporis planete. Unde cum centrum epicicli fuerit in auge excentrici et corpus planete in auge epicicli, tangit corpus planete superiorem superficiem spere. Cum autem centrum epicicli fuerit in oppositione augis excentrici et corpus planete in oppositione augis epicicli, tangit corpus planete inferiorem superficiem spere. Et spera cuiuslibet planete secundum ordinem planetarum contingua est spere alterius.' This passage was first noted by Duhem, Le système du monde, pp. 289-290. See also Michael H. Shank, 'Rings in a Fluid Heaven: The Equatorium-Driven Physical Astronomy of Guido de Marchia (fl. 1291-1310)', Centaurus 45 (2003), pp. $175-203$, at pp. $177-178$. Sylla, 'The Status of Astronomy', p. 76.

Ibid., p. 46.

18 Olaf Pedersen, 'The Problem of Walter Brytte and Merton Astronomy', Archives internationales d'histoire des sciences 36 (1986), pp. 227-248, at p. 242; E. J. Aiton, 'Peurbach's Theoricae Novae Planetarum: A Translation with Commentary', Osiris, $2^{\text {nd }}$ ser., 3 (1987), pp. 4-43; Isabelle Pantin, 'The First Phases of the Theoricae Planetarum Printed Tradition (1474-1535): The Evolution of a 
particularly well-substantiated attempt to explain Peuerbach's use of orb diagrams as the heritage of later Arabic text such as al-Jaghminnis early-thirteenth century Mulakhkhas fi 'ilm al-hay'a al-basița, ${ }^{19}$ it may not be unimportant to draw scholarly attention to the Lmp, which offers grounds to believe that Peuerbach simply continued a pictorial tradition that had existed in the Latin world for three centuries by the time he composed his Theoricae novae.

\section{Date and place of origin}

My earlier claim that the Lmp was written in the third quarter of the twelfth century is obviously in need of some justification, since it does not follow straightforwardly either from the text itself or from its manuscript transmission. of the nine complete or partial copies, most date from the period 1250-1350 and present the text without attribution. One chronological outlier is the copy in $R$, which is untitled and anonymous, but might go back to the beginning of the thirteenth century. Another noteworthy exception is $D$, a copy from the midfifteenth century whose colophon reads Explicit Lincolniensis in Theorica spere (fol. 143r). This must be interpreted as an attribution of the preceding text to Robert Grosseteste, Bishop of Lincoln from 1235 to 1253, whose Compotus treatise from the 1220 s comes immediately before the Lmp in manuscripts $F$ (fols $87 \mathrm{v}-107 \mathrm{r}$, s. XIV ${ }^{1 / 2}$ ) and $V$ (fols $44 \mathrm{ra}-62$ r, s. XIII ${ }^{2 / 2}$ ). The only other copy to attach something like an author's name to the Lmp is $P$ (s. XIII/XIV), where a marginal note from the hand of the main scribe identifies our text as De motibus planetarum secundum Abraham (fol. 418v). This calls to mind the multifaceted Jewish scholar Abraham Ibn Ezra (c.1089-c.1161), who began to exert a seminal influence on Latin astronomy and astrology upon his departure from his native Spain in $c .1140 .{ }^{20}$ His influence is

Genre Observed through its Images', Journal for the History of Astronomy 43 (2012), pp. 3-26; Michela Malpangotto, 'Les premiers manuscrits des Theoricae novae planetarum de Georg Peurbach: présentation, description, évolution d'un ouvrage', Revue d'histoire des sciences 65 (2012), pp. 339380; Malpangotto, 'The Original Motivation for Copernicus's Research: Albert Brudzewo's Commentariolum super Theoricas novas Georgi Purbachii', Archive for History of Exact Sciences 70 (2016), pp. 361-411.

19 Sally P. Ragep, 'Fifteenth-Century Astronomy in the Islamic World', in Feldhay and Ragep (eds), Before Copernicus: The Cultures and Contexts of Scientific Learning, pp. 143-161, at pp. 157-158.

20 For Abraham Ibn Ezra and his influence on twelfth-century Latin astronomy, see Shlomo Sela, 'Contactos científicos entre judíos y cristianos en el siglo XII: el caso del Libro de las tablas astronómicas de Abraham Ibn Ezra en su versión latina y hebrea', Miscelánea de Estudios Árabes y Hebraicos, Sección de Hebreo, 45 (1996), pp. 185-222; Id., 'Algunos puntos de contacto entre el Libro de las tablas astronómicas en su versión latina y las obras literarias hebreas de Abraham Ibn Ezra', Miscelánea de Estudios Árabes y Hebraicos, Sección de Hebreo, 46 (1997), pp. 37-56; Id., 'Origins and Transmission of Liber Abraham Iudei de nativitatibus: A New Appraisal Based on the Scrutiny of the Available Manuscripts and Other Sources', Revue des études juives (forthcoming); Julio Samsó, 'El procés de la transmissió científica al nord-est de la península Ibèrica al segle XII: els textos 
clearly detectable in a brief twelfth-century text with the incipit Inter omnes recte philosophantes, which dates itself to AD 1169 and follows immediately after the Lmp in manuscript $P$ (fols $422 \mathrm{v}-423 \mathrm{v}$ ). Large parts of this anonymous composition were apparently drawn from a much longer treatise, starting Ptolomeus et multi sapientum (hereafter shortened to Ptolomeus), which survives in a manuscript from the Meuse region, copied in 1175 or soon thereafter. ${ }^{21}$

At its core, Ptolomeus is a multi-part commentary written to accompany a set of astronomical tables for the meridian of Pisa that Ibn Ezra had adapted from the tenth-century tables of al-Șüfi. ${ }^{22}$ Although there are several Latin works dealing with these Pisan Tables, Ptolomeus is the only one to reveal their date of composition, claiming that the tables were put together in AD $1143 .{ }^{23}$ To judge from an example involving ' 1144 completed [years] before the present year', the text itself was written not very long thereafter, in $\mathrm{AD} 1145 .{ }^{24}$ Both the early date and the level of detail on display would make it tempting to see in Ptolomeus a work by Abraham Ibn Ezra himself, were it not for the occasional reference to 'our Lord

llatins', in Joan Vernet and Ramon Parés (eds), La ciència en la història dels Països Catalans, vol. I, Dels àrabs al Renaixement, Valencia: Institut d'Estudis Catalans, 2004, pp. 269-296, at pp. 286-293; Id., 'Dixit Abraham Iudeus: algunas observaciones sobre los textos astronómicos latinos de Abraham ibn 'Ezra', Iberia Judaica 4 (2012), pp. 171-200; Renate Smithuis, 'Science in Normandy and England under the Angevins: The Creation of Abraham Ibn Ezra's Latin Works on Astronomy and Astrology', in Giulio Busi (ed.), Hebrew to Latin, Latin to Hebrew: The Mirroring of Two Cultures in the Age of Humanism, Turin: Aragno, 2006, pp. 23-60.

21 See MS Cambridge, Fitzwilliam Museum, McClean 165, which is described in Nigel Morgan and Stella Panayotova, A Catalogue of Western Book Illumination in the Fitzwilliam Museum and the Cambridge Colleges, pt. I, vol. II, London: Harvey Miller Publishers, 2009, pp. 12-13. The text of Ptolomeus begins on fol. $67 \mathrm{r}$ and continues at least until fol. $76 \mathrm{v}$. Of the portions that follow until fol. 79r, some may be later accretions. The parts that correspond most closely to Inter omnes recte philosophantes in P appear on fol. 68r-v. Some of the following sections of Ptolomeus also survive in MS Oxford, Bodleian Library, Selden supra 26, fols $122 \mathrm{r}-129 \mathrm{v}\left(\mathrm{s} . \mathrm{XIII}^{\mathrm{in}}\right)$. The text here starts at the sub-incipit Tabulas compositurus hoc ordine procedes (fol. 68v in McClean 165). It breaks off prematurely at tantum est remotus quanta fuit differentia partis (fol. 72v in Mcclean 165) due to a loss of pages at the end of the codex.

22 On the astronomical tables and related texts associated with Abraham Ibn Ezra, see Raymond Mercier, 'The Lost Zij of al-Ṣūfĩ in the Twelfth-Century Tables for London and Pisa', in Studies on the Transmission of Medieval Mathematical Astronomy, Aldershot: Ashgate, 2004, ch. VIII; John D. North, 'The Longitudes of Winchester', Cahiers de l'Institut du Moyen-Âge Grec et Latin 73 (2002), pp. 13-20; Fritz S. Pedersen, 'Astronomical Tables for Pisa in Ms. København K.B., GkS 277, Fol.', Renaessanceforum 3 (2007), pp. 1-16, and the literature cited in n. 20 above.

23 MS Cambridge, Fitzwilliam Museum, McClean 165, fol. 70v: 'Tabule autem nostre, composite scilicet anno Christi 1143, habent secundum annum bissextilem.'

24 MS Cambridge, Fitzwilliam Museum, McClean 165, fol. 70r: '...et incipere a quoto anno volueris, utpote a 1144 completis ante presentem annum.' Cf. Raymond Mercier, 'Astronomical Tables in the Twelfth Century', in Charles Burnett (ed.), Adelard of Bath: An English Scientist and Arabist of the Early Twelfth Century, London: The Warburg Institute, 1987, pp. 87-118, at p. 111, who wrongly reports this passage as mentioning ' 1149 (complete)'. The same error is repeated in Smithuis, 'Science in Normandy', p. 33. 
Jesus Christ', ${ }^{25}$ which indicates that the author was a Christian. It is still perfectly possible, however, that Ptolomeus was the product of a Christian student or collaborator of Ibn Ezra, who presented the Jewish master's doctrine in his own words. A well-known precedent for this modus operandi is the treatise De Dracone by Walcher of Malvern (1120), which according to its own title preserved the Sententia Petri Ebrei, that is, the astronomical doctrine of Walcher's Jewish teacher Petrus Alfonsi. ${ }^{26}$ The expression secundum Abraham used in $P$ for the title of the Lmp may have been intended to describe something similar-a text 'inspired by' or 'following the doctrines of', rather than 'written by' Abraham.

A comparison between the Lmp and Abraham Ibn Ezra's own Latin introduction to the Pisan Tables, the so-called Liber de rationibus tabularum, ${ }^{27}$ does not reveal much by way of doctrinal influence. At most, one can point to the technical vocabulary used in discussing planetary equations. The $\operatorname{Lmp}$ is consistent in referring to the equation of centre of all planets as the equatio puncti and the equation of anomaly as the equatio portionis. This façon de parler is not too common in Latin astronomical texts, but it does characterize the corpus of extant texts connected to Ibn Ezra's Tables of Pisa. ${ }^{28}$

The one text within this corpus whose vocabulary converges most closely with the Lmp is the aforementioned Ptolomeus, which offers an in-depth account of planetary motions in the manner of a Theorica planetarum..$^{29}$ After dealing with stations and retrogradations as well as planetary latitudes, the text goes on to provide a series of definitions pertaining to the computation of true longitudes. It is worth noting that this section begins with a remark about the outer and inner surface of the circulus similis circulo signorum, which is reminiscent of some of the language used in the Lmp and indicates that the author of Ptolomeus thought of his planetary models as being composed of physical orbs. ${ }^{30}$ More significant for our

25 MS Cambridge, Fitzwilliam Museum, McClean 165, fol. 68r: 'Sunt autem inter annos Alexandri et annos domini nostri Ihesu Christi 311 anni'. See also Ibid., fol. 70r.

26 For an edition, translation, and commentary on this text, see C. Philipp E. Nothaft, Walcher of Malvern: 'De lunationibus' and 'De Dracone', Turnhout: Brepols, 2017, pp. 46-55, 194-217, 271-297.

27 See the edition of this work in José M. ${ }^{a}$ Millás Vallicrosa, El libro de los fundamentos de las Tablas astronómicas de R. Abraham Ibn Ezra, Madrid: CSIC, 1947.

28 See, e.g., the Liber de rationibus tabularum, ed. Millás Vallicrosa, El libro, pp. 102-103, 112. See also the Tractatus Magistri Habrahe de tabulis planetarum in MS London, British Library, Arundel 377, fols 56va-63ra (s. XII/XIII), and the Liber de equationibus planetarum secundum meridiem Pissanorum in MS Berlin, Staatsbibliothek, lat. fol. 307 , fol. $27 \mathrm{r}-\mathrm{v}\left(\mathrm{s} . \mathrm{XII}^{2 / 2}\right)$. A similar vocabulary is used in a set of canons for the Toledan Tables starting Scito quod annus lunaris, which will be discussed in section IIIb below.

29 MS Cambridge, Fitzwilliam Museum, McClean 165, fols 71r-76v. On the idiosyncratic lunar theory expounded in this section, see the remarks in Pedersen, 'A Twelfth-Century Planetary Theorica', pp. 214-215.

30 MS Cambridge, Fitzwilliam Museum, McClean 165, fol. 75v: 'Circulus augis est superior superficies circuli similis circulo signorum. Circulus oppositi auge est inferior eiusdem superficies.' 
purposes are the text's definitions of the individual planetary equations, which in several cases pertaining to the longitude of the Moon are close to identical to those included in the Lmp:

\begin{abstract}
Lmp (1l. 178-189):
Equatio puncti est distantia capitum duarum linearum in superiori circumferentia epicicli, quarum una a centro terre et alia a centro excentrici circuli exeunt per centrum epicicli.
\end{abstract}

Que equatio super portionem simplicem est addenda, si longitudo duplex est minor CLXXX gradibus, id est VI signis, vel minuenda $a b$ eadem, si est maior. Que portio simplex post augmentum vel diminutionem equationis puncti 'portio coequata' nominatur.

Equatio diversitatis diametri circuli brevis est distantia capitum duarum linearum in superiori circumferentia epicicli, quarum una exit a centro terre et alia a centro predicto, quod est inter terram et longitudinem propiorem excentrici, per centrum epicicli.

Minuta proportionum sunt numeri proportionales quorum proportionalitate cum LX accipitur illud quod debet aggregari equationi portionis de equatione diversitatis diametri circuli brevis.

Lmp (1l. 194-197, 199-200):

Equatio vero portionis est distantia capitum duarum linearum in circulo signorum exeuntium a centro terre, quarum una exit per centrum epicicli, alia vero per corpus lune in circumferentia epicicli transit. [...]

Que equatio portionis equata debet aggregari medio cursui lune, si portio equata fuerit maior CLXXX gradibus, id est VI signis, vel minui, si minor.

\section{Ptolomeus: ${ }^{3}$}

Equatio puncti est arcus epicicli inter duas lineas ad eius centrum sectantes se, quarum una exit a centro zodiaci, altera centro ecentrici.

Que equatio super simplicem portionem est addenda, si longitudo duplex minor est CLXXX gradus, que si maior, minuenda. Hec portio simplex post augmentum vel diminutionem equationis puncti ‘coequata' dicitur.

Equatio diversitatis diametri circuli brevis est arcus epicicli inter duas lineas in circulo brevi sese apud centrum intersecantes, quarum una exit a centro zodiaci, altera autem a puncto ad quem fit declinatio diametri circuli brevis extra conventum et oppositionem. [...]

Minuta proportionalia sunt numeri proportionales quorum proportionalitate cum LX accipitur illud quod debet aggregari equationi portionis de equatione diversitatis diametri circuli brevis.

Equatio portionis est arcus zodiaci inter duas lineas exeuntes a centro zodiaci, altera per centrum lune, altera per centrum epicicli. [...]

Que equatio post augmentum debet aggregari medio cursui lune, si equata portio fuerit maior 180 gradus, vel minui, si minor, et habetur locus lune in circulo signorum.

31 MS Cambridge, Fitzwilliam Museum, McClean 165, fol. 76r. 
It can be seen that the two texts share identical expressions not only for the Moon's equations of centre and anomaly, but also for the increment necessitated by the variation of epicyclic diameter, here referred to as the equatio diversitatis diametri circuli brevis. In the case of the Lmp (1l. 184-187), this equatio is introduced as the distance of the heads of two lines [located on] the upper circumference of the epicycle that go through the centre of the epicycle, one from the centre of the Earth and the other from the aforementioned centre, which lies between the Earth and the perigee of the eccentric [circle]'. Earlier on in the same discussion (1l. 174176), the Moon's mean anomaly (portio lune simplex) is defined as the distance on the circumference of the epicycle between the body of the planet and the epicyclic apogee, as measured 'from a particular centre that lies between the perigee of the excentric [circle] and the centre of the Earth'. This is clearly the 'aforementioned centre' referenced somewhat later in the text as part of the definition of the equatio diversitatis diametri circuli brevis (1l. 185-187). In the corresponding diagram (Fig. 2), this centre is marked by point Q-what is sometimes known as Ptolemy's prosneusis point. A line that goes from this point through the centre of the epicycle will by definition intersect with the epicycle's upper circumference at the mean apogee, whereas the line that goes from the centre of the Earth through to the centre of the epicycle will identify the true apogee. It follows that in trying to define the diameter-increment of the epicycle, Ptolomeus and the Lmp instead give the correct definition for the equation of centre, or equatio puncti, which is the one that concerns the angle between the mean and true epicyclic apogee. In introducing the latter, both texts again offer a very similar definition, which in each case erroneously replaces the 'aforementioned centre' with the centre of the excentric deferent, which makes no sense in the context of Ptolemy's second lunar model.

Since the account of planetary equations in Ptolomeus is significantly more detailed than that provided in the $L m p{ }^{32}$ it would appear that the Lmp's mistakes in this area were inspired by the former text, not the other way around. If we accept this line of influence, we automatically obtain AD 1145, the annus praesens of Ptolomeus, as a terminus post quem for the composition of the Lmp. As for the terminus ad quem, a valuable hint can be gleaned from the text's treatment of the motion of the sphere of the fixed stars, which deviates somewhat from the standard Ptolemaic theory. Rather than depicting precession as a linear and unidirectional motion towards the east at a rate of $1^{\circ}$ per century, our text claims that the sphere of fixed stars alternates between periods of eastward and westward motion, with a total amplitude of $8^{\circ}$ (1l. 43-46). With regard to the period of

32 This is true in particular for the remaining planets, but also for the Moon, where Ptolomeus's discussion of the numeri proportionales used in calculating the diameter-increment (cf. 1l. 189-194 in the $\operatorname{Lmp}$ ) includes an account of the modus operandi followed by the makers of the Toledan Tables (Arzacellus and Abenchahant). MS Cambridge, Fitzwilliam Museum, McClean 165, fol. 76r. 
eastward or 'forward' motion, we are told that the eighth sphere moves from the beginning of Aries to $22^{\circ}$ Pisces (1l. 44-45: 'movetur ante, id est versus orientem, VIII gradibus usque ad XXII gradum Piscium'). In order to makes sense of this statement, $22^{\circ}$ Pisces must be interpreted as a sidereal degree on the eighth sphere, which comes to align with tropical $0^{\circ}$ Aries (the vernal point) as the eighth sphere moves $8^{\circ}$ to the east. Afterwards, the sidereal equivalent of $0^{\circ}$ Aries will return to start, i.e. to tropical $0^{\circ}$ Aries (1. 45: 'et inde revertitur'), and continue to move westward until tropical $0^{\circ}$ Aries coincides with sidereal $8^{\circ}$ Aries (1l. 45-46: 'et movetur iterum ab initio Arietis retro, id est versus occidentem, totidem gradibus, id est VIII'). This is then followed by another reversal of direction to bring the eighth sphere back to its starting point (1. 46: 'et rursum versus orientem').

The notion according to which the sphere of fixed stars undergoes back-andforth shifts of $8^{\circ}$ crops up in a number of Latin texts written or translated during the twelfth century, but most of these restrict this back-and-forth motion to a band of $8^{\circ}$ (i.e., from $0^{\circ}$ Aries to $22^{\circ}$ Pisces and back to $0^{\circ}$ Aries) without hinting at a total amplitude of $2 \times 8^{\circ}=16^{\circ}$ of the kind assumed in the $L m p^{33}$ Among the exceptions is the aforementioned treatise Ptolomeus, which credits the Indians with a theory that allows the heads of Aries and Libra to swing 'to the right and to the left' (versus dextram et versus sinistram) by $8^{\circ}$, thereby accounting for changes in the length of the tropical year. ${ }^{34}$ What Ptolomeus does not do in the relevant passage is refer to the sphere of fixed stars as the circulus accessionis et recessionis (1. 47) on account of its bidirectional motion. An expression of this type instead crops up in the Compotus of Roger of Hereford, a work securely datable to 1176. In a manner strikingly similar to the Lmp, Roger attributes to certain unspecified 'philosophers' the opinion that the starry sphere can move by $8^{\circ}$, such that it goes from $0^{\circ}$ Aries to $22^{\circ}$ Pisces. Rather than proceeding to describe the ensuing motion in a westerly direction from $22^{\circ}$ Pisces to $8^{\circ}$ Aries, Roger concludes with a motion of $8^{\circ}$ 'against

33 See, e.g., ch. 52 of al-Battānī, De motu stellarum, Nuremberg: Petreius, 1537, fol. 80v; Abū Ma shar, De magnis coniunctionibus (2.8.36), ed. Keiji Yamamoto and Charles Burnett, vol. II, Leiden: Brill, 2000, pp. 99-100; John of Spain, Sententie de diversis libris excerpte, ed. José M. ${ }^{a}$ Millás Vallicrosa, 'Una obra astronómica desconocida de Johannes Avendaut Hispanus', Osiris 1 (1936), pp. 451-475, at p. 467; Abraham Ibn Ezra, Liber de rationibus tabularum, ed. Millás Vallicrosa, El libro de los fundamentos, p. 77, 1. 8; ps.-Aristotle, De causis proprietatum et elementorum, ed. in Stanley Luis Vodraska, 'Pseudo-Aristotle, De causis proprietatum et elementorum: Critical Edition and Study', PhD Diss., University of London, 1969, pp. 151-152 (ch. 9). The ultimate source behind these statements is Theon of Alexandria's Little Commentary on the Almagest. See Anne Tihon (ed.), Le 'Petit commentaire' de Théon d'Alexandrie aux Tables faciles de Ptolémée, Vatican City: Biblioteca Apostolica Vaticana, 1978, pp. 236-237, and Nothaft, Walcher of Malvern, pp. 285-286.

34 MS Cambridge, Fitzwilliam Museum, McClean 165, fols $67 \mathrm{v}-68 \mathrm{r}$. A variation by $8^{\circ}$ in both directions ('ante et retro') is also alluded to in the Liber ysagogarum Alchorismi, ed. Bruce George Dickey, 'Adelard of Bath: An Examination Based on Heretofore Unexamined Manuscripts', PhD Diss., University of Toronto, 1982, p. 328. See Nothaft, Walcher of Malvern, p. 290. 
the east'. The result reads very much like a contraction of the corresponding passage in the Lmp.

\begin{abstract}
Lmp (1l. 37-39, 43-47):
Sol itaque secundum auctoritatem philosophorum duos habet motus, quorum primus est essentialis ab occidente in orientem in suo excentrico circulo unaquaque die LIX minutis et VIII secundis.

[...] Et nota quod octava spera ab initio Arietis movetur ante, id est versus orientem, VIII gradibus usque ad XXII gradum Piscium, et inde revertitur et movetur iterum ab initio Arietis retro, id est versus occidentem, totidem gradibus, id est VIII, et rursum versus orientem. Unde 'circulus accessionis et recessionis' dicitur.
\end{abstract}

Roger of Hereford: ${ }^{35}$

Dicunt enim philosophi, quod sphaera stellarum fixarum movetur, sed in nongentis annis cum caelo, in totidem contra celum. Unde dicitur sphaera accessionis et recessionis. VIII enim gradus movetur sic, ut a primo Arietis usque ad XXII ${ }^{\text {um }}$ Piscium et inde VIII contra orientem. Et haec movet secum alias sphaeras ut solis.

At first glance, of course, the similarity between the two passages is undermined by the way the Lmp assumes, based on the authority of the philosophi, that the sphere of fixed stars moves at a rate of $1^{\circ}$ per century $(11.40,43)$. This would imply that the entire cycle of accessio et recessio takes $4 \times 800=3200$ years to complete, whereas Roger of Hereford ascribes to the philosophi the view that the starry sphere moves back and forth for consecutive periods of 900 years. Far from disrupting the link between the two texts, however, Roger's reference to a 900-year period offers excellent grounds to believe that the Lmp was the source from which he drew his information about the sphaera accessionis et recessionis. A period of precisely this length crops up in a paragraph at the very end of the Lmp's section devoted to the Sun (1l. 104-109). Like much of the rest of the text, this paragraph is poorly preserved in the extant manuscripts, and missing altogether from witnesses DX. In its originally state, it may have read as follows:

Dicunt autem quidam doctorum quod sol in DCCCC annis citius movetur per VII gradus et in aliis DCCCC tardius per VII similiter gradus, et nos modo sumus in tardiori, unde dicitur moveri in CCCLXV diebus et VI horis CCCLIX gradus, LIX punctos, LVI minutias, XIX minutias minutiarum. Desunt adhuc de zodiaco III minutie et XLI minutie minutiarum hancque dicunt esse causam mutationis solstitiorum et equinoctiorum.

35 Roger of Hereford, Computus 5.26, ed. Alfred Lohr, Opera de computo saeculi duodecimi, Turnhout: Brepols, 2015, p. 228 (11. 84-89). On the context of this passage, see Nothaft, Walcher of Malvern, pp. 288-290. 
There can be little doubt that the Lmp owed this information, and in particular the bits in italics, to a passage originally found in Walcher of Malvern's aforementioned treatise De Dracone, which was written in 1120 or not long thereafter:

Annus preter quadrantem: CCCLIX gradus, XLV punctos, XI minutias, XV minutias minutiarum. Cum quadrante: CCCLIX gradus, LIX punctos, LVI minutias, XVIII minutias minutiarum et dimidiam, cum quarta parte unius, quod est quadrans. Desunt adhuc cursui solis de zodiaco III minutie et XL [sic] minutie minutiarum. [...] Ad hec ille in DCCCC annis septem gradibus solem retardare in zodiaco dicebat et in aliis DCCCC velocitate eas recuperare et ideo non semper eisdem diebus, sed in diversis solstitia et equinoctia fieri. His autem nostris temporibus illo tardiore cursu solem dicebat uti, unde videtur nobis quia totum sol in anno zodiacum non peragit. ${ }^{36}$

Walcher's De Dracone is one of the earliest texts to document the arrival of mathematical astronomy from Arabic sources in twelfth-century Europe. That said, the information on eclipses contained in De Dracone was very rudimentary and would have quickly come to be regarded as antiquated, which matches the fact that the text enjoyed no wide circulation and appears to have been unknown outside of England. ${ }^{37}$ Its palpable influence on the Lmp therefore provides us with good grounds for assuming that the Lmp was composed in an English setting and at a relatively early date, towards the middle rather than the end of the twelfth century. This is confirmed by the use of our text in Roger of Hereford's Compotus, whose date of composition, 1176, provides us with a dependable terminus ad quem. As for the Lmp's rendition of Walcher's information, it is worth noting that all manuscript witnesses round the $18 \% \frac{3}{4}$ minutiae minutiarum originally mentioned in the source to 19. Another salient change is that from Walcher's division of the zodiac into puncti $\left(=1 / 60^{\text {th }}\right)$, minutiae $\left(1 / 3600^{\text {th }}\right)$, and minutiae minutiarum $\left(1 / 216000^{\text {th }}\right)$ to the more familiar minutes, seconds, and thirds of arc. It is not unlikely that this change was only finalized in the sub-archetype $\gamma$ that came before manuscripts ERSV (see section IV below), where the relevant passage presumably looked as follows:

Unde dicitur moveri in CCCLXV diebus et VI horis CCCLIX gradus, LIX minuta, LVI secunda, XIX tertia. Desunt adhuc de zodiaco tria secunda et XLI tertia.

This line can be reconstructed from the way the passage is represented in manuscripts ERVS, none of which preserves the full wording. EV omit LIX minuta

36 Walcher of Malvern, De Dracone 3.3, ed. Nothaft, Walcher of Malvern, p. 204. The edition emends the numbers at two places. For the quotation above, I have reinstated the numbers found in the manuscripts.

37 Nothaft, Walcher of Malvern, pp. 65-67. 
and reverse the order of units and values. ${ }^{38} R$ contracts CCCLIX gradus, LIX minuta to CCC LIX minuta. ${ }^{39} S$ contains the same contraction, but in addition omits the preceding CCCLXV diebus et VI horis. ${ }^{40}$ The text is in even worse shape in $F$ and $P$, which are independent of the aforementioned sub-archetype $(\gamma)$, but their wording gives us a small hint that the original version of the passage used vocabulary closer to Walcher. Since this vocabulary was outdated by the end of the twelfth century, there would have been a strong incentive for scribes to alter it, leading to a variety of corruptions.

F (108va): Unde dicitur moveri 365 diebus et 6 horis 360 [!] gradus, 59 punctos, 56 minuta et 19 tercia. Deficit adhuc 3 secunda et 413.

$P$ (419v): Unde dicitur moveri in 365 diebus et 7 [!] horis 359 gradus, 59 punctos et 6 minuta, 19 minutias momentorum, 5 secunda [!]. Desunt autem de zodiaco 3 minuta, 40 secunda, vel 61 [!].

Other than specifying the degrees of the zodiac the Sun manages to traverse in 365 $1 / 4$ days, the relevant passage from De Dracone cites the opinion of Walcher of Malvern's teacher Petrus Alfonsi, according to whom there were alternating 900year periods of 'fast' and slow' solar motion and corresponding 'gains' and 'losses' of $7^{\circ}$ on the part of the Sun. The reference frame for these shifts is nowhere specified, but Walcher links them to changes in the dates of the solstices and equinoxes, implying that the changes in solar velocity concern the length of the tropical year. ${ }^{41}$ Readers of the $\operatorname{Lmp}$ would have been tempted to assimilate this statement to the oscillation of $8^{\circ}$ mentioned earlier on in the text, which explains why Roger of Hereford conflated the Lmp's account of the circulus accessionis et recessionis with its later remark about the 900 -year period, despite the fact that the latter was tied to a shift of $7^{\circ}$ rather than $8^{\circ}$. The sub-archetype $(\zeta)$ shared by $F$ and $P$ smoothed out this contradiction and created a stronger sense of coherence between the two passages by changing the number of degrees in the passage drawn from Walcher of Malvern from VII to 8.

Further traces of the Lmp's influence on later texts can be spotted in an obscure work on planetary theory and astronomical computation that starts with the words Investigantibus astronomiam primo sciendum-an incipit very similar to the

$38 E$ (fol. 115v), $V$ (fol. 63rb): 'Unde dicitur moveri in 365 diebus et 6 horis gradus 359, secunda 56, tertia 19. Desunt adhuc de zodiaco 3 secunda et 41 tertia.'

$39 \quad R$ (fol. 3v): 'Unde dicitur moveri in CCCLXV diebus et sex horis gradus CCC LIX minuta, LVI secunda, XIX tertia. Desunt adhuc de zodiaco tria secunda et XLI tertia.'

$40 \quad S$ (fol. 21v): 'Unde dicitur moveri in CCC LIX minuta, LVI secunda, XIX tertia. Desunt adhuc de zodiaco tria secunda et XLI tertia.'

41 See the commentary on this passage in Nothaft, Walcher of Malvern, pp. 284-290. 
Lmp's Investigantibus astronomie rationes primo ponendum. ${ }^{42}$ As a matter of fact, the first paragraphs of this anonymous Theorica look very much like an attempt to reproduce the opening of the $L m p$ with different wording. ${ }^{43}$ Another suggestive example is a remark on the motion of the apsidal lines of all planets, which appears to have inspired a similar passage in the much more popular Theorica planetarum of pseudo-Gerard of Cremona:

Quidam enim asserebant apsides omnium planetarum praeter lunam esse immobiles; alii vero quamlibet earum moveri in 900 'tis annis <per> 7 gradus ante, id est contra firmamentum, et in aliis 900 tantundem retro. ${ }^{44}$

Since Walcher of Malvern's De Dracone never mentions the apsidal lines or apogees of the planets, this text is unlikely to be immediate source behind the statement found in Investigantibus. To be sure, the Lmp does not specifically link the 900-year period to apsidal precession either, but it does state in no unclear terms that the apogees of all planets other than the Moon partake in the motion of the eighth sphere (11. 154-155). An even clearer trace of the Lmp's influence can be discerned in the way Investigantibus repeats the same mistakes in defining the Moon's diameter-increment and equation of centre that we have noted above as being characteristic of the Lmp and its source Ptolomeus. Investigantibus attributes these definitions to al-Farghānī and his followers, which is striking given that alFarghāni is the only author mentioned in the $\operatorname{Lmp}$ (1.233). The specific wording used in Investigantibus, too, goes to suggest that $\mathrm{Lmp}$, rather than Ptolomeus, was its immediate source for the definitions in question. In the case of the equation of centre, for which both texts provide an incorrect definition, the verbal parallels are as follows:

\begin{tabular}{|c|c|}
\hline $\operatorname{Lmp}(11.178-180)$ & Investigantibus: ${ }^{45}$ \\
\hline $\begin{array}{l}\text { Equatio puncti est distantia capitum } \\
\text { duarum linearum in superiori } \\
\text { circumferentia epicicli, quarum una a } \\
\text { centro terre et alia a centro excentrici } \\
\text { circuli exeunt per centrum epicicli. }\end{array}$ & $\begin{array}{l}\text { Aequatio centri secundum eos dicitur } \\
\text { distantia in circulo signorum capitum } \\
\text { duarum linearum, quarum una ducitur a } \\
\text { centro terrae per centrum lunae ad } \\
\text { circulum signorum, et alia a centro }\end{array}$ \\
\hline
\end{tabular}

This is the text edited by Pedersen, 'A Twelfth-Century Planetary Theorica', pp. 224-302.

43 Pedersen, 'A Twelfth-Century Planetary Theorica', p. 224 (Jn1-3).

44 Pedersen, 'A Twelfth-Century Planetary Theorica', p. 266 (Jn 218). For the corresponding passage in the standard Theorica planetarum, see Ibid., p. 316: 'Nota quod auges dicuntur moveri versus orientem 7 gradus in 900 annis et totidem versus occidentem in aliis 900 annis'. See also the edition of this text by Carmody, Theorica Planetarum Gerardi, p. 46.

45 Pedersen, 'A Twelfth-Century Planetary Theorica', p. 239 (Jn 84). I omit Pedersen's conjectural emendation in this passage, which was meant to salvage the definition. 


\begin{tabular}{|l|l|}
\hline & $\begin{array}{l}\text { excentrici per centrum lunae ad eundem } \\
\text { circulum. }\end{array}$ \\
\hline
\end{tabular}

Meanwhile, what would have been the correct definition for the equation of centre is delivered under the guise of the diameter-increment:

\begin{tabular}{|l|l|}
\hline $\begin{array}{l}\text { Lmp (ll. 184-187): } \\
\text { Equatio diversitatis diametri circuli brevis } \\
\text { est distantia capitum duarum linearum in } \\
\text { superiori circumferentia epicicli, quarum } \\
\text { una exit a centro terre et alia a centro } \\
\text { predicto, quod est inter terram et } \\
\text { longitudinem propiorem excentrici, per } \\
\text { centrum epicicli. }\end{array}$ & $\begin{array}{l}\text { Investigantibus }{ }^{46} \\
\text { esdem dicitur distantia in circulo } \\
\text { signorum capitum duarum linearum, quae } \\
\text { circulum signorum: una quidam a centro } \\
\text { terrae, et altera a puncto distante a centro } \\
\text { terrae quantum et centrum excentrici ex } \\
\text { opposito secundum eandem lineam. }\end{array}$ \\
$\begin{array}{l}\text { Lmp (ll. 176-178): } \\
\text { Hoc autem centrum semper est in } \\
\text { opposita parte centri excentrici circuli } \\
\text { lune et tantum distat a centro terre } \\
\text { quantum centrum excentrici. }\end{array}$ & \\
\hline
\end{tabular}

All of the evidence gathered so far allows us to conclude that the Lmp was most likely composed in the third quarter of the twelfth century, prior to Roger of Hereford's Compotus of 1176 and some time after the text Ptolemaeus associated with Abraham Ibn Ezra and the Tables of Pisa, which dates itself to AD 1145. There are also strong reasons for believing that the text originated in England. For one thing, the author of the Lmp appears to have come across a passage in Walcher of Malvern's De Dracone, which is not known to have exerted any influence outside England. Next to Roger of Hereford, who was obviously based in the West Midlands, the Lmp was also clearly known to whoever put together the treatise Investigantibus, which was written in the last quarter of the twelfth century and shows several points of contact with the London Tables adapted from the Tables of Pisa ${ }^{47} \mathrm{~A}$ final point worth making is that no fewer than four of the nine surviving manuscripts of the Lmp show signs of having been copied in England. Among these are the two earliest witnesses, $R$ (s. XIII ${ }^{1 / 2}$ ) and $S\left(\mathrm{~s}\right.$. XIII' $\left.{ }^{2 / 2}\right)$, as well as $E\left(\mathrm{~s} . \mathrm{XIV}^{1 / 4}\right)$ and the chronological outlier $D$ (fol. $\mathrm{XV}^{\mathrm{med}}$ ).

\footnotetext{
Ibid., p. 239 (Jn 85).

Ibid., pp. 211-214.
} 


\section{Other sources}

\section{(a) al-Farghān̄̄}

As mentioned earlier, the Lmp includes an explicit reference to the ninth-century astronomer al-Farghānī (Alfraganus), whom it credits with using the expression circulus equans motum to refer to a circle of the same radius as the eccentric deferent whose centre is the equant point of a given planet (11. 231-234). This brief acknowledgment is probably enough to establish which (if any) of the extant two twelfth-century Latin translations of al-Farghānī's Jawāmi' 'ilm al-nujūm (Elements of Astronomy) the author of the Lmp employed as a source. In the translation attributed to Gerard of Cremona, which must have been made at some unknown point in time between Gerard's arrival in Toledo (presumably during the 1140s) and his death in 1187, the equant circle is introduced as orbis excentricus aequans cursus. ${ }^{48}$ By contrast, the earlier translation by John of Seville, datable to AD 1135, renders the same phrase as circulus egresse cuspidis equans motum.$^{49}$ It would appear that the author of the Lmp took the Latin phrase from John of Seville, but replaced the cumbersome expression egresse cuspidis with the adjective excentricus (as seen in $11.324,337-338$ and 344). ${ }^{50}$ This hypothesis can be tested by examining passages in al-Farghānī that are clearly echoed in the Lmp. Two such passages can be found in ch. 13, which provided material for the Lmp's account of the five motions that govern the position of the Moon (11. 114-148) as well as for its later comments on the corresponding rates of motion (1l. 370-382). ${ }^{51}$ Witness, for instance, the following three sentences in the $\mathrm{Lmp}$, as compared to the parallel passages in the two translations:

48 See ch. 12 in the edition by Romeo Campani, Alfragano (al-Fargānī): Il 'Libro dell'aggregazione delle stelle', Città di Castello: Lapi, 1910, p. 114.

49 See ch. 12 in the edition by Francis J. Carmody, Al Farghani Differentie Scientie Astrorum, Berkeley, CA, 1943, pp. 23-24. For the date of this translation, see Manuel Alonso Alonso, 'Juan Sevillano, sus obras proprias y sus traducciones', Al-Andalus 18 (1953), pp. 17-49, at pp. 38-39; Lynn Thorndike, 'John of Seville', Speculum 34 (1959), pp. 20-30, at pp. 27-28; Charles Burnett, 'John of Seville and John of Spain: A Mise au point', Bulletin de philosophie médiévale 44 (2002), pp. 59-78, at p. 61.

50 This use of excentricus (or ecentricus) may have been inspired by the treatise Ptolomeus. See MS Cambridge, Fitzwilliam Museum, McClean 165, fol. 73r-v: 'Circulus quidem predictus dicitur "excentricus" quoniam centrum ipsius est extra firmamenti centrum et terre.' On twelfthcentury astronomical vocabulary, see Emmanuel Poulle, 'Le vocabulaire de l'astronomie planétaire du XII au XIV siècle', in La diffusione delle scienze islamiche nel medio evo europeo, Rome: Accademia nazionale dei Lincei, 1987, pp. 193-212.

51 See ch. 13 in Carmody, Al Farghani, pp. 24-25, and Campani, Alfragano, pp. 117-118. One should also mention al-Farghānì's account of the motions of Mercury in ch. 14, which provided the basis for $\operatorname{Lmp}$, 11. 342-347. 


Lmp (1l. 370-376):
Luna vero quinque motus habet: unum quo
corpus lune in epiciclo movetur ab oriente
in occidentem omni die XIII gradibus et IIII
minutis de gradibus circuli brevis. Alium
quo centrum epicicli simul cum epiciclo
rotatur ab occidente versus orientem
XXIIII gradibus et XXIII minutis de circulo
excentrico deferente centrum. Tertium
autem quo centrum excentrici deferentis
centrum epicicli movetur ab oriente in
occidentem XI gradibus et IX minutis
vertens secum longitudinem longiorem
excentrici, id est augem lune.

Lmp (11. 370-376):

Luna vero quinque motus habet: unum quo corpus lune in epiciclo movetur ab oriente in occidentem omni die XIII gradibus et IIII minutis de gradibus circuli brevis. Alium quo centrum epicicli simul cum epiciclo rotatur $a b$ occidente versus orientem XXIIII gradibus et XXIII minutis de circulo excentrico deferente centrum. Tertium autem quo centrum excentrici deferentis centrum epicicli movetur ab oriente in occidentem XI gradibus et IX minutis vertens secum longitudinem longiorem excentrici, id est augem lune.

\author{
Elements, ch. 13 (tr. Gerard of \\ Cremona): ${ }^{52}$
}

Corpus quidem lunae movetur in orbe revolutionis ad occidentem 13 gradibus et 4 minutis de partibus circuli orbis revolutionis; et movetur centrum orbis revolutionis in orbe excentrico ad partem orientis secundum quantitatem partium illius orbis cuius centrum est centrum orbis signorum: 24 gradibus et 23 minutis; et currit centrum orbis excentrici in circulo parvo cuius centrum est centrum orbis signorum et revolvitur longitudine longiore in rotunditatem ad occidentem 11 gradibus et 9 minutis.

Elements, ch. 13 (tr. John of Seville): ${ }^{53}$

Corpus scilicet lune movetur in circulo brevi versus occidentem $13^{\circ}$ et $4^{\prime}$ de gradibus circuli brevis; et movetur cuspis circuli brevis in circulo egresse cuspidis versus orientem secundum quantitatem gradus circuli cuius cuspis est cuspis circuli signorum $24^{\circ}$ et $23^{\prime}$; et movetur cuspis circuli egresse cuspidis in circulo parvo cuius cuspis est cuspis circuli signorum et vertit longitudinem longiorem in rotunditatem versus occidentem $11^{\circ}$ et $9^{\prime}$.

The similarities in the second of these pairings become more telling if one takes into account that the $\mathrm{Lmp}$ replaces some of the technical vocabulary found in John of Seville's translation, using excentricus instead of egresse cuspidis and epiciclus rather than circulus brevis. It is clear, however, that the latter term was familiar to the author of the Lmp. It first appears in 1.115 as a definition of epiciclus and then again multiple times as part of the expression equatio diversitatis diametri circuli brevis. What is particularly striking is the occurrence of the same term in 1l. 371372 , where the Lmp assigns to the epicycle a westward motion of $13 ; 4^{\circ}$ per day. The first time circulus brevis appears in the corresponding passage of John of Seville's Elements, the Lmp replaces it with epiciclus (1.370), but it refrains from swapping

52 Campani, Alfragano, pp. 117-118.

53 Carmody, Al Farghani, p. 25. 
terms a second time when it goes on to specify that these $13 ; 4^{\circ}$ are measured on the circumference of the epicycle. Here, the text simply repeats the phrase de gradibus circuli brevis already employed by John of Seville, whereas Gerard of Cremona has de partibus circuli orbis revolutionis. In common with John's translation, the Lmp uses the pairing augis and oppositum (or oppositio) augis to refer to the apogee and perigee of a given epicycle or deferent..$^{54}$ Gerard of Cremona's translation uses the same Arabic loan word, but distinguishes between aux as a nominative and augis as a genitive form. ${ }^{55}$ This subtle difference probably clinches the case in favour of John of Seville, especially considering that there are no comparable instances of close correspondence between the Lmp and Gerard of Cremona's version, where the epicycle is called orbis revolutionis and eccentrics appear as orbes egredientium centrorum as well as orbes excentricorum. ${ }^{56}$

(b) The Toledan Tables and Scito quod annus lunaris

While most of its technical vocabulary is Latin and depends on earlier Latin texts, the Lmp also prominently features five words drawn from the Arabic language. In their order of appearance, these are: zimzalraz (1.24), almucantarath (1.24), azimuz (1. 26), halissa (ll. 60, 81-82), and geuzahar (1l. 396, 404-406, 410). Three of these words are conventional in the sense that they can be found in numerous other Arabic-influenced Latin astronomical texts of the twelfth and thirteenth centuries. ${ }^{57}$ The other two, however, are rare and warrant further comment. One of these, zimzalraz, must have been an attempt to transliterate the Arabic samt al$r a$ 's (the 'direction of the head'), which is the ancestor of 'zenith'. ${ }^{58}$ If Latin $z$ is accepted as the equivalent of Arabic sin, then two scenarios suggest themselves: either samt al-ra's was first rendered as zimtalraz, which is indeed the reading found in manuscripts $S V$ (zimtaleaz in X), or the original transliteration was zimet alraz, after which the common Latin abbreviation for '-et' was confused with another $z$.

Unlike zimzalraz, which to my knowledge is not attested outside the $\operatorname{Lmp}$, there are some known precedents for halissa, which is the term the Lmp introduces in 1. 60 to denote the arc between the apogee and the mean position of the Sun, i.e. its arc of anomaly. This is recognizably the Arabic al-hișsa, which literally means 'portion', 'lot', or 'share'. The Lmp translates the term in accordance with its colloquial meaning, as portio (11. 80-82), and continues to use this Latin expression

\footnotetext{
Ibid., p. 23.

Campani, Alfragano, p. 110 and passim.

Ibid., pp. 111, 113-114, and passim.

57 For almucantharat and azimuth, see Paul Kunitzsch, Glossar der arabischen Fachausdrücke in der mittelalterlichen europäischen Astrolabliteratur, Göttingen: Vandenhoeck \& Ruprecht, 1982, pp. 536538, 550-553. For geuzahar, see Poulle, 'Le vocabulaire', pp. 199-220.

58 Kunitzsch, Glossar der arabischen Fachausdrücke, pp. 546-549.
} 
to refer to the anomalies of the Moon and the other planets. Several of the manuscripts of the Lmp render the corresponding Arabic term not as halissa, but as halipsa or alipsa, a variant otherwise documented in the thirteenth-century MS Madrid, Biblioteca nacional de España, 10016, fol. 69ra. There the Sun's alipsa is mentioned in the context of some rules for eclipses that follow right after the only known copy of Robert of Chester's revised version of the zijj of al-Khwārizmī translated by Adelard of Bath. ${ }^{59}$ Both Halissa and alipsa derived from al-hisșa via metathesis of $h$ and al, which is reminiscent of the way the title of an arithmetical work of the mid-twelfth century, written by one H. Ocreatus, a pupil of Adelard of Bath, rendered al-hisāb ('reckoning') as helcep. ${ }^{60}$

An occurrence of al-hisssa that did not succumb to metathesis can instead be witnessed in a set of Latin canons for the so-called Toledan Tables, which begin with the words Scito quod annus lunaris. ${ }^{61}$ These canons, which in manuscript headings are often attributed to Azarquiel (al-Zarqālī or al-Zarqālluh, d. 1100), appear to have been rather popular during the second half of the twelfth and for much of the thirteenth century. This holds true in particular for England, where most of the extant copies originated.$^{62}$ In common with the Lmp, this text translates alhissa as portio and uses it exclusively in its section devoted to the calculation of the solar equation..$^{63}$ It retains the Latin portio and aequatio portionis when discussing the five planets, but switches to pars lunae and aequatio partis when doing the same

59 Millás Vallicrosa, Las traducciones, p. 251. A variant of alipsa is halipsa, which appears in copies ERSV of the Lmp and in a unique text on how to calculate planetary longitudes (Doctrina equacionis omnium planetarum) that follows on the Lmp in S (fol. 31r). For other transliterations, see Heinrich Suter, Die astronomischen Tafeln des Muhammed ibn Mūsā al-Khwārizmī in der Bearbeitung des Maslama ibn Ahmed al-Madjrīți und der latein. Übersetzung des Athelhard von Bath, Copenhagen: Høst \& Søn, 1914, p. 46, and entry no. 10 in the table of loan words included in Mercier, 'Astronomical Tables', p. 116.

60 See Charles Burnett, 'Algorismi vel helcep decentior est diligentia: The Arithmetic of Adelard of Bath and His Circle', in Menso Folkerts (ed.), Mathematische Probleme im Mittelalter: Der lateinische und arabische Sprachbereich, Wiesbaden: Harrassowitz, 1996, pp. 221-331, at pp. 235-236. I am very grateful to Prof. Burnett for discussing the Arabic vocabulary in the Lmp with me.

${ }_{61}$ These are canons $\mathrm{Ca}$ edited in Fritz S. Pedersen, The Toledan Tables, 4 vols, Copenhagen: Reitzel, 2002, pp. 215-311.

62 As noted by Pedersen, The Toledan Tables, p. 196. Early copies from England include MSS Cambridge, University Library, Kk.1.1, fols 125r-137r (s. XIII ${ }^{\mathrm{med}}$ ), Oxford, Merton College, 259, fols 53r-55v (s. XIII ${ }^{1 / 2}$ ), Oxford, Bodleian Library, Savile 22, fols 1r-12r (s. XIII ${ }^{\text {med }}$ ), Oxford, Bodleian Library, Savile 21, fols 27ra-40va (s. XIII).

63 See Ca 92, ed. Pedersen, The Toledan Tables, p. 256 ('et quod remanserit voca alhissa, id est portio'). A version of the same passage appears in the obscure Liber coaequationis planetarum translatus a magistro G. Cremonense de Arabico in Latinum, found uniquely in MS Oxford, Bodleian Library, Digby 47, fols $61 \mathrm{r}-67 \mathrm{v}$ (s. XIII/XIV), at fol. 62v: 'Cum volueris coequare solem extrahe medium cursum eius sicut predictum est et scribe eum in duobus locis et minue ex uno augem solis, id est duo signa, et XVII gradus et 50 minuta [...] et quot remanserit nota alchissa, id est portio vel pars.' See Pedersen, The Toledan Tables, pp. 727-728, 734-736. 
for the Moon. On the whole, however, scito quod annus lunaris maintains a vocabulary strikingly similar to the $\mathrm{Lmp}$, with expressions such as aequatio puncti and aequatio diversitatis diametri circuli brevis being used in much the same way. ${ }^{64}$ The link between the Lmp and the Toledan Tables is strengthened by the small handful of numerical values mentioned in our text. Most significant in this respect is the longitude of the solar apogee at $2 \mathrm{~s} 17 ; 50^{\circ}$ (in ll. 61-62 and 83-84), which is a characteristic hallmark of these tables.$^{65}$ In light of its presence in the Lmp, it seems a safe bet that another solar parameter, the maximum equation of $1 ; 59,10^{\circ}$ (1l. 5758), was likewise lifted from the Toledan Tables. ${ }^{66}$

Yet more evidence for the influence of these tables and of Scito quod annus lunaris on the Lmp can be derived from its closing paragraphs dealing with the locations of the planetary apogees and ascending nodes. The $\operatorname{Lmp}$ here begins by informing us about the signs in which the apogee for each of the seven planets is located, but refrains from offering more precise quantitative information (ll. 396399). All manuscripts agree that the Sun and Venus have their apogees in Gemini, Saturn in Sagittarius, Jupiter in Virgo, Mars in Leo, and Mercury in Libra. This conforms neatly to the Toledan Tables, whose standard set of apogeal longitudes is as follows: ${ }^{67}$

\begin{tabular}{|c|c|c|c|}
\hline & signs & degrees & minutes \\
\hline Sun & 2 & 17 & 50 \\
\hline Saturn & 8 & 0 & 5 \\
\hline Jupiter & 5 & 14 & 30 \\
\hline Mars & 4 & 1 & 50 \\
\hline Venus & 2 & 17 & 50 \\
\hline Mercury & 6 & 17 & 30 \\
\hline
\end{tabular}

64 See in particular canons Ca 92-105, ed. Pedersen, The Toledan Tables, pp. 256-262. Table headings in manuscripts of the Toledan Tables that reflect the vocabulary in Scito quod annus lunaris are documented Ibid., pp. 1250-1251, 1265, 1274, 1282, 1290, 1298. Note that many of the copies with these headings tend to be early (s. XIII) and from England.

65 Pedersen, The Toledan Tables, p. 256 ( Ca 92). The Toledan Tables and Scito quod annus lunaris were probably translated too early to be of any help in dating the Lmp. A Latin version certainly existed by 1141 , the year when Raymond of Marseille adapted them to the meridian of Marseille. See Raymond of Marseilles, Opera omnia, vol. I, Traité de l'astrolabe, Liber cursuum planetarum, ed. MarieThérèse d'Alverny, Charles Burnett and Emmanuel Poulle, Paris: CNRS, 2009, pp. 126-341. The tables are also mentioned in connection with the year 1138 in a commentary on the pseudoPtolemaic Iudicia found in MS London, British Library, Cotton App. VI, fol. 21va. According to Hasse, 'Stylistic Evidence', pp. 30-31, the translator behind Scito quod annus lunaris was probably John of Seville, who was active in the 1120s and 1130s.

66 See the table of maximum solar equations in José Chabás and Bernard R. Goldstein, A Survey of European Astronomical Tables in the Late Middle Ages, Leiden: Brill, 2012, p. 66.

67 Pedersen, The Toledan Tables, pp. 1222-1226. 
These values differ conspicuously from the apogeal longitudes listed in a table that accompanies the Lmp in the closely related manuscripts $E V$.

\begin{tabular}{|c|c|c|c|}
\hline Auges & signa & gradus & minuta \\
\hline Solis & 2 & 17 & 50 \\
\hline Saturni & 8 & 10 & 42 \\
\hline Iovis & 5 & 22 & 57 \\
\hline Martis & 4 & 11 & 48 \\
\hline Veneris & 2 & 17 & 45 \\
\hline Mercurii & 6 & 25 & 40 \\
\hline
\end{tabular}

Values very close, but not quite identical to those in $E V$ are transmitted in a table of apogees with the heading Altus locus planetarum super Pisam, which appears to belong to a late-twelfth century copy of Abraham Ibn Ezra's Pisan Tables. ${ }^{68}$

\begin{tabular}{|c|c|c|c|}
\hline Auges & signa & gradus & minuta \\
\hline Solis & 2 & 27 & 36 \\
\hline Saturni & 8 & 10 & 37 \\
\hline Iovis & 5 & 22 & 54 \\
\hline Martis & 4 & 11 & 44 \\
\hline Veneris & 2 & 27 & 36 \\
\hline Mercurii & 6 & 25 & 36 \\
\hline
\end{tabular}

Unlike the table of apogees, which was probably only introduced in the subarchetype shared by $E V$, a table listing the longitudes of the ascending nodes (or geuzahar) of the five planets also shows up in manuscripts $F$ and $S$ and hence may have already existed in the archetype that ties together manuscripts DFPX and ERSV. Another good reason for thinking so is the final sentence of the Lmp (1l. 418421), which speaks of a table that makes it possible to determine whether a planet is ascending towards or descending from the ecliptic and whether this happens at a northern or southern latitude. In the manuscripts that contain this bit of the text (EFRSV), it is claimed that the information needed to make this determination is the planet's latitude ('Cognita enim eius latitude per tabulam facile cognosci potest' etc.), but this fails to make good sense. Much rather, one would expect the text to mention the ecliptical longitude, since combined knowledge of the longitude of the planet itself and the longitude of its ascending node will indeed be enough to infer that it is currently (a) 'ascending toward the north', (b)

68 MS Paris, Bibliothèque nationale de France, lat. 16208, fol. 3v. The Tables of Pisa, written by the same hand, appear on fol. $4 \mathrm{r}-\mathrm{v}$. For a description of this manuscript, see David Juste, Catalogus codicum astrologorum latinorum, vol. II, Les manuscrits astrologiques latins conservés à la bibliothèque nationale de France à Paris, Paris: CNRS, 2015, pp. 236-240. For tables with similar values in other manuscripts, see Pedersen, The Toledan Tables, pp. 1226-1227. 
'descending from the north', (c) 'ascending toward the south', or (d) 'descending from the south', as mentioned in 1l. 414-417. Without the table in EFSV, however, the text would provide no more than the signs in which the ascendings nodes of the five planets are located (1l. 405-407). With regard to the sign-placements mentioned in the text itself, it is worth noting that the manuscripts are far from unanimous as to which planet's node is found in which sign of the zodiac.

\begin{tabular}{|c|c|c|c|c|}
\hline Planet & $D X$ & $R$ & FP & $E S V$ \\
\hline Saturn & Cancer & Cancer & Leo & Cancer \\
\hline Jupiter & Cancer & Leo & Cancer & Leo \\
\hline Mars & Taurus & Taurus & Taurus & Taurus \\
\hline Venus & Pisces & Pisces & Pisces & Capricorn \\
\hline Mercury & Capricorn & Capricorn & Capricorn & Sagittarius \\
\hline
\end{tabular}

The sign-placements in DX happen to correspond perfectly to the list of longitudes for the ascending nodes commonly found alongside the Toledan Tables as well as in two copies of Scito quod annus lunaris: ${ }^{69}$

\begin{tabular}{|c|c|c|c|}
\hline Geuzahar & signa & gradus & minuta \\
\hline Saturni & 3 & 10 & 30 \\
\hline Iovis & 3 & 0 & 1 \\
\hline Martis & 1 & 1 & 51 \\
\hline Veneris & 11 & 17 & 50 \\
\hline Mercurii & 9 & 17 & 3 \\
\hline
\end{tabular}

The only difference between these values and the sign-placements in $R$ concerns the ascending node of Jupiter, which according to $R$ and ESV appears in Leo rather than Cancer. A known twelfth-century source that would support this placement are the astronomical tables for the meridian of Hereford that the aforementioned Roger of Hereford produced in 1178. Roger locates Jupiter's node at $4 \mathrm{~s} 0 ; 1^{\circ}$ rather than $3 \mathrm{~s} 0 ; 1^{\circ 70}$ It is interesting to note that Roger deviates from the vulgate tradition a second time when he moves Mercury's node from Capricorn to Sagittarius, giving its longitude as $8 \mathrm{~s} 17 ; 3^{\circ} .{ }^{71}$ Together with the variant placement of Jupiter, this

69 See Pedersen, The Toledan Tables, pp. 313-314, 1230-1233. The rationale behind these values is explained in G. J. Toomer, 'A Survey of the Toledan Tables', Osiris 15 (1968), pp. 5-174, at pp. 4546.

70 MS Madrid, Biblioteca nacional de España, 10016, fol. 78(bis)v. See Mercier, 'Astronomical Tables', p. 108; Pedersen, The Toledan Tables, p. 1231.

71 MS Madrid, Biblioteca nacional de España, 10016, fol. 82r. See also the list of Genzahar planetarum secundum Rogerum infantem in MS Brussels, Bibliothèque Royale, 1022-47, fol. 13r, which features the same values as the Madrid codex. 
corresponds exactly to the numbers shown in the table contained in $F$, which are as follows:

\begin{tabular}{|c|c|c|c|}
\hline & signa & gradus & minuta \\
\hline Saturni & 3 & 10 & 30 \\
\hline Iovis & 4 & 0 & 1 \\
\hline Martis & 1 & 1 & 51 \\
\hline Veneris & 11 & 17 & 50 \\
\hline Mercurii & 8 & 17 & 3 \\
\hline
\end{tabular}

Given Roger of Hereford's use of the Lmp in his Compotus of 1176 (see section II above), it may be tempting to suppose that his variant numbers for Jupiter and Mercury were due to the same source. One must note, however, that the text in $F$ (together with that in $P$ ) continues to place Mercury in Capricorn, but deviates from $R$ by flipping the signs of Jupiter and Saturn, putting the latter in Leo and the former in Cancer. The position of Mercury only changes in ESV, where the text puts the node in Sagittarius, while the accompanying table repeats Roger's and F's longitude of $8 \mathrm{~s} 17 ; 3^{\circ}$. In addition, all three manuscripts move the node of Venus from Pisces to Capricorn, which agrees with the information found in their respective table: $9 \mathrm{~s} 17 ; 50^{\circ}$ instead of $11 \mathrm{~s} 17 ; 50^{\circ}$. It would appear that the variants in the text of ESV were triggered by scribal errors that had already crept into the table at an earlier stage. The 'incorrect' placement of Mercury's node, which has a parallel in Roger of Hereford's astronomical tables, may be due to a change from VIIII to VIII, while the shift of Venus from Pisces to Capricorn is best explained as a flip between XI and IX. The scribe of the sub-archetype shared by ESV was keen to make the signs mentioned in the text conform to those in the table and hence put the nodes of Venus and Mercury in Capricorn and Sagittarius.

There remains the strange fact that all preserved versions of the geuzahar-table in the Lmp place Jupiter's node in Leo, as does the text in ERSV, whereas the late copies in DX follow the Toledan Tables in making Cancer the shared sign for the ascending nodes of Saturn and Jupiter. Since DX omit the table together with the corresponding final paragraph of the text (1l. 410-421), the question of priority seems to be beyond full resolution. For the edition below, I have with some hesitation accepted the reading Iovis geuzahar in Leone attested in the majority of the manuscripts, treating it as a case of lectio difficilior potior.

\section{Transmission}

The Lmp survives in eight more or less complete copies as well as a heavily abridged version, which I shall briefly describe in what follows: 
B = Bernkastel-Kues, Cusanusstiftsbibliothek (St.-Nikolaus-Hospital), 212, fol. 130r$\mathrm{V}^{72}$

This is an abridged copy from the beginning of the fifteenth century, which only features material taken from 11.1 to 200. The first 29 lines of the Lmp appear in full, after which $B$ begins to shorten the text and leave out substantial parts, including the entire description of the diagram for the Sun (as well as the diagram itself). The exemplar used for this abridged version must have been a descendant of $\varepsilon$, the sub-archetype shared by $E V$. Where variants can be compared, they suggest that $V$ is B's closest surviving relative. In 1l. 61-62, B replaces the position of the solar apogee in the original text with $3 \mathrm{~s} 0 ; 6^{\circ}$. This replacement was presumably made on the basis of the Alfonsine Tables, which would have predicted this value for June $1388 .^{73}$ It is conceivable that this was the date of B's exemplar. Hindu-Arabic numerals are employed throughout.

$\mathrm{D}=$ Oxford, Bodleian Library, Digby 97 , fols $138 \mathrm{r}-142 \mathrm{r} .{ }^{74}$

This copy is part of a two-part fascicle of $4+16$ quires (parchment) that starts on fol. 137r and ends with fol. 292, which is also the final leaf of the codex. Our text shares a quire with a treatise on the motion of the eighth sphere citing an observation for $1395,{ }^{75}$ which must be a year in the past. D's rendition of the Lmp features several revisions and improvements, both to the wording and to the technical content of the original text. Some idea as to the date of this revision may be gleaned from the value for the solar apogee in 11.61-62, which is here changed to $3 \mathrm{~s} 0 ; 40,34^{\circ}$. Based on the Alfonsine Tables, this would be the position of the apogee close to 1 December AD $1446 .^{76}$ Diagrams corresponding to Figs. 1-4 appear on fols 139r, 140r, 141r-v. In place of the final paragraph starting Sunt ergo geuzahar etc. (1l. 366-376), this recension adds a brief text on the divisions of time, which employs a partition of the hour into 40 'moments' familiar from computistical

72 See the description by David Juste, 'MS Bernkastel-Kues, Cusanusstiftsbibiothek, 212' (update: 17.11.2017), Ptolemaeus Arabus et Latinus. Manuscripts, URL = <http://ptolemaeus.badw.de/ms/18>. This copy was first mentioned by Benjamin and Toomer, Campanus of Novara, pp. 88-89, who wrongly extended its range to 'fols 130r-36v'.

73 The approximate time was determined using the program Deviations, available at $<$ http://www.raymondm.co.uk>.

74 William D. Macray, Catalogi Codicum Manuscriptorum Bibliothecae Bodleianae, vol. IX, Oxford: Clarendon Press, 1883, cols 105-108; R. W. Hunt and A. G. Watson, Bodleian Library Quarto Catalogues, vol. IX.2, Notes on Macray's Descriptions of the Manuscripts, Oxford: Bodleian Library, 1999, pp. 52-53.

75 See on this text Lynn Thorndike, 'Thomas Werkwoth On the Motion of the Eighth Sphere', Isis 39 (1948), pp. 212-215; John North, Richard of Wallingford, 3 vols, Oxford: Clarendon Press, vol. III, pp. 241-246; C. Philipp E. Nothaft, 'Criticism of Trepidation Models and Advocacy of Uniform Precession in Medieval Latin Astronomy', Archives for History of Exact Sciences 71 (2017), pp. 211241, at pp. 230-231.

76 As in n. 73. 
works. ${ }^{77}$ Below this final paragraph is an attribution of the foregoing work to Robert Grosseteste (fol. 142r: Explicit Lincolniensis in Theorica spere). The copy employs Hindu-Arabic numerals throughout.

$\mathrm{E}=$ Erfurt, Universitäts- und Forschungsbibliothek, CA 4 ${ }^{\circ} 357$, fols $114 \mathrm{v}-118 \mathrm{v} .^{78}$

This copy is part of a composite codex in $4^{\circ}$ of 133 fols. It belongs to a fascicle (fols 101-124) written by two different English hands of the early fourteenth century (s. $\mathrm{XIV}^{1 / 4}$ ). The heading on fol. $114 \mathrm{v}$ reads Incipit liber de motibus planetarum (as in S). The text has no colophon, but segues into a sequence of chapters from Adelard of Bath's translation of the zij of al-Khwārizmì together with a shadow table (fols $118 \mathrm{v}-119 \mathrm{r}) \cdot{ }^{79}$ This material can also be found in S. Diagrams corresponding to Figs. 1-4 appear on fols $115 \mathrm{r}, 116 \mathrm{v}, 117 \mathrm{v}, 118 \mathrm{r}$. A fifth diagram, not mentioned in the text, appears on fol. 118v. Tables for apogees (auges) and ascending nodes (geuzahar) appear on fol. 118r. Hindu-Arabic numerals are used throughout.

$\mathrm{F}=$ Paris, Bibliothèque nationale de France, lat. 7298, fols 107va-111vb. ${ }^{80}$

This copy was made in Northern France in the first half of the fourteenth century. It is part of a codex measuring $370 \times 250 \mathrm{~mm}$ and comprising $174 \mathrm{fols}$ in double columns, all written in a single hand. Its rendition of the $\mathrm{Lmp}$ is severely affected by scribal errors, corruptions, and smaller omissions, mostly due to homeoarchy. Diagrams corresponding to Figs. 1-4 appear on fols 108v, 109v, 110v, 111v. A brief colophon on fol. $111 \mathrm{vb}$ reads Explicit theorica planetarum. Hindu-Arabic numerals are used throughout. The manuscript is available online at <http://gallica.bnf.fr/ark:/12148/btv1b10721165n.r=latin\%207298?rk=21459;2>.

$77 D$ (fol. 142r): ‘Tempus dividitur in partes maiores et minores. Maiores scilicet sunt perigeneses quod est spacium quindecim mille annorum et tunc revertuntur omnes stelle in sue creacionis statum. Evum est spacium mille annorum. Seculum est spacium 100 annorum. Indictio est spacium quindecim annorum, continens tria lustra. Lustrum est spacium quinque annorum. Partes minores sunt dies. Dividitur tamen dies in naturalem et artificalem. Dies naturalis habet diem et noctem. Dies artificiales est spacium ab ortu solis usque ad occasum. Hora est 24 pars diei naturalis. Triens est tercia pars alicuius rei integre. Triens est tercia pars alicuius rei integre. Triens hore est tercia pars hore. Triens diei est tercia pars diei. Quadrans est quarta pars diei vel alterius rei. Momentum est quadragesima pars unius hore. Bisse momentum est dimidium momentum.'

78 Wilhelm Schum, Beschreibendes Verzeichnis der amplonianischen Handschriften-Sammlung zu Erfurt (Berlin: Weidmann, 1887), pp. 597-600. For an updated description, see <http://manuscriptamediaevalia.des.

79 Ezic Elkaurezmi, c. 27-28b, ed. Suter, Die astronomischen Tafeln, pp. 20-22. The wording of the canons comes closest to that in the lost MS C (Chartres, Bibliothèque municipale, 214). The shadow table corresponds to the one edited and discussed in Pedersen, The Toledan Tables, pp. 991-993.

80 David Juste, 'MS Paris, Bibliothèque nationale de France, lat. 7298' (update: 21.02.2018), Ptolemaeus Arabus et Latinus. Manuscripts, URL = <http://ptolemaeus.badw.de/ms/175>. 
$\mathrm{P}=$ Parma, Biblioteca Palatina, $718-720$, fols $418 \mathrm{v}-422 \mathrm{r}^{81}$

This copy is part of a codex in $8^{\circ}$ of 478 fols divided into three separate volumes (s. $\mathrm{XIII}^{\mathrm{ex}}$ or XIV ${ }^{\mathrm{in}}$ ). A note from the main hand in the left margin of fol. $418 \mathrm{v}$ identifies our text as De motibus planetarum secundum Abraham. The colophon on fol. $422 \mathrm{r}$ reads Explicit introitus ad astronomiam. The copy features no diagrams or tables, but adds a long excursus at the end of the description of the orb of the Moon (fol. 420v), which repeats information given earlier in the text, but uses different vocabulary. Hindu-Arabic numerals are used throughout.

$\mathrm{R}=$ Oxford, Bodleian Library, Rawlinson D.893, fols $129 \mathrm{~V}-134 \mathrm{v} .{ }^{82}$

Rawlinson D.893 is a collection of manuscript fragments, where our text appears as part of a 16-page booklet of $215 \times 130 \mathrm{~mm}$. The folio-numbering from 127 to 134 belongs to the consecutive numbering of leaves in the entire fragment collection. In addition, fols 128 to 134 are numbered 1 to 7 . According to a note on fol. 127, the booklet once belonged to a codex of 136 folios. The handwriting is probably from the beginning of the thirteenth century. ${ }^{83}$ It certainly postdates the Ethica vetus version of Aristotle's Nicomachean Ethics, which ends on fol. $128 \mathrm{r}=1 \mathrm{r}$. The Vita Secundi philosophi starting on fol. $128 \mathrm{v}=1 \mathrm{v}$ and ending incompletely on fol. $129 \mathrm{v}=$ $2 \mathrm{v}$ was translated into Latin c. $1167 .^{84} \mathrm{On}$ fol. $130 \mathrm{r}$ and fol. $131 \mathrm{r}$ the scribe placed lines in the margin that needed to be re-inserted after an eye-skip. The margins of fols $131 \mathrm{v}, 132 \mathrm{r}$, and $132 \mathrm{v}$ feature longer glosses that are extraneous to the original text. Diagrams corresponding to Figs. 1-4 appear on fols 130v, 132r, 133r, 134v. There are no tables. Roman numerals are used throughout.

$\mathrm{S}=$ Oxford, Bodleian Library, Selden supra 76, fol. 20r-28r..$^{85}$

This copy is part of an astrological-alchemical anthology from England (126 fols, $215 \times 160 \mathrm{~mm}$ ) written by a single thirteenth-century hand $\left(\mathrm{s} . \mathrm{XIII}^{2 / 2}\right)$. The codex was at the Priory of St Swithun, Winchester, by the early sixteenth century. There are no diagrams included in this copy of our text. A table for the ascending nodes appears in the right margin of fol. 28r. As in E, the Lmp finishes with an appendix

81 David Juste, 'MS Parma, Biblioteca Palatina, 718-720' (update: 24.07.2017), Ptolemaeus Arabus et Latinus. Manuscripts, URL = <http://ptolemaeus.badw.de/ms/146>.

82 William D. Macray, Catalogi Codicum Manuscriptorum Bibliothecae Bodleianae, vol. V.4, Oxford: Clarendon Press, 1898, col. 84.

83 Thomson, The Writings of Robert Grosseteste, p. 235, assigns to $R$ a date in the mid-thirteenth century ('XIII' ${ }^{\mathrm{m}}$ '). Baur, Die philosophischen Werke, p. 61*, had previously written '14. Jahrhundert (?)'.

84 See Ben Edwin Perry, Secundus the Silent Philosopher, Ithaca, NY: American Philological Association, 1964, pp. 23-52.

85 David Juste, 'MS Oxford, Bodleian Library, Selden supra 76' (update: 09.11.2017), Ptolemaeus Arabus et Latinus. Manuscripts, URL = <http://ptolemaeus.badw.de/ms/482>. 
consisting of chapters from al-Khwārizmī's zijj and a shadow table (fols $28 \mathrm{r}-29 \mathrm{v}){ }^{86}$ Roman numerals are used throughout.

$\mathrm{V}=$ Vatican City, Biblioteca Apostolica Vaticana, Pal. lat. 1414, fols 62va-66vb. ${ }^{87}$ This copy belongs to a French codex of 225 fols in double columns $(215 \times 150 \mathrm{~mm})$ written in the second half of the thirteenth century. The $\operatorname{Lmp}$ here carries the heading Incipit theorica planetarum. As with $E$, this copy was made from an exemplar that featured five instead of the usual four diagrams. The scribe of $V$ only completed Fig. 1 (fol. 63r), but left outer circles for four more planetary diagrams on fols 64rb, 65r, 66r, 66vb. The final column (fol. 66vb) features a combined table of apogees and nodes (Tabula geuzahar). The colophon below reads Explicit quedam theorica in motibus septem planetarum. Hindu-Arabic numerals are employed throughout. The manuscript is available online at <http://digi.ub.uniheidelberg.de/diglit/bav_pal_lat_1414>.

$\mathrm{X}=$ Vatican City, Biblioteca Apostolica Vaticana, lat. 3133, fols 20ra-26ra.

This copy belongs to a French codex of 62 fols in double columns written in the fourteenth century. The $\mathrm{Lmp}$ here comes without any ascription or title. Diagrams corresponding to Figs. 1-4 appear on fols 21vb, 23va, 24va, 26ra. Instead of preserving the final paragraph starting Sunt ergo geuzahar etc. (1l. 410-421), X's copy segues into another lengthy geometrical account of the planetary equations (fols $26 \mathrm{rb}-27 \mathrm{vb})$. The copy uses both Roman and Hindu-Arabic numerals.

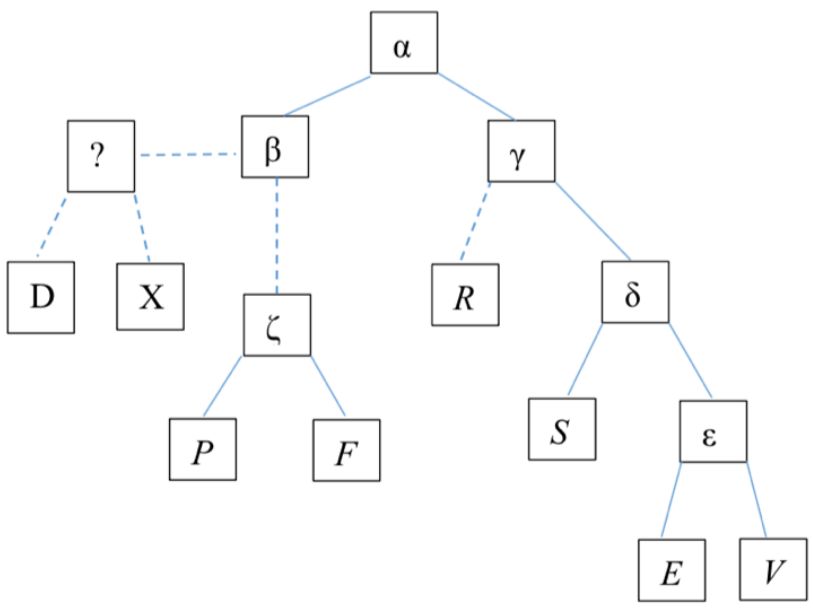

86 See n. 79 above.

87 David Juste, 'MS Vatican, Biblioteca Apostolica Vaticana, Pal. lat. 1414' (update: 16.12.2017), Ptolemaeus Arabus et Latinus. Manuscripts, URL = <http://ptolemaeus.badw.de/ms $/ 239>$. 
Based on the variants shared between them, it is possible to divide the eight complete copies of our text into two separate branches, whose arms appear to converge at sub-archetypes $\beta$ (manuscripts DFPX) and $\gamma$ (manuscripts ERSV). Descendants of $\gamma$ share in common the loss of three passages that are very likely to have belonged to the original text. The first concerns the omission of deinde luna recedit ... in directo augis as a result of homeoarchy (in directo augis in 11.157 and 162). The repeatable nature of this error explains why it also appears in $P$, but not in its close relative $F$. The second passage lost in ERSV is the sentence that defines the diameter-increment of the Moon (ll. 184-187: 'Equatio diversitatis diametri circuli brevis ... per centrum epicicli'). The reasons for this omission are not entirely clear, but they may have to do with the fact that the definition given here really pertains to the equation of centre (equatio puncti), not to the diameter-increment (see section II above). The third case concerns a sentence in 11. 268-270: 'Secundum istum etiam circulum consideratur augis Mercurii, quia in directo illius <partis excentrici equantis motum qui remotior est a centro terre est augis> Mercurii in circulo signorum'. Here, the words between <...> have dropped out. In addition to these omissions, sub-archetype $\gamma$ introduced into our text two substantial passages that were still absent in the original recension. The first occurs at the end of the description of the orb model for Mercury (1.303) and amounts to a geometrical proof as to why the equation of anomaly will reach a maximum when the true anomaly is slightly above $90^{\circ}$ and below $270^{\circ}$ :

Demonstratio quod maior appareat linea a contingente in contingentem ducta quam diametrus circuli. Unde maior est equatio partis sub diametro circa lineam contingentem et sub illa erit quedam diametro equali in apparentia. Sit A terra, $\mathrm{H}$ centrum brevis circuli ${ }^{88} \mathrm{BDFGEC}$, linea contingens $\mathrm{AE}$, et tunc $\mathrm{AD}$, est linea ad diametrum $A C$ et item $A B$. Angulus vero DAE maior est angulo BAC et que sub maiori angulo videntur maiora apparent. Maior ergo apparet linea $D E$ quam diametrum $\mathrm{BC}^{89}$ cui equalis apparet $\mathrm{FG}$, quia que sub equali angulo vel eodem apparent equalia videntur. ${ }^{90}$ Dicitur ${ }^{91}$ omnis planeta esse in celo ubi linea exiens a centro terre per planetam ducta celum tangit. Hec ideo facta sunt cum videatur maxima debere esse equatio partis circa tria signa vel cum $^{92}$ est ultra tria et infra IX et similiter de diversitate diametri.

Two of the four manuscripts, $R$ (fol. $6 \mathrm{r}$ ) and $E$ (fol. 117v), include a geometrical diagram corresponding to the explanation given in this paragraph, but neither this diagram nor the text itself give the impression that they belong to the $\mathrm{Lmp}$ in its

88 centrum brevis circuli] brevis circuli centrum $S$

89 diametrum $\mathrm{BC}$ ] dyameter $\mathrm{AB} V$

90 vel ... videntur] videntur vel eodem equalia apparent $V$

91 Dicitur] add. autem $V$

92 cum] IX S 
original form. That we are dealing with an interpolation is clear from the vocabulary, as the text starting with Demonstratio quod uses the term equatio partis to refer to the equation of anomaly. This is reminiscent of the Toledan Tables and Scito quod annus solaris, which both switch between pars and portio when referring to the anomalies of the Moon and the five planets. ${ }^{93}$ The $\mathrm{Lmp}$, however, is otherwise consistent in using portio, which renders the paragraph suspicious.

The second passage exclusive to the $\gamma$-branch comes right after the Lmp's summary of the elements shared by the models of all five planets (1. 244: 'Hec quidem communia sunt omnibus quinque'). Manuscripts DFPX move on immediately to discuss the features particular to Mercury, whereas ERSV pause to point out that the diameter-increment added to the equation of anomaly is always positive in the case of the Moon, but can be positive or negative in the case of the five planets:

[Hec quidem communia sunt omnibus quinque], nisi quod equatio diversitatis diametri equata in luna semper additur equationi partis, in ceteris cum fuerit planeta in superiori parte excentrici circuli minuitur, in inferiori ${ }^{94}$ additur. Quod ideo fit, quia philosophi ordinaverunt quantitates linearum in epiciclo lune, que dicuntur 'equationes portionis', cum fuerit luna in auge excentrici. Unde, cum linee ille semper alibi appareant maiores, erit semper addendum quod sumitur de diversitate diametri, que est $\mathrm{id}^{95}$ quo quelibet linea epicicli maior apparet in longitudine propiori ${ }^{96}$ quam longiori, ${ }^{97}$ de quibus semper addendum est secundum minuta proportionalia. In ceteris autem planetis ordinatio ista ${ }^{98}$ facta fuit ${ }^{99}$ in medio excentrici inter longitudinem longiorem et propiorem. Unde sunt ibi longitudines longiores et propiores. Longitudines vero longiores sunt minuende, longitudines vero propiores addende secundum minuta proportionalia. Et est planeta in longitudine longiori a tribus signis ab auge et ultra IX, a tribus autem usque ad novem in propiori, unde secundum talem cuspidem summenda est longitudo longior vel propior.

As in the previous instance, we here encounter equatio partis as a term for the lunar equation of anomaly, which is familiar from Scito quod annus lunaris, but seems out of place in the Lmp. A more important reason for excluding the passage, however, is that it fails to cohere with the text that comes before it. The passage that precedes the one just cited lists some of the elements that the models for the three superior and two inferior planets all share in common. The phrase 'Hec quidem

93 See n. 64.

94 inferiori] superiori ERS

95 illud] om. S

6 propiori] longiori ERSV

97 longiori] propiori ERSV

98 ista] ita $E V$

99 facta fuit] fuit facta $R$ 
communia sunt omnibus quinque' underlines this common ground as a way of prefacing the following discussion of Mercury, whose model differs in some respects from that of the other four planets. The additional passage in ERSV instead gives the misleading impression that the model of the Moon was supposed to be included in omnibus quinque and that this is the reason why the claim 'Hec quidem communia sunt omnibus' would be in need of some qualification. This is not the case and a comparison of the diameter-increments of the Moon and the planets is irrelevant at this stage of the discussion.

It may be worth noting that the earliest known representive of the $\gamma$-branch, $R$ (fol. $5 \mathrm{v}$ ), contains the aforementioned addition as a marginal gloss, although one that was marked for insertion into the main text. The other three manuscripts, $E S V$, can be linked to their shared ancestor $\gamma$ via two sub-archetypes. One of these, labelled $\delta$ in the stemma below, came before $E$ and $S$. Both copies merge the Lmp with several chapters from Adelard of Bath's translation of the zij of al-Khwārizmī, which deal with oblique ascensions as well as with the relation between the Sun's altitude and the length of a shadow. Between $\delta$ and $E$ one must postulate at least one more node, occupied by $\varepsilon$, which introduced several variants common to $E$ and $V$. One of the more conspicuous additions that passed from $\varepsilon$ to $E V$ was a table of apogees, which the latter two copies place above the table for the longitudes of the ascending nodes. In addition to inserting this table, the scribe responsible for $\varepsilon$ made an effort to repair the passage in 1l. 383-389, which was supposed to quantify the four motions of Mercury. Only one of the eight relevant manuscripts, $D$ (fol. $142 \mathrm{r}$ ), shows this text in a form that may come close to what was originally intended:

Mercurius equidem quatuor habet motus: unum quo corpus planete movetur in suo epiciclo, in superiori quidem parte ab occidente in orientem, <in inferiori econverso omni die tribus gradibus et 6 minutis. Alium quo centrum epicicli in circumferencia excentrici rotatur ab occidente in orientem $>$ uno gradu et $\mathrm{LVIII}^{100}$ minutis. Tertium quo centrum excentrici deferentis centrum epicicli movetur ab oriente in occidentem LIX minutis et VIII ${ }^{101}$ secundis. Quartum vero communem cum spera stellarum fixarum.

The passage must have read differently in $\gamma$, where the part marked by $<. . .>$ had disappeared due to an eye-skip triggered by the recurrence of the phrase $a b$ occidente in orientem. This caused the text to undergo a contraction in which the rate of the second of Mercury's motions $\left(1 ; 58^{\circ} / \mathrm{d}\right)$ ended up being assigned to the first motion (of the epicycle), while the second motion itself disappeared from the discussion altogether ('unum quo corpus planete in suo movetur epiciclo, in

100 LVIII] $58 D$

101 VIII] 4 DP 
superiori quidem parte $a b$ occidente in orientem uno gradu et LVIII minutis. Tertium autem etc.'). The results of this contraction are still seen in RS, whereas the scribe of $\varepsilon$ sought to restore the lost information by inserting a new sentence after LVIII minutis, which in all manuscripts other than D is corrupted to LVIII (or 58) secundis: 'Secundum quo centrum epicicli simul cum epiciclo rotatur ab occidente in orientem in circumferentia ecentrici deferentis epiciclum' ( $E$, fol. $118 \mathrm{v} ; \mathrm{V}$, fol. $66 \mathrm{va}$ ). His attempt was succesful as far as the basic characterization of the second motion was concerned, but he was unable to supply quantitative information, not realizing that the preceding uno gradu et LVIII minutis should have belonged to the second rather than the first motion. ${ }^{102}$

A similar state of affairs presents itself for the remaining three copies, FPX, which descend from $\beta$ rather than from $\gamma$. Of these, $P$ displays the passage in the same contracted form as $R S$, whereas $F$ and $X$ each reflect different attempts to fill the gap in the text's logic. The more coherent of these attempts is found in $X$ (fol. $25 \mathrm{vb}$ ), where uno gradu et 58 secundis [!] is followed by: 'Secundus motus est quo centrum epicicli movetur in circumferencia ecentrici deferentis ab occidente in orientem pertranseundo singulis dierum 59 minuta et 8 secunda de circumferencia ecentrici equantis motum'. What makes this obvious interpolation in $X$ surprising is that the manuscript otherwise shares significant variants with $D$, which makes it plausible that both manuscripts derive from the same sub-archetype, which omitted the passage drawn from Walcher of Malvern (1l. 104-109) as well as the text's final paragraph and corresponding table dealing with the nodes and latitudes of the five planets (11. 410-421). The fact that $D$, but not $X$, presents the passage on Mercury's four motions in a plausible and numerically correct version may speak against this hypothesis, but the remainder of $D$ contains enough interpolations and emendations to suggest that the scribe in question may have possessed the competence and sound intuition required to reconstruct the passage from a faulty exemplar. The problem remains that the variants in DFPX do not paint a clear picture of the relationship between these four manuscripts. At most, one may conclude that FP go back to a sub-archetype, $\zeta$, which is at some remove from the sub-archetype $\beta$ that links FP to DX. The broken lines used in the stemma above reflect a degree of uncertainty about the precise relation between the manuscripts in this group.

Like the text itself, the four diagrams described in the $\operatorname{Lmp}$ (11. 65-79, 201-225, 271-303, 332-360) have been preserved in an imperfect state. Two copies (SP) omit diagrams altogether, while the remaining six (DEFRVX) reproduce Figs. 1-4 to varying degrees of faithfulness. From the drawings in EV it appears that subarchetype $\varepsilon$ contained five rather than just four diagrams. In the case of $E$, only the

102 Compare the motion rates stated in ch. 14 of al-Farghānīs Elements: Carmody, Al Farghani, pp. 2728; Campani, Alfragano, p. 123. 
geometrical elements of these diagrams are well preserved, whereas point labels and equation lines are missing from Figs. $2-4$ as well as from the fifth diagram on fol. $118 \mathrm{v}$, which seems to repeat the structural outlines of Fig. 4, but with the equant circle shifted downwards, so as to pass through the apogee of the epicycle at point N. The scribe of $V$ only completed Fig. 1 (fol. 63r), leaving outer circles for the remaining four diagrams. For the purpose of the edition below, I have made an attempt to reconstruct the four authentic diagrams in accordance with the precise specifications given in the text. Some additional cues have been derived from the way the diagrams were drawn in manuscripts $R$ and $X$, which appear to offer the best representation of what might have been included in the joint archetype. This recourse to the manuscripts was necessary in particular for the (grey) lines representing the planetary equations, which the text does not describe in any detail.

For Fig. 1, which appears at the end of the section on the motion of the Sun (after 1. 109), I have closely followed the structural template provided by $R$ (fol. $130 \mathrm{v}$ ). In manuscript $X$ (fol. 21v) the diagram stands on its head, being turned by $180^{\circ}$. The scribe here added descriptive labels to the diagram, which mark the locations of the oppositum augis, the centrum terre, the centrum excentrici, and the aux solis. The same manuscript contains an interpolated passage that explains the solar equation on the basis of Fig. 1. It mentions a number of additional points $(R, S$, and $T$ ) that are duly marked in X's version of this diagram. ${ }^{103} \mathrm{~F}$ (fol. 108va) differs from the other copies in drawing the disk of the Sun at four positions inside the deferent, which similar to Figs. 2-4 is represented by three concentric circles rather than just one. Also, the diagram is here tilted by $90^{\circ}$ to the left and comes with descriptive labels that identify the individual circles as well as the four directions (assigning oriens to point $\mathrm{D}$, meridies to $\mathrm{C}$, occidens to $\mathrm{B}$, and septemtrio to A). The order in which the points on each circle are labelled is different in $V$ (fol. 63r), which offers equation lines only for the two cases of the Sun being in the topleft and bottom-right quadrant (slightly above and below the diameter). The

${ }^{103} X$ (fol. 21r): 'Ponamus itaque solem in circulo sue augis descendentem ab auge per medium cursum suum super punctum $R$ et protrahamus duas lineas, unam a puncto $E$, qui est punctus terre, et aliam a puncto $Q$, qui est punctus circuli augis, ad circumferenciam circuli signorum, que abscindant se super punctum $\mathrm{R}$, qui est punctus solis, et terminentur in circulo signorum in $\mathrm{T}$ et $S$. Distancia autem que est inter $T$ et $C$ est equatio que est aggreganda medio cursui vel minuenda $\mathrm{ab}$ eo. Sed quia volumus certificare in circulo signorum, in directo cuius sit sol secundum visum nostrum in circulo sue augis, et linea $\mathrm{Q}$ et $\mathrm{S}$, que exit a puncto circuli augis, ostendit nobis solem maiorem partem accepisse de circulo signorum quam linea ET, que exit a puncto terre, ideo minuimus de medio cursu, ut per hoc certificatus sit locus solis secundum visum nostrum in circulo signorum. Si autem sic protraxeris lineas in qualibet quarta circuli videbis quod quando argumentum solis est minus 6 signis tunc debes minuere et quando maius debes aggregare. Quando vero sol est in sua auge vel in opposito nulla est equatio, quia linee ab utriusque protracte per locum augis et per oppositum nullam faciunt diversitatem signorum.' 
diagram is here endowed with an outer ring depicting the names of the twelve zodiacal signs. The apogee resides in Gemini, in accordance with the text (1.397). Another version that shows the zodiacal signs appears in $D$ (fol. 139r), but here the apogee is placed between Gemini and Cancer rather than in Gemini itself.

My reconstruction of Fig. 2 (after 1. 225) is nearly identical to the way the diagram is represented in $X$ (fol. 23v), which shows the equation of anomaly for two possible positions of the Moon on each of the four epicycles depicted. $D$ (fol. 140r) lacks equation lines and follows a different order of point labels. The point labels go anticlockwise in $R$ (fol. 132r), which also has fewer equation lines. The lines going in the direction of points $D$ and $B$ here only show the equation of centre, while those towards $A$ and C only deal with the equation of anomaly. In $F$ (fol. 109v), the point labels are arranged similarly to $R$, but in addition this copy adds small circles on the circumference of the epicycles representing the body of the Moon and adorns the diagram with a number of descriptive labels. One of these marks an equant circle (equans motum) that the scribe misleadingly included in analogy to Figs. 3 and 4.

None of the preserved manuscripts offer a fully satisfactory rendition of Fig. 3. The one that comes closest to the reconstruction inserted below (after 1. 303) is that in $X$ (fol. $24 \mathrm{v}$ ), which lacks the equation lines expressly mentioned in the text (11. 300-303) and fails to place $E$ (the centre of the Earth) at the centre of the circle representing the inner surface of the orb of Mercury. According to the preserved text, the letter $\mathrm{F}$ is supposed to indicate the apogee of both the epicycle (1l. 291, 294) and the equant circle (1.300). In order to avoid confusion, I have reserved capital $\mathrm{F}$ for the epicycle and used lower case $f$ for the equant circle. None of the preserved drawings include the second of these points, nor does any of them mark $T$ for the epicycle's perigee (1.296). $R$ (fol. 133r) preserves a few of the equation lines, but is otherwise imperfectly drawn. In $F$ (fol. 110v), there are a few descriptive labels for the figura verissima Mercurii, but no equation lines and no circle that would represent the deferent of centre $Q$ around $I$. The rendition in $D$ (fol. 141r) remains skeletal.

Similar to Fig. 3, the best rendition of Fig. 4 appears in X (fol. 26r), discounting the fact that this version features several additional point labels not mentioned in the text and omits the o-shapes the author wanted to be placed on the equant circle (1l. 338-341). In $R$ (fol. 134v), the point labels correspond more closely to what is specified in the text and displayed in the reconstruction below (after 1. 360), but neither the circles nor the equant lines were properly or fully implemented. $F$ (fol. $111 v)$ lacks equation lines, but was more successful in carrying out the geometrical part and offered some descriptive labels for points $Q, I$, and $E$ (equantis, deferentis, and mundi). An attempt to draw the same diagram in $D$ (fol. 141v) remained abortive. 
The edition below will be based on all eight full copies of the text, DEFPRSVX. It will not take into account the heavily truncated text in $B$, which may be a descendant of $\varepsilon$. Due to the high incidence of variants between the surviving witnesses, a full collation, which would have generated an apparatus of over 2000 entries (compared to a main text of fewer than 4500 words), seemed undesirable. In an effort to reduce the 'noise' produced by insignificant variants, the apparatus printed below will omit minor variants that are unique to one manuscript and instead focus on variants shared by two or more witnesses. It will also exclude major interpolations, such as the two passages in ERSV quoted and discussed above, if it is obvious that they are extraneous to the original text. 


\section{Liber de motibus planetarum}

Investigantibus astronomie rationes primo ponendum est punctos esse septem et lineas tres et circulos tres. Ponamus itaque primum punctum esse in oriente, ${ }^{1}$ secundum in occidente, tertium in austro, quartum in septemtrione, quintum in medio celi, sextum in angulo terre. Septimus ${ }^{2}$ est punctus ${ }^{3}$ terre.

Prima linea est $a b$ orientali puncto per punctum terre ad occidentalem, secunda ${ }^{4}$ ab australi ad septemtrionalem ${ }^{5}$ per punctum terre similiter, tertia ${ }^{6}$ vero a puncto medii celi per punctum terre ad punctum anguli terre.

Primus circulus est ab orientali puncto per punctum medii celi et per punctum occidentis et per punctum anguli terre donec eius determinatio ${ }^{7}$ fiat in puncto orientali a quo incipit. ${ }^{8}$ Et hic est 'circulus directus'. Secundus circulus est a puncto australi per punctum medii celi et per punctum septemtrionis et per punctum anguli terre donec iterum perveniat ad australem punctum a quo originem duxit.

15 Et hic est circulus meridianus, et a quibusdam 'circulus recessionis' dicitur. Tertius vero circulus est a puncto orientali per australem et per occidentalem et per septemtrionalem donec eius terminus iterum fiat ${ }^{9}$ in oriente. Et hic est circulus hemisperii et dicitur 'orizon'. Et punctus terre est centrum horum trium circulorum.

20 Nota quod unusquisque istorum circulorum divisus est in quatuor partes equales. Et in qualibet quarta sunt XC gradus, quia quilibet circulus CCCLX gradus continet. Circuli autem ab hemisperio incipientes et abscindentes circulum directum et circulum meridianum, quorum determinatio fit in puncto medii celi, qui punctus dicitur 'zimzalraz', 10 dicuntur 'almucantarath', id est solis 25 progressiones. Et linee ab hemisperio exeuntes et almucantarath abscindentes et in puncto medii celi metam facientes sunt 'azimuz', ${ }^{11}$ id est mensurationes.

Novem autem sunt spere, septem quidem septem planetarum erraticorum, octava stellarum fixarum. Nona est firmamentum que omnes alias infra se concludit. ${ }^{12}$

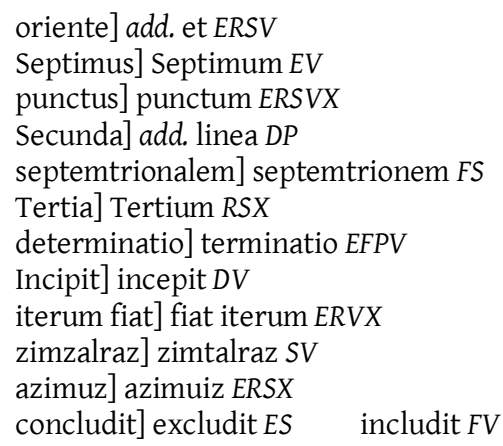


Restat igitur de motibus planetarum tractare in speris suis, et prius ${ }^{13}$ incipiendum a sole, qui in medio planetarum quasi rex in medio regni sui ${ }^{14}$ locatus principatum tenet, quia in prima mundi creatione Deus ante ceteras stellas luminare maius, solem scilicet, ${ }^{15}$ ut preesset diei, et luminare minus, id est ${ }^{16}$ lunam, ut preesset nocti, creavit [Genesis 1:16].

Sol itaque secundum auctoritatem philosophorum duos habet motus, quorum primus est essentialis ab occidente in orientem in suo excentrico circulo ${ }^{17}$ unaquaque die LIX minutis et VIII secundis. Secundus motus solis est secundum 40 quantitatem spere stellarum fixarum, hoc est in centum annis uno gradu. Sicut enim spera stellarum fixarum ${ }^{18}$ in omnibus centum annis uno gradu movetur versus orientem vel occidentem super axes circuli signorum, sic spera solis in centum annis uno gradu movetur. Et nota quod octava spera ab initio Arietis movetur ante, id est versus orientem, ${ }^{19}$ VIII gradibus usque ad XXII gradum

45 Piscium, et inde revertitur et movetur iterum ab initio Arietis retro, id est versus occidentem, totidem gradibus, id est VIII, et rursum versus orientem. ${ }^{20}$ Unde 'circulus accessionis et recessionis' dicitur. Ex hiis duobus motibus locus solis certificatur in circulo signorum. ${ }^{21}$

Nota autem ${ }^{22}$ quod planeta habet circulum extrinsecum ${ }^{23}$ et circulum similem

50 circulo signorum. Et hii duo unum sunt. Omnis enim circulus duas habet superficies, unam superius et alteram inferius, inter quas continetur spissitudo circuli, in qua spissitudine planete moventur. Et aliquando motus eorum ad superficiem superiorem ${ }^{24}$ circuli tendit, ${ }^{25}$ aliquando ad inferiorem, et propter diversitatem huius motus dicuntur habere excentricos, quia extra centrum terre

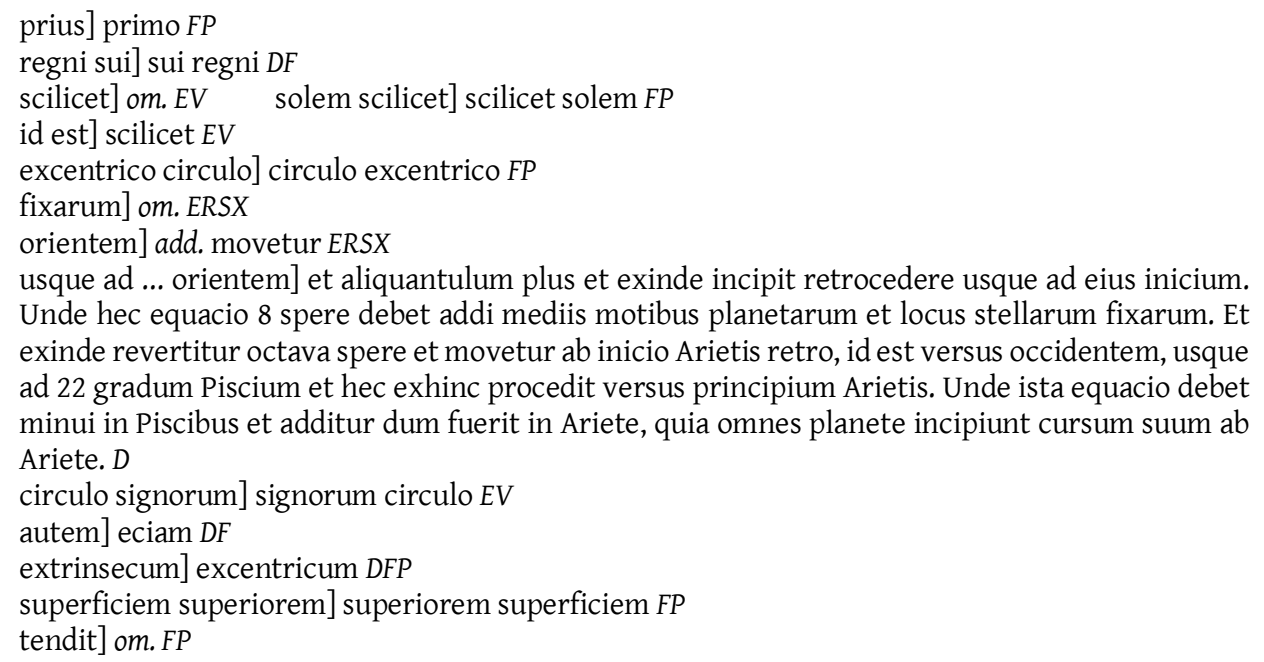


55 moventur. Centrum excentrici circuli solis ${ }^{26}$ secundum quod sapientes probaverunt distat a centro terre secundum maioris quantitatem equationis solis in circulo signorum, id est per spatium unius gradus et LIX minutorum et $\mathrm{X}$ secundorum.

Medius cursus planete est quantum vadit planeta in suo excentrico circulo in quolibet determinato tempore incipiens ab Ariete. Halissa ${ }^{27}$ vero solis est spatium quod est inter augem et solem quod remanet quando minuimus augem, id est duo signa et XVII gradus et L minuta, de medio cursu solis. Equatio solis est distantia capitum $^{28}$ duarum linearum in circulo signorum, quarum una exit a centro terre ${ }^{29}$ et alia a centro excentrici circuli per corpus solis in excentrico.

65 Nunc ad maiorem evidentiam in figura geometrica predicta attendere oportet. Faciamus igitur circulum signorum $A B C D$ super centrum $E$ divisum in quatuor partes equales cum duabus diametris abscindentibus ${ }^{30}$ se super punctum E. Item ${ }^{31}$ faciamus circulum similem circulo signorum FGHI super idem centrum, qui ostendit superficiem superiorem ${ }^{32}$ circuli solis, ${ }^{33}$ qui vocatur 'circulus augis', et 70 alium faciamus citra ${ }^{34}$ circulum similem huic, qui sit KLMN, qui ostendit inferiorem superficiem circuli solis, qui vocatur 'circulus oppositi ${ }^{35}$ augis'. Circuli enim similes dicuntur qui super eundem punctum volvuntur. Item ${ }^{36}$ faciamus alium circulum inter hos duos circulos, qui contingat utramque ${ }^{37}$ superficiem circuli solis super centrum $Q$, qui circulus sit FOMP, qui est circulus excentricus et est circulus medii 75 cursus solis. Spissitudo circuli ${ }^{38}$ est ab inferiori superficie usque ad superiorem. 'Augis' autem sive 'longitudo longior' vocatur ubi excentricus contingit superiorem $^{39}$ superficiem super punctum $\mathrm{F}$, 'oppositum ${ }^{40}$ vero 'augis' ubi ${ }^{41}$ contingit inferiorem superficiem super punctum ${ }^{42} \mathrm{M}$, et dicitur alio nomine 'longitudo propior'. ${ }^{43}$

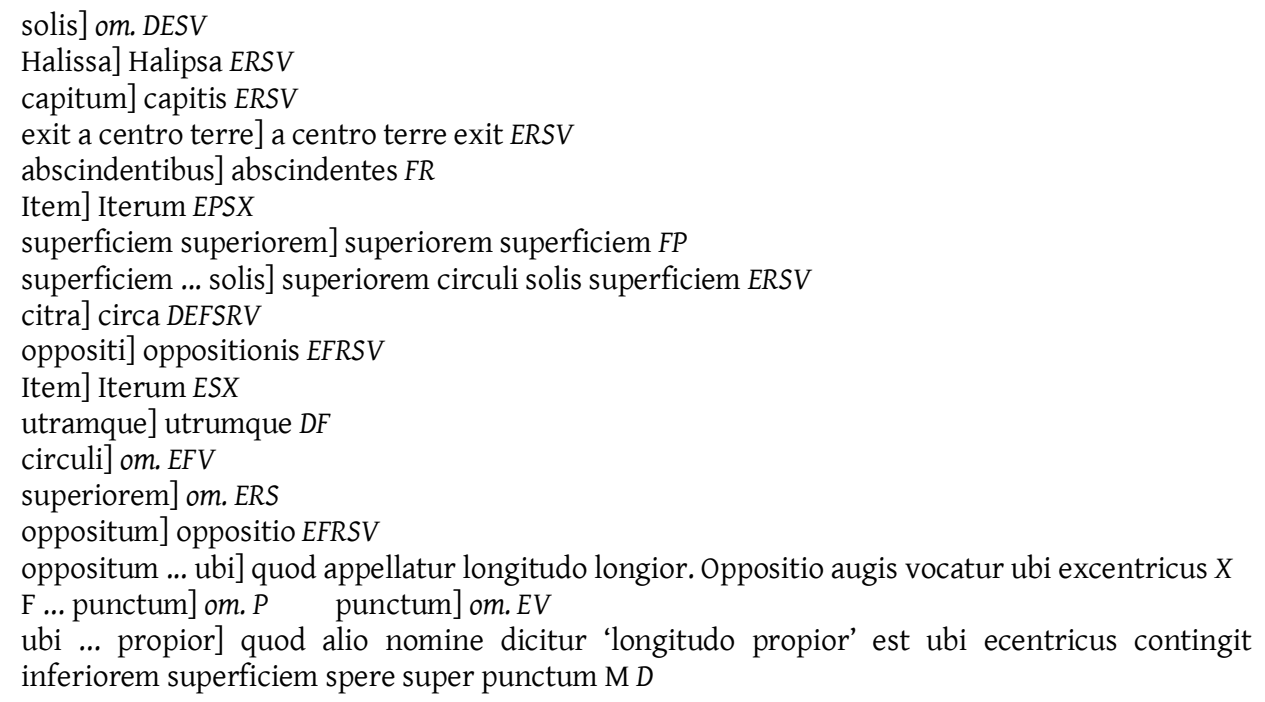


Hiis itaque prelibatis ostendamus quare solis equatio, quando portio eius, id est halissa, ${ }^{44}$ minor est $\mathrm{t}^{45} \mathrm{VI}$ signis, minuenda est de medio cursu solis, et quando portio est maior, addenda est super medium cursum. Halissa ${ }^{46}$ itaque, sive portio solis, est illud quod remanet quando minuimus augem solis, id est duo signa, XVII gradus et L minuta, ${ }^{47}$ de medio cursu solis. Si ergo per corpus solis in suo excentrico due linee protrahantur ad circulum signorum, quarum una egrediatur a centro terre et alia a centro excentrici circuli, si quidem sit a longitudine longiori usque ad longitudinem propiorem linea exiens a centro excentrici maius spatium occupat de circulo signorum quam linea exiens a centro circuli signorum, quod est centrum terre. Unde equatio solis tunc est minuenda ${ }^{48}$ de medio cursu, quoniam locus solis 90 examinatur in circulo signorum secundum lineam que dirigitur a centro terre per corpus solis ad circulum signorum. Si vero fuerit sol a longitudine propiori usque ad longiorem, linea exiens a centro excentrici circuli ad circulum signorum minus spatium occupat de circulo signorum quam linea exiens ${ }^{49}$ a centro terre abscindens illam super corpus solis. Unde equatio solis tunc est addenda super medium 95 cursum solis. Si vero fuerit in longitudine ${ }^{50}$ longiori vel propiori, nulla est ${ }^{51}$ equatio, quoniam eadem est linea que exit a centro terre et que exit a centro excentrici. Unde tunc medius cursus solis est locus solis certificatus in circulo signorum.

Et nota quod sol ex utraque parte sue augis per spatium trium signorum minus medio cursu suo vadit et tardius movetur, ab utraque vero parte oppositi augis per 100 spatium trium signorum ${ }^{52}$ citius movetur et plus medio cursu suo perambulat. Quod ostendit diametrus, id est linea dividens excentricum circulum per medium, quoniam maiorem partem circuli signorum inferius, minorem vero superius comprehendit. ${ }^{33}$

Dicunt autem quidam doctorum quod sol in DCCCC annis citius movetur per $105 \mathrm{VII}^{54}$ gradus et in aliis DCCCC tardius per VII ${ }^{55}$ similiter gradus, et nos modo sumus in tardiori, unde dicitur moveri in CCCLXV diebus et VI horis CCCLIX gradus, ${ }^{56} \mathrm{LIX}$

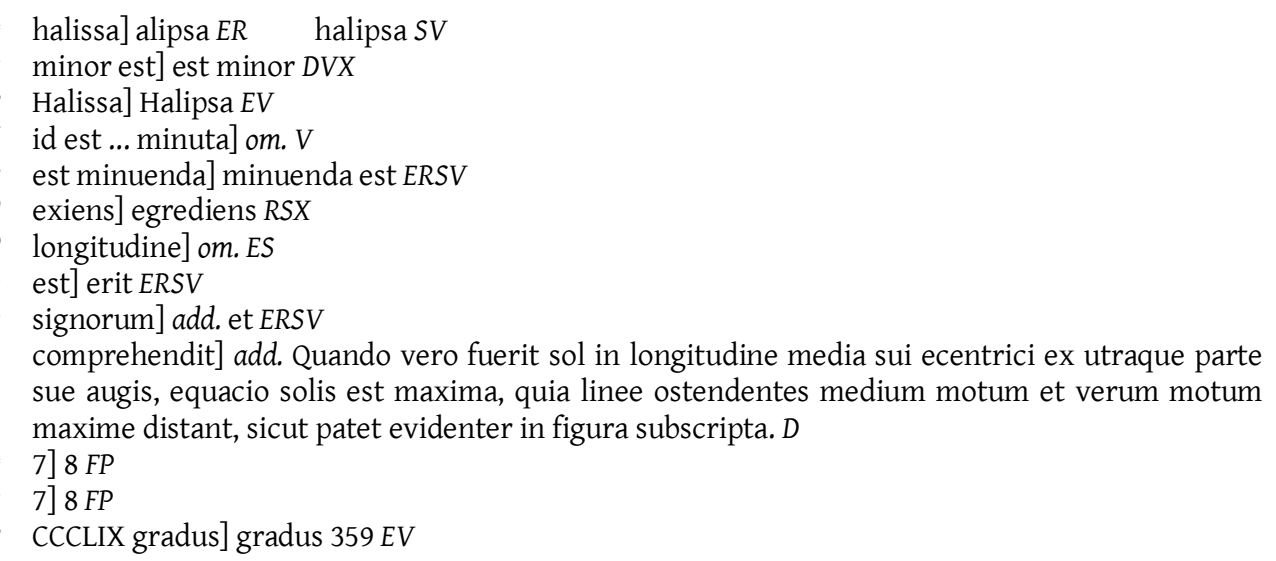


punctos, ${ }^{57}$ LVI minutias ${ }^{58}$ XIX minutias minutiarum. ${ }^{59}$ Desunt adhuc de zodiaco III minutie $^{60}$ et XLI minutie minutiarum ${ }^{61}$ hancque dicunt esse causam mutationis solstitiorum et equinoctiorum. ${ }^{62}$

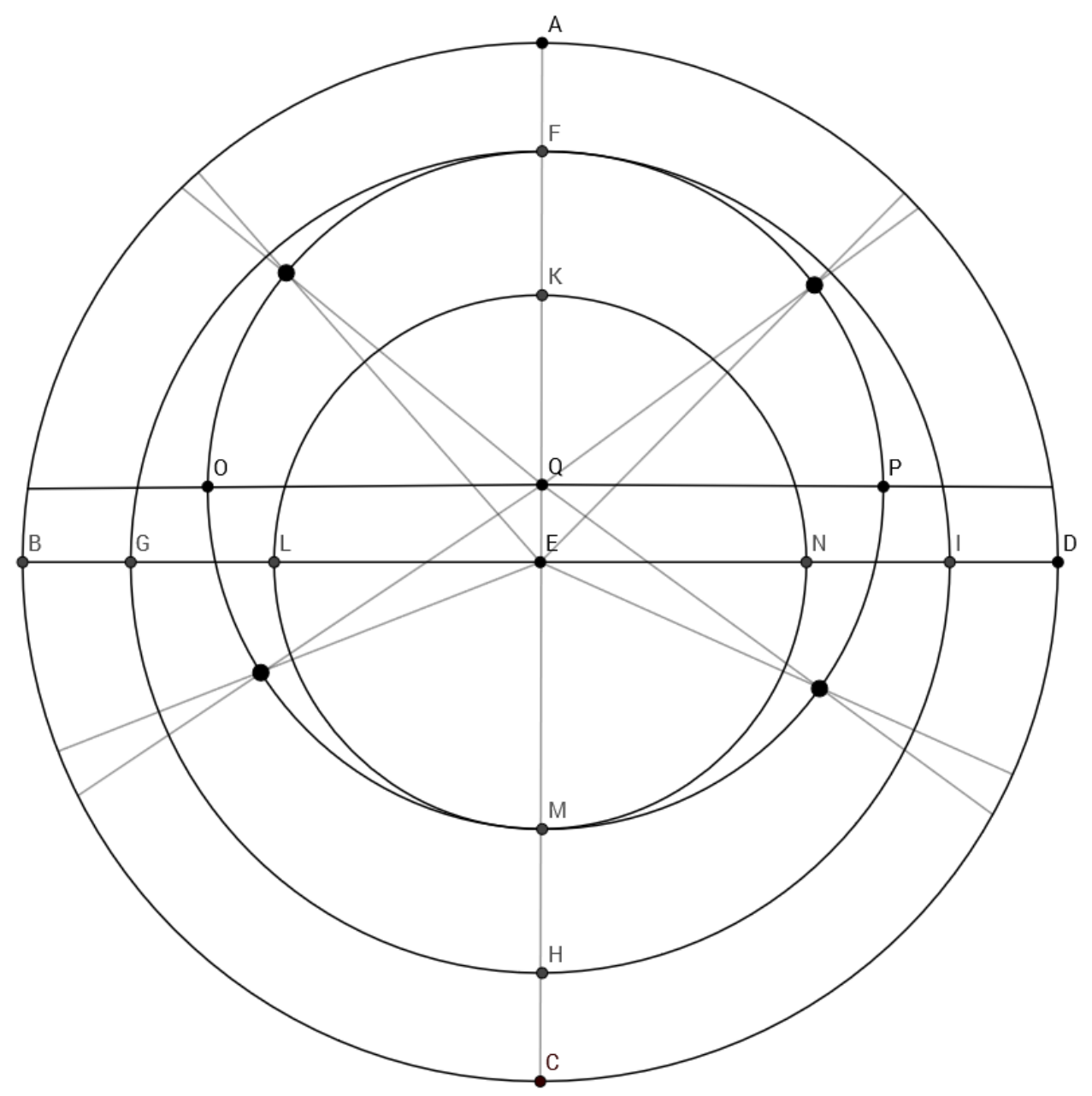

Fig. 1: Figura spere solis

\footnotetext{
LIX punctos] om. EV LIX minuta RS

LVI minutias] secunda $56 \mathrm{EV} \quad$ LVI secunda RS

XIX minutias minutiarum] tertia $19 \mathrm{EV} \quad$ XIX tertia RS

III minutie] tria secunda RS 3 secunda $E F V$

minutie minutiarum] tertia ERSV

Dicunt ... equinoctiorum] om. DX
} 
$<$ De motu lune $>$

Post tractatum luminaris maioris, id est solis, sequitur tractatus luminaris minoris, id est lune, cui quinque motus secundum diversitatem centrorum et circulorum a sapientibus assignantur. Quorum primus est corporis lunaris in epiciclo suo, id est 115 circulo suo brevi, in quo movetur luna in superiori parte ab oriente in occidentem. Et tunc dicitur cursu tardior, quia videtur quasi retrogradari. In inferiori vero parte eiusdem epicicli movetur ab occidente in orientem. Et tunc est cursu velocior, quia est aucta numero. In superiori ${ }^{63}$ vero parte minuitur numero. Luna dicitur 'aucta numero' quando equatio portionis equata medio cursui eius aggregatur, 'minuta' 120 quando minuitur. Similiter dicitur luna 'aucta lumine' et 'minuta', 'aucta' quando separatur a sole, quia tunc crescit lumen eius, 'minuta' quando ab oppositione recedit et appropinquat soli.

Secundus motus lune est in circulo excentrico, in quo centrum epicicli ab occidente in orientem movetur. Qui motus lune attribuitur, quia per motum centri 125 epicicli in excentrico circulo movetur epiciclus ab occidente in orientem, in quo movetur luna suo motu naturali.

Tertius est circulus parvus cuius centrum est circuli signorum, id est centrum terre, in cuius circumferentia movetur excentrici circuli centrum ab oriente in occidentem, contra motum scilicet ${ }^{64}$ centri epicicli. Qui motus assignatur lune, quia 130 movet secum in rotunditatem ab oriente in occidentem excentricum circulum, in quo movetur centrum epicicli et luna ${ }^{65}$ in epiciclo essentialiter.

Quartus motus lune est in circulo simili circulo signorum. Est autem circulus circulo signorum similis circulus habens duas superficies, superiorem et inferiorem, equaliter $a b$ omni parte distantes a centro terre, in cuius medio 135 continetur circulus excentricus, qui declive positus est in spissitudine circuli lune similis circulo signorum. Iste igitur circulus latitudinem habet a septemtrione in meridiem, sed in medio sui, in directo scilicet ${ }^{66}$ circuli signorum, id est zodiaci, habet circulum quendam qui non declinat usquam a zodiaco. Iste itaque circulus positus in directo zodiaci abscindit excentricum circulum lune in duobus locis

140 oppositis, qui dicuntur 'caput' et 'cauda'. Et declinat iste excentricus a predicto circulo qui est similis circulo signorum sicut et a circulo signorum versus septemtrionem et meridiem. Impetuositate ergo tam firmamenti quam excentrici movetur circulus similis circulo signorum tarde ab oriente in occidentem et moventur predicte abscisiones similiter contra successionem signorum, qui motus 145 attribuitur lune.

3 In superiori] Inferiori $P X$

64 scilicet] id est ESV

65 luna] lunam ERSV

66 scilicet] om. FP 
Quintus motus lune est similis motui stellarum fixarum quo in omnibus centum annis uno gradu movetur ante vel retro. Hii sunt quinque motus lune quibus examinatur locus lune in circulo signorum.

Medius autem cursus lune, sicut aliorum planetarum, est spatium inter caput

150 Arietis et corpus lune in excentrico circulo. Et ut evidentius dicamus, medius cursus lune est quantum vadit centrum epicicli versus orientem de gradibus circuli similis circulo signorum, incipiens ab Ariete. Augis lune est longitudo longior excentrici circuli, id est locus in excentrico ubi luna remotior est a centro terre. Et nota quod cum auges omnium aliorum planetarum sint immobiles, nisi quantum

155 in centum annis cum omnibus speris moventur, augis lune movetur cottidie ${ }^{67}$ et volvitur $\mathrm{ab}$ oriente in occidentem eadem quantitate qua luna recedit a sole $\mathrm{ab}$ occidente versus orientem, ita ${ }^{68}$ ut cum luna fuerit iuncta soli sit in directo augis, deinde luna recedit a sole versus orientem, augis vero versus occidentem quantitate eadem, et cum luna fuerit ad oppositum solis sit similiter in directo

160 augis. ${ }^{69}$ Postea luna movetur versus solem ad occidentem, augis etiam lune soli appropinquat ad orientem, et sic semper ${ }^{70}$ luna sit iuncta soli vel opposita in auge sive $^{71}$ in directo augis.

Illud tamen non est pretereundum quod luna citius movetur quam augis quantum sol movetur. Positum siquidem sit $^{72}$ solem et lunam et augem iungi in 165 primo gradu Arietis separeturque luna a sole XII gradibus. Sol quoque interim unum gradum perlabitur. Distat igitur luna a sole XI gradibus, sed et augis tantumdem distat a sole, quare a primo gradu Arietis non perambulavit XI gradus, ${ }^{73}$ ut luna ${ }^{74}$ sed $\mathrm{X}$ tantum. ${ }^{75}$ Unde longitudo lune simplex est spatium quod est inter solem et lunam. Longitudo vero duplex est spatium quod est inter augem lune et 170 lunam. Et ut evidentius dicatur: longitudo simplex est spatium inter corpus solis et centrum epicicli lune in excentrico circulo lune secundum successionem signorum. Longitudo duplex est spatium inter augem lune et centrum epicicli lune in excentrico circulo.

Portio lune simplex est spatium in circumferentia epicicli inter corpus lune et 175 longitudinem longiorem epicicli ad quam dirigitur linea a centro quodam, quod est inter longitudinem propiorem excentrici et centrum terre. Hoc autem centrum semper est in opposita parte centri excentrici circuli ${ }^{76}$ lune et tantum distat a

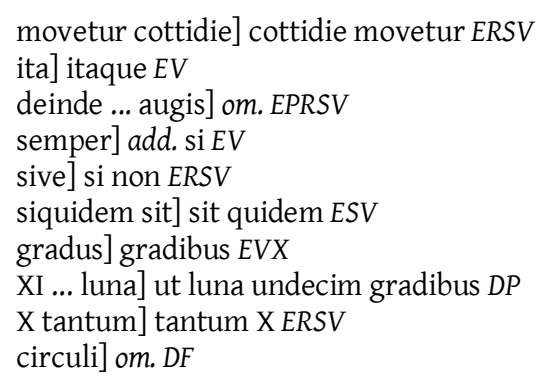


centro terre quantum centrum excentrici. Equatio puncti est distantia capitum duarum linearum in superiori circumferentia ${ }^{77}$ epicicli, quarum una a centro terre 180 et alia a centro excentrici circuli exeunt per centrum epicicli. Que equatio super portionem simplicem est addenda, si longitudo duplex est minor CLXXX gradibus, id est VI signis, vel minuenda ab eadem, ${ }^{78}$ si est maior. Que portio simplex post augmentum vel diminutionem equationis puncti 'portio coequata' nominatur.

Equatio diversitatis diametri circuli brevis est distantia capitum duarum

185 linearum in superiori circumferentia epicicli, quarum una exit a centro terre et alia a centro predicto, quod est inter terram et longitudinem propiorem excentrici, per centrum epicicli. ${ }^{79}$ Minuta proportionum sunt numeri proportionales quorum proportionalitate cum LX accipitur illud quod debet aggregari equationi portionis de equatione diversitatis diametri circuli brevis. Numeri vero ${ }^{80}$ proportionales

190 dicuntur LX partes per quas diviserunt totam medietatem circuli que est a longitudine longiori ${ }^{81}$ usque ad propiorem, ut quantum fuerint minuta proportionum de LX, id est quantum luna descendit ab auge vel ascenderet, tantam $^{82}$ partem acciperent de equatione diversitatis diametri circuli brevis ${ }^{83}$ et illud adderent super equationem portionis. Equatio vero portionis est distantia 195 capitum duarum linearum in circulo signorum exeuntium a centro terre, quarum una exit per centrum epicicli, alia vero per corpus lune in circumferentia epicicli transit. Que equatio portionis addita ${ }^{84}$ eidem equationi ${ }^{85}$ diversitatis diametri ${ }^{86}$ circuli brevis quantum sunt minuta proportionum de LX dicitur 'equatio portionis equata' ${ }^{87}$ Que equatio portionis equata debet aggregari ${ }^{88}$ medio cursui lune, si portio equata fuerit maior CLXXX gradibus, id est VI signis, vel minui, si minor.

Sed ut ea que diximus luce clariora constent, speram lune depingamus et circulos cum centris eorum manifestis indiciis determinemus. Sit circulus signorum $A B C D$ super centrum $\mathrm{E}$ descriptus, quod est centrum terre. Circulus vero excentricus lune LMNR circumscribatur super centrum O. Deinde posito pede 205 circini super centrum terre fiat brevis circulus secundum spatium centri excentrici $O$, ut centrum $O$ sit in circumferentia illius circuli. In opposita vero parte eiusdem circumferentie sit centrum $Q$, ad quod refertur diametrus epicicli, quod scilicet est

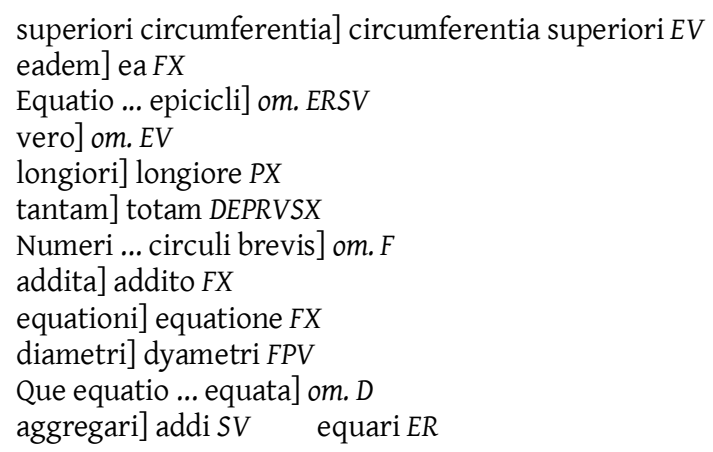


inter longitudinem propiorem excentrici circuli, que est $r$, et centrum terre, E. ${ }^{89}$ Item posito centro in circumferentia excentrici secundum quantitatem parvi 210 circuli cuius centrum est centrum terre epiciclus describatur et sit centrum illud L. ${ }^{90}$ Iste autem epiciclus fiat in quatuor partibus excentrici, ut semper centrum illud sit in ipsa ${ }^{91}$ circumferentia excentrici.

Rursus super centrum excentrici, quod est 0 , per summitatem epicicli describatur circulus et ostendit augem lune, quod est S. Similiter super idem 215 centrum, scilicet $\mathrm{O}$, describatur circulus per inferiorem partem epicicli et ostendit longitudinem propiorem excentrici, que est $r$. Rursum ${ }^{92}$ super centrum terre E per summitatem epicicli, quam denotat $\mathrm{S}$, describatur circulus qui est ${ }^{93}$ similis circulo signorum. Super idem quoque centrum per inferiorem partem epicicli, quam significat $r$, describatur circulus et iste ostendit ${ }^{94}$ inferiorem superficiem spere

220 lune, suppremus autem ostendit ${ }^{95}$ superficiem superiorem. Quod vero continetur inter superficiem superiorem et inferiorem est spissitudo circuli in qua corpus lune ${ }^{96}$ defertur.

Si quis igitur intente prescriptam figuram contempletur, ea que diximus procul dubio reperiet, id est quid portio, quid equatio portionis, quid etiam diversitas diametri circuli brevis, et quid equatio puncti et huiusmodi. ${ }^{97}$

\footnotetext{
E] om. DX

L] I FRV

ipsa] om. PV

Rursum] Rursus EFV

est] add. circulus $D X$

ostendit] ostendet $D P$

ostendit] ostendet DP

lune] planete ERSVX

Si quis ... huiusmodi] om. $D$
} 


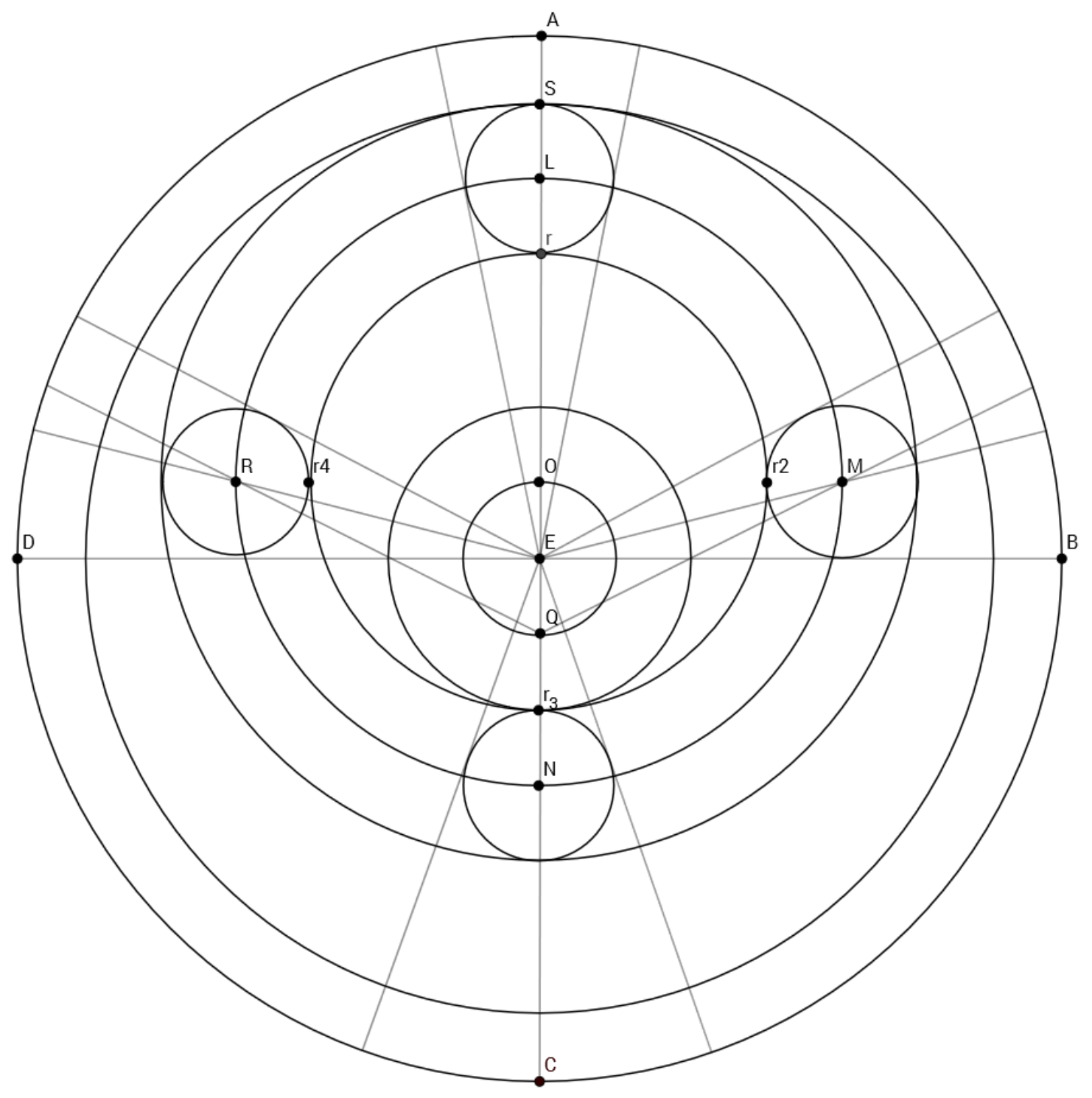

Fig. 2: Figura spere lune 
$<$ De motu quinque planetarum $>$

Post tractatum luminarium ${ }^{98}$ de quinque planetis erraticis consequenter tractabimus. Illud autem commune in primis assignandum quod omnes quinque 230 duos habent excentricos, unum in quo defertur centrum epicicli, qui etiam movetur ab occidente in orientem, ${ }^{99}$ alium vero ad quem refertur ${ }^{100}$ motus centri epicicli, qui etiam immobilis est positus in directo alterius et eiusdem quantitatis et secundum istum consideratur medius cursus planete. Unde ab Alfragano ${ }^{101}$ dicitur 'circulus equans motum'. Medius itaque cursus uniuscuiusque istorum quinque planetarum est quantum vadit centrum epicicli in excentrico circulo. 'Punctus' vero dicitur spatium quod est inter centrum epicicli et augem planete, quod dicitur "longitudo duplex ${ }^{102}$ in luna. Portio vero planete est spatium ${ }^{103}$ in circumferentia epicicli quod est inter corpus planete et summitatem linee que dirigitur a centro circuli excentrici equantis motum per centrum epicicli. Equatio 240 puncti est distantia capitum ${ }^{104}$ duarum linearum in circumferentia epicicli quarum una exit a centro terre et alia a centro circuli excentrici ${ }^{105}$ equantis motum per centrum epicicli. ${ }^{106}$ Equatio portionis eadem est que in luna. 'Longitudo longior' ${ }^{107}$ vocatur in hiis quinque quod 'equatio diversitatis diametri circuli brevis' in luna.

Hec quidem communia sunt omnibus quinque. Nunc autem proprias singulis

245 describamus figuras et in unaquaque figura quot sint motus cuiuslibet planete et quid unicuique planete sit proprium lucidis demonstremus exemplis. Et quoniam ${ }^{108}$ Mercurius discretam ab aliis habet speram et plures quam alii planete in sua spera volutationes, ${ }^{109}$ primo Mercurii speram depingamus, postmodum unam solam figuram pro aliis tribus [!] planetis subiciemus, quoniam in motibus et circulis conveniunt.

Mercurius itaque quatuor motus habet. Unus est quo corpus planete movetur in epiciclo, in superiori quidem parte ab occidente in orientem, in inferiori vero parte $\mathrm{ab}$ oriente in occidentem, econtrario motui ${ }^{110}$ lune. Unde in inferiori parte

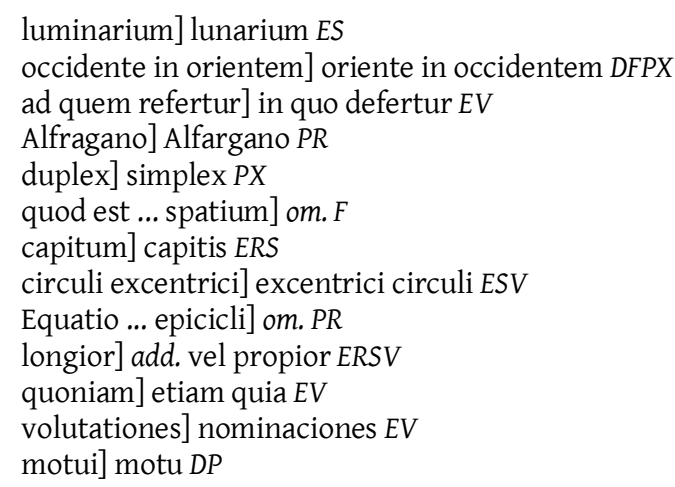


retrogradus est, superius vero directus, in quo convenit Mercurius cum aliis tribus 255 [!] planetis.

Alter ${ }^{111}$ motus Mercurii est motus centri epicicli in excentrico circulo ab occidente in orientem, et ille excentricus vocatur "circulus excentricus deferens centrum epicicli'.

Tertius motus Mercurii est motus centri illius excentrici ab oriente in occidentem in circumferentia parvi circuli, cuius centrum est extra centrum terre et vertit longitudinem longiorem excentrici secum versus occidentem et sic movetur excentricus deferens centrum epicicli versus occidentem.

Quartus motus Mercurii est similis motui ${ }^{112}$ stellarum fixarum, id est in centum annis uno gradu.

265 Sicut autem superius meminimus, habet Mercurius ${ }^{113}$ alium excentricum immobilem, qui dicitur 'equans motum', eo quod motus centri epicicli referatur ad illum excentricum, quoniam medius cursus attenditur in illo excentrico. Secundum istum etiam ${ }^{114}$ circulum consideratur augis Mercurii, quia in directo illius partis excentrici circuli equantis motum qui remotior est a centro terre est 270 augis ${ }^{115}$ Mercurii in circulo signorum.

Nunc ad evidentiam dictorum ${ }^{116}$ circulos Mercurii describamus et per litteras denotemus. Describatur igitur ${ }^{117}$ circulus signorum exterius ABCD super centrum $\mathrm{E}$, quem dividant duo diametri per medium in quatuor partes. Rursum ${ }^{118}$ in diametro terre superius super centrum $Q$ circumscribatur circulus excentricus

275 Mercurii deferens centrum epicicli, qui circulus mobilis est, scilicet LMNR. Item super centrum $O$, quod est inter centrum $\mathrm{E}$ et centrum $\mathrm{Q}$, in diametro videlicet terre, describatur alius circulus ${ }^{119}$ excentricus, ${ }^{120}$ quem circulum denotat o littera quasi corpus planete ubique in circumferentia depicta. Rursum secundum spatium utriusque centri, id est centri $Q$ et centri $O$, designetur ${ }^{121}$ parvus circulus cuius 280 centrum sit I. ${ }^{122}$ Centrum itaque $Q$ movetur ab oriente versus occidentem et movet secum suum circulum excentricum. Centrum vero 0 , quod est centrum circuli equantis motum, immobile est. Unde fit ut cum utrumque centrum sit in

111 Alter] add. vero DP

112 motui] add. spere $P X$

113 habet Mercurius] Mercurius habet DFP

114 istum etiam] etiam istum ESV

115 partis ... augis] om. ERSV

116 dictorum] predictorum EFRSV

117 igitur] om. EV

118 Rursum] Rursus DV

119 circulus] om. DEFRSV

120 excentricus] add. equans motum et immobilis eiusdem quantitatis cuius est et alius ecentricus $D$

121 designetur] denotetur ERSV

122 I] A DFPX 
circumferentia parvi circuli fiant quandoque unum centrum et duo illi ${ }^{123}$ excentrici sunt unus, cum scilicet centrum $Q$ moveatur versus occidentem et perveniat ad 285 centrum 0.

Item secundum quantitatem parvi circuli $^{124}$ in cuius circumferentia sunt predicta duo centra fiat epiciclus posito centro in circumferentia excentrici cuius centrum est $Q$ designeturque centrum epicicli per litteram L. Quod centrum simul cum epiciclo rotatur ${ }^{125} \mathrm{ab}$ occidente in orientem et numquam separatur illud centrum a circumferentia excentrici. Rursus super centrum $Q$ secundum spatium summitatis epicicli, quam notat F, describatur circulus. Similiter per inferiorem partem epicicli super idem centrum fiat circulus. Item super centrum terre E circumscribatur circulus ${ }^{126}$ per summitatem epicicli eandem ubi extrinsecus contingit summitatem epicicli, scilicet $F,{ }^{127}$ et hoc dicitur' ${ }^{128}$ 'superficies 295 superiorum'129 sive 'circulus similis circulo signorum'. Super idem ${ }^{130}$ centrum, scilicet $\mathrm{E}$, per longitudinem propiorem epicicli, quam significat $\mathrm{T},{ }^{131}$ describatur circulus qui est inferior superficies circuli Mercurii. Augis vero Mercurii in directo illius partis circuli equantis motum, que remotior est a terra in circulo signorum, determinatur, que est in Libra. Superiorem autem partem circuli excentrici 300 equantis motum, id est ubi plus elongatur a terra, designat littera $f$. Ceterum lineas plures, tam a centro terre, quam a centro excentrici circuli ${ }^{132}$ motum equantis, protraximus, ut diligens lector sine ${ }^{133}$ nostro labore inveniat quid portio, quid equatio puncti, quid equatio portionis et cetera que superius exposita sunt. ${ }^{134}$

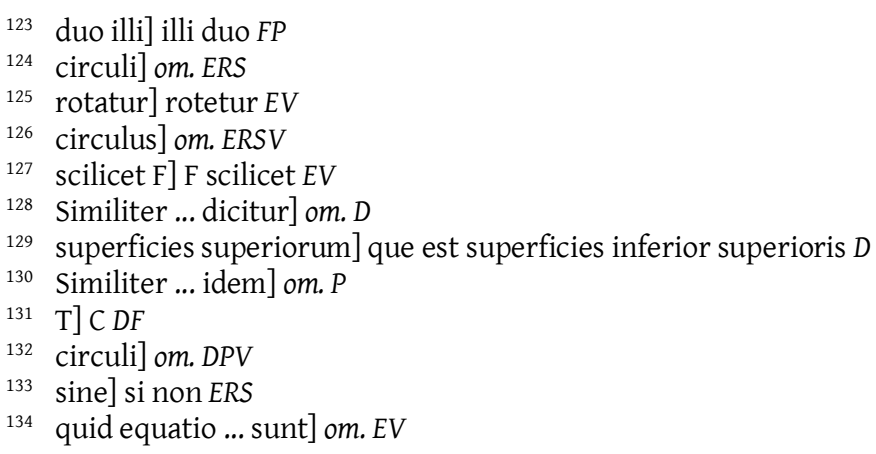




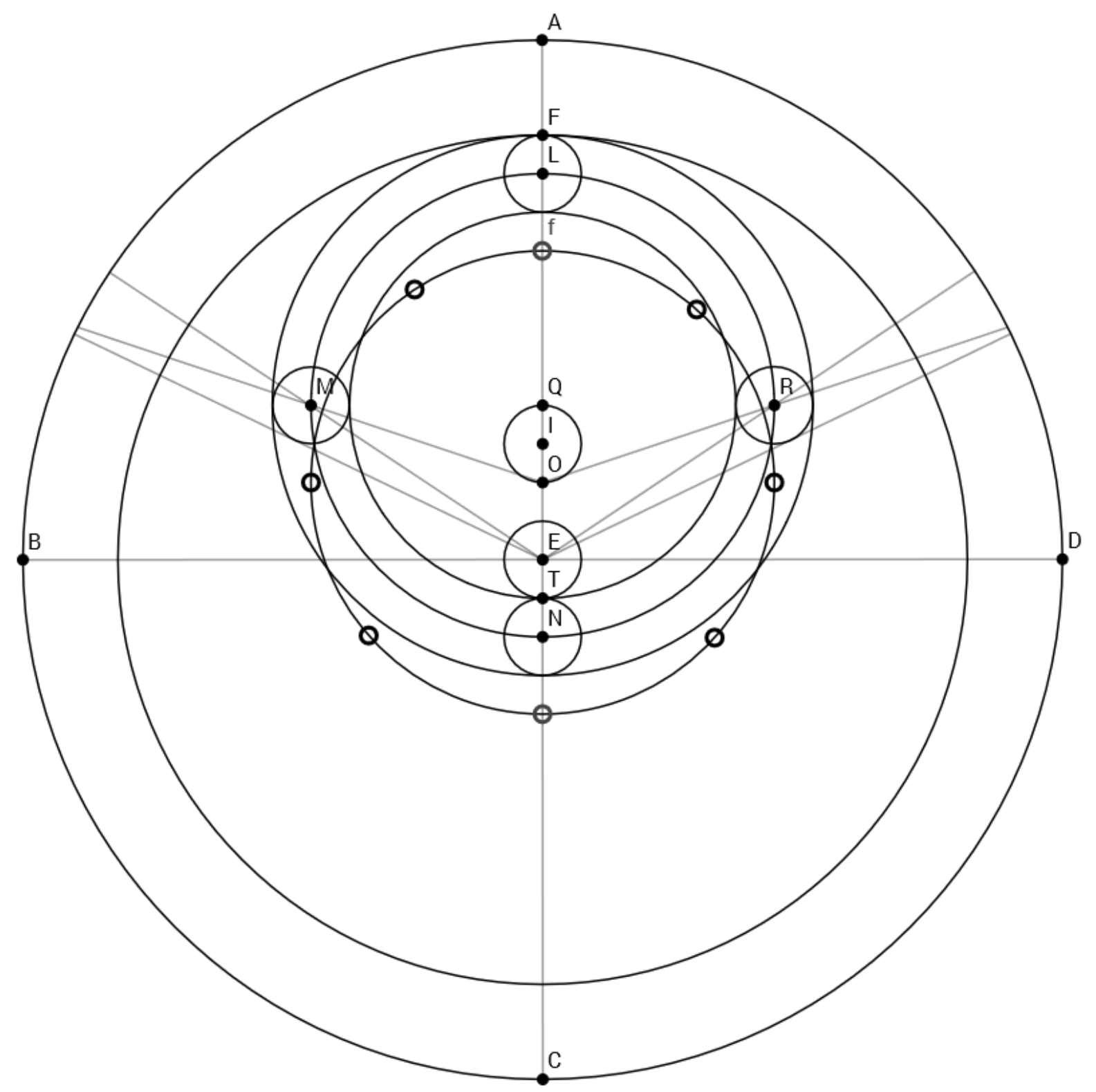

Fig. 3: Figura spere Mercurii 
305 Demum ad motus quatuor planetarum erraticorum veniamus, scilicet Saturni, ${ }^{135}$ Iovis, Martis et ${ }^{136}$ Veneris, qui in circulis motibusque non discrepant, nisi quod unus alio maiorem habet circulum, Saturnus videlicet ${ }^{137}$ quam Iupiter, Iupiter quam Mars, Mars quam Venus. Preterea auges eorum sunt diverse. Nam Saturnus augem habet in Sagittario, Iupiter in Virgine, Mars in Leone. Veneris autem ${ }^{138}$ augis

310 est sicut et ${ }^{139}$ solis in signo Geminorum. Ceterum in omnibus predicti quatuor planete conveniunt. Proinde unam ex illis speram designabimus et in ea secundum circulorum varietatem diversitates motuum distinguemus.

Sunt itaque unicuique istorum tres motus: unus quo corpus planete movetur in epiciclo in superiori quidem parte epicicli ${ }^{140}$ ab occidente versus ${ }^{141}$ orientem, in 315 inferiori vero ab oriente in occidentem, sicut et ${ }^{142}$ Mercurius. Unde in summitatibus suorum epiciclorum ${ }^{143}$ directi sunt, in inferiori vero ${ }^{144}$ parte retrogradi, econtrario lune.

Alter motus est motus centri epicicli in circumferentia excentrici ab occidente quidem versus orientem semper.

320 Tertius motus est equalis motui stellarum fixarum quo in omnibus centum annis uno gradu movetur.

Et notandum ${ }^{145}$ quod unusquisque istorum quatuor duos habet excentricos, sicut et Mercurius. Sed in Mercurio excentricus circulus deferens centrum epicicli movetur ab oriente in occidentem. Circulus autem excentricus equans motum 325 immobilis est. In istis vero quatuor planetis uterque circulus excentricus immobilis perseverat et eorum similiter centra. Item centrum excentrici circuli deferentis ${ }^{146}$ centrum epicicli est inter centrum circuli excentrici equantis motum et inter centrum terre spere, contrario ei quod videmus in Mercurio. Nam quandoque centra $^{147}$ duorum excentricorum circulorum Mercurii sunt unum, quandoque 330 autem centrum excentrici motum equantis est inter centrum excentrici circuli deferentis centrum epicicli et inter centrum terre.

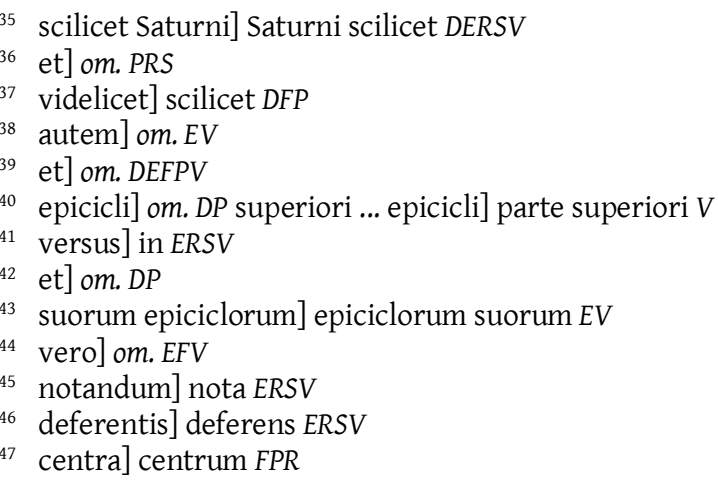


Et quoniam supra exposuimus quid sit medius ${ }^{148}$ cursus cuiuslibet $^{149}$ istorum, quid etiam punctus et portio, sed ${ }^{150}$ et quid equatio puncti quidque ${ }^{151}$ equatio ${ }^{152}$ porcionis, speram unam eorum depingamus et circulum quemque per litteras 335 denotemus. ${ }^{153}$ Super centrum igitur E, quod est centrum terre, sive circuli signorum, constituatur circulus signorum $A B C D$. Rursus in diametro exeunte a centro terre sit centrum $Q$ super quod describatur circulus excentricus equans motum, quem designat littera o ubique in circumferentia eiusdem excentrici, quasi corpus planete depicta, ut superior o ostendat augem, id est longitudinem 340 longiorem, ${ }^{154}$ inferior vero o demonstret oppositum augis, id est longitudinem propiorem.

Item inter ${ }^{155}$ centrum $Q$ et centrum $E$ in medio sit centrum I equalitater distans $\mathrm{ab}$ utroque, super quod constituatur circulus excentricus deferens centrum epicicli. Eiusdem ${ }^{156}$ fiat quantitatis cuius est et alius excentricus equans motum et

345 sit LMNR. Rursum secundum quantitatem qua ${ }^{157}$ distat centrum $\mathrm{Q}$ a centro I fiat epiciclus cuius centrum L sit in circumferentia excentrici ${ }^{158}$ LMNR, semper ita ut summitas epicicli tangat longitudinem longiorem excentrici circuli motum equantis quam notat $o$. Fiant quoque alii tres epicicli in circumferentia excentrici, duo quidem ex utraque parte, tertius autem ${ }^{159}$ in parte inferiori ut inferior pars epicicli ${ }^{160}$ contingat longitudinem propiorem excentrici motum equantis.

Item super centrum I per summitatem epicicli quam designat o describatur circulus. Similiter super idem centrum per inferiorem partem epicicli designetur circulus. Rursum super centrum terre, quod est centrum ${ }^{161} \mathrm{E}$, per summitatem epicicli quam ${ }^{162}$ notat $o$ describatur circulus ${ }^{163}$ qui dicitur 'superior superficies 355 circuli'. Similiter super idem centrum per longitudinem propiorem quam similiter denotat o designetur circulus qui dicitur 'inferior superficies'. Et iam perfecta est spera predictorum ${ }^{164}$ quatuor planetarum erraticorum, nisi quod lineas plures tam

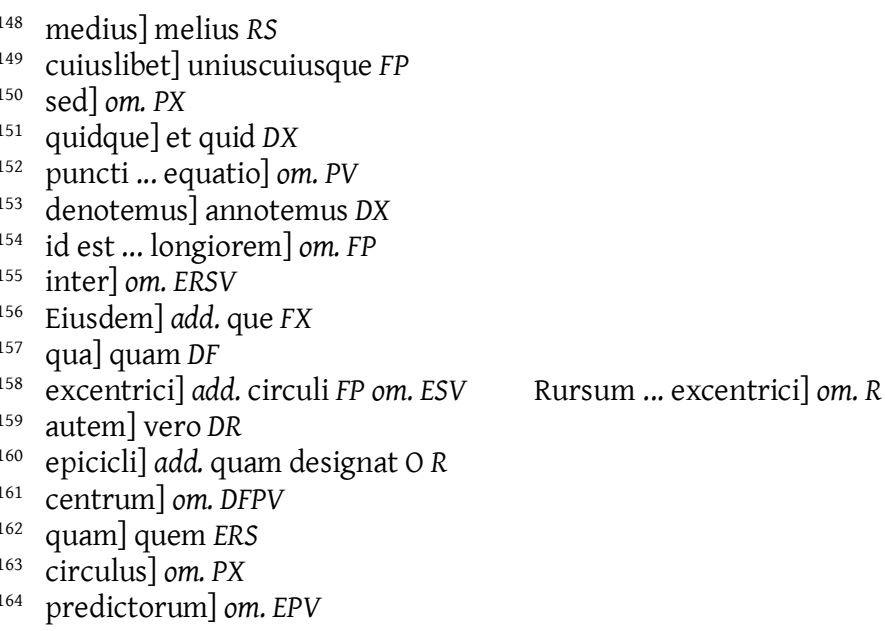


a centro terre quam a centro circuli excentrici equantis motum protraximus, ut in ea portionem et punctum, equationem quoque puncti et equationem portionis diligens lector perspicaciter investiget.

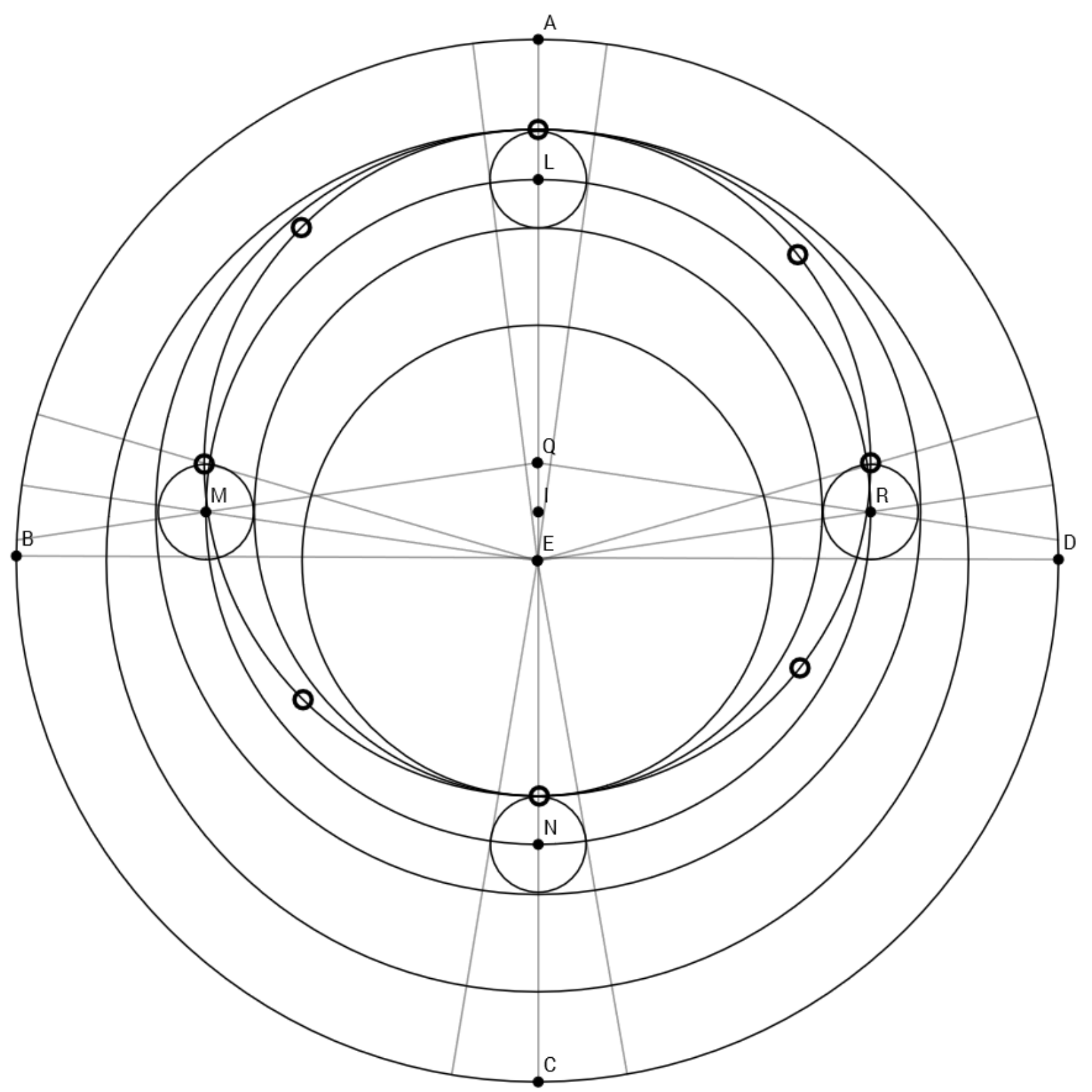

Fig. 4: Figura sperarum quatuor planetarum 
$<$ Summarie de motibus planetarum $>$

365 Ut igitur ${ }^{165}$ breviter omnia concludam: sol duos habet motus ab occidente in orientem, unum ${ }^{166}$ quo movetur in suo excentrico circulo omni die ${ }^{167}$ LIX minutis et VIII secundis, alium quo ${ }^{168}$ in omnibus centum annis cum spera octava movetur uno gradu. Spera vero solis tota per se immobilis est, ${ }^{169}$ nisi quantum ex nona spera omni die et nocte movetur.

370 Luna vero quinque motus habet: unum quo corpus lune in epiciclo movetur ${ }^{170}$ ab oriente in occidentem omni die XIII gradibus et IIII minutis de gradibus circuli brevis. Alium quo centrum epicicli simul cum epiciclo rotatur ab occidente versus orientem XXIIII gradibus et XXIII minutis de circulo excentrico deferente centrum. Tertium autem quo centrum excentrici deferentis centrum epicicli movetur ab 375 oriente in occidentem XI gradibus et IX minutis vertens secum longitudinem longiorem excentrici, id est augem lune. Quartum vero quo caput et cauda, id est abscisiones quas faciunt circulus lune et solis, moventur ab oriente in occidentem impetuositate excentrici omni die duobus minutis, ${ }^{171}$ que duo minuta cum predictis $\mathrm{XI}$ gradibus et IX minutis que centrum excentrici peragunt ${ }^{172}$ minuenda sunt de 380 XXIIII gradibus et XXIII minutis centri epicicli, et remanebit medius cursus lune in circulo simili circulo signorum. Quintus motus lune equalis est ${ }^{173}$ motui spere stellarum fixarum.

Mercurius equidem quatuor habet motus: unum quo corpus planete movetur in suo $^{174}$ epiciclo, in superiori quidem parte ab occidente in orientem, in inferiori 385 econverso omni die tribus gradibus et 6 minutis. Alium quo centrum epicicli in circumferencia excentrici rotatur ab occidente in orientem ${ }^{175}$ uno gradu et LVIII minutis. ${ }^{176}$ Tertium autem quo centrum excentrici deferentis centrum epicicli movetur ab oriente in occidentem LIX minutis et VIII ${ }^{177}$ secundis. Quartum vero communem habet cum spera stellarum fixarum.

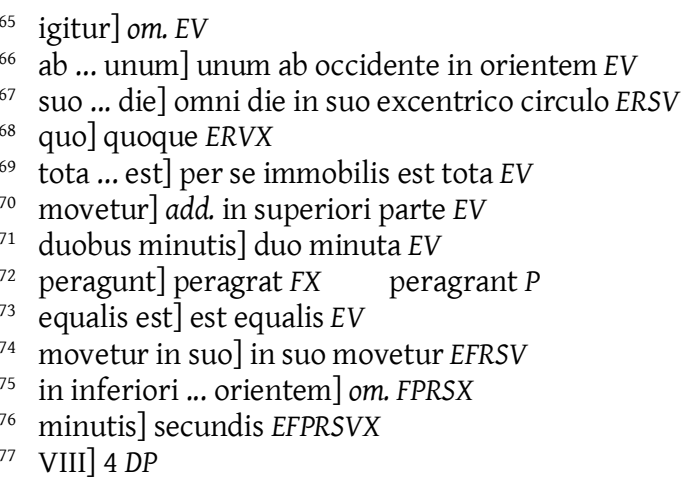


Reliqui quatuor planete, id est ${ }^{178}$ Saturnus, Iupiter, Mars, Venus, tres unusquisque motus habet: ${ }^{179}$ unum quo movetur planeta in epiciclo, alium quo centrum epicicli, tertium vero communem habet cum stellis fixis.

\section{$<$ Auges planetarum et eorum geuzahar $>$}

Preterea auges planetarum non sunt omittende et eorum geuzahar. ${ }^{180}$ Augis enim solis et Veneris est in Geminis, augis vero lune movetur, ita videlicet ut cum coniuncta ${ }^{181}$ fuerit luna soli et opposita sit in auge, Saturni in Sagittario, Iovis in Virgine, Martis in Leone, Mercurii in Libra.

400 Excentricus autem circulus solis non declinat usquequam a circulo signorum, unde non facit in eo aliquam abscisionem ideoque caret capite et cauda. Circulus vero lune declinat a zodiaco versus septemtrionem et meridiem, unde facit abscisionem in duobus locis oppositis qui vocantur 'caput' et 'cauda'. Sed movetur omni die, ut predictum est, duobus minutis. Geuzahar ${ }^{182}$ autem aliorum 405 planetarum immobilia sunt. Habent autem se sic: Saturni quidem est in Cancro et Iovis geuzahar ${ }^{183}$ in Leone,${ }^{184}$ Martis autem in Tauro, Veneris in Piscibus, ${ }^{185}$ Mercurii in Capricorno. ${ }^{186}$

\begin{tabular}{|c|c|c|c|}
\hline Geuzahar & signa & gradus & minuta \\
\hline Saturni & III & $\mathrm{X}$ & $\mathrm{XXX}^{187}$ \\
\hline Iovis & IIII & 0 & I \\
\hline Martis & I & I & LI \\
\hline Veneris & XI $^{188}$ & XVII & L \\
\hline Mercurii & VIIII $^{189}$ & XVII & III \\
\hline
\end{tabular}

178 id est] scilicet DEV

179 motus habet] habet motus FV

180 geuzahar] genzear $D$ genzaar $X$

181 coniuncta] iuncta DP

182 Geuzahar] Genzear D

183 geuzahar] genzaar $E$

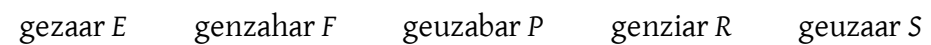

84 est ... Leone] et Iovis genzear est in Cancro $D$ quidem genzahar in Leone

in Leone et Iovis geuzahar est in Cancro $P \quad$ et Iovis genzaar est in Cancro $X$

185 Piscibus] Capricorno ESV

186 Capricorno] Sagittario ESV

187 XXX] XXXI ESV

$188 \mathrm{XI}] 9 \mathrm{EV} \quad$ IX $S$

189 VIIII] 8 EFV VIII $S$ 
410 Sunt ergo geuzahar ${ }^{190}$ planetarum ${ }^{191}$ ita, que dicuntur 'capita', 'caude' autem in oppositis. In capite vero et cauda est omnis planeta in media linea zodiaci, sed a capite septemtrionem petit, ${ }^{192}$ a cauda meridiem. Unde cum fuerit in medio a capite in caudam est in maxima latitudine sua septemtrionali, cum vero a cauda in caput erit in maxima meridionali. Distinguantur ergo ${ }^{193}$ sic: sit caput A, latitudo

415 septemtrionalis $B$, cauda C, latitudo meridionalis ${ }^{194}$ D. Dicitur igitur planeta 'ascendens in septemtrionem' ab A in B, 'descendens $\mathrm{a}^{195}$ septemtrione ${ }^{196} \mathrm{a}^{197} \mathrm{~B}$ in $C$, 'ascendens in meridiem' $\mathrm{a}^{198} \mathrm{C}$ in D, 'descendens a meridie' $\mathrm{a}^{199} \mathrm{D}$ in A. Secundum hoc igitur potest discerni quis cui in latitudine appropinquaverit. Cognita enim eius latitudine [!] per tabulam facile cognosci potest ${ }^{200}$ utrum sit ascendens an 420 descendens, et utrum in septemtrionem vel meridiem, per ea que hic dicta sunt, et sic quis cui appropinquaverit ${ }^{201} \mathrm{vel} \mathrm{ab}$ eo separatus fuerit. ${ }^{202}$

\footnotetext{
190 geuzahar]genzaar $E S$ genzahar $F$ genziar $R$

191 planetarum] om. EV

192 septemtrionem petit] petit septemtrionem $E V$

193 ergo] igitur FR

194 latitudo meridionalis] meridionalis latitudo ERV

195 a] in ERSV

196 septemtrione] in septemtrionem ERS

197 a] ab ERS

198 a] ab ESV

199 a] ab ESV

200 cognosci potest] potest cognosci FV

201 Cognita ... appropinquaverit] om. $P$

202 Sunt ergo ... fuerit] om. DX et sic ... fuerit] om. F
} 


\section{Bibliography \\ Manuscripts}

Berlin, Staatsbibliothek, lat. fol. 307

Bernkastel-Kues, Cusanusstiftsbibliothek (St.-Nikolaus-Hospital), 212

Brussels, Bibliothèque Royale, 1022-47

Cambrai, Bibliothèque (Médiathèque) municipale, 930

Cambridge, Fitzwilliam Museum, McClean 165

Cambridge, University Library, Kk.1.1

Chartres, Bibliothèque municipale, 214

Erfurt, Universitäts- und Forschungsbibliothek, CA $2^{\circ} 394$

Erfurt, Universitäts- und Forschungsbibliothek, CA $4^{\circ} 357$

London, British Library, Arundel 377

London, British Library, Cotton App. VI

Lüneburg, Ratsbücherei, Miscell. D $2^{\circ} 13$

Madrid, Biblioteca nacional de España, 10016

Madrid, Biblioteca nacional de España, 10059

Munich, Bayerische Staatsbibliothek, Clm 10268

Oxford, Bodleian Library, Digby 47

Oxford, Bodleian Library, Digby 97

Oxford, Bodleian Library, Rawlinson D.893

Oxford, Bodleian Library, Savile 21

Oxford, Bodleian Library, Savile 22

Oxford, Bodleian Library, Selden supra 26

Oxford, Bodleian Library, Selden supra 76

Oxford, Merton College, 259

Paris, Bibliothèque nationale de France, lat. 7298

Paris, Bibliothèque nationale de France, lat. 16208

Parma, Biblioteca Palatina, 718-720

Seville, Biblioteca Capitular Colombina, 5-1-25

Vatican City, Biblioteca Apostolica Vaticana, lat. 3133

Vatican City, Biblioteca Apostolica Vaticana, Pal. lat. 1414

Vienna, Österreichische Nationalbibliothek, 5311

\section{Books \& Articles}

Abū Ma shar, On Historical Astrology: The Book of Religions and Dynasties (On the Great Conjunctions), edited by Keiji Yamamoto and Charles Burnett, 2 vols, (Islamic Philosophy, Theology, and Science, 33-34), Leiden: Brill, 2000. 
Aiton, E. J., 'Peurbach's Theoricae Novae Planetarum: A Translation with Commentary', Osiris, $2^{\text {nd }}$ ser., 3 (1987), pp. 4-43.

Al-Battānī, De motu stellarum (trans. Plato Tiburtinus) = Continentur in hoc libro: Rudimenta astronomica Alfragrani. Item Albategnius astronomus peritissimus de motu stellarum, Nuremberg: Petreius, 1537.

Alonso Alonso, Manuel, 'Juan Sevillano, sus obras proprias y sus traducciones', AlAndalus 18 (1953), pp. 17-49.

Avi-Yonah, Reuven S. 'Ptolemy vs al-Bitruji: A Study of Scientific Decision-Making in the Middle Ages', Archives internationales d'histoire des sciences 35 (1985), pp. 124147.

Baur, Ludwig, Die philosophischen Werke des Robert Grosseteste, Bischofs von Lincoln, (Beiträge zur Geschichte der Philosophie des Mittelalters: Texte und Untersuchungen, 9), Münster: Aschendorff, 1912.

Benjamin, Francis S., Jr, and G. J. Toomer (eds), Campanus of Novara and Medieval Planetary Theory: 'Theorica planetarum', Madison: University of Wisconsin Press, 1971.

Burnett, Charles, 'Algorismi vel helcep decentior est diligentia: The Arithmetic of Adelard of Bath and His Circle', in Menso Folkerts (ed.) Mathematische Probleme im Mittelalter: Der lateinische und arabische Sprachbereich, Wiesbaden: Harrassowitz, 1996, pp. 221-331.

- 'John of Seville and John of Spain: A Mise au point', Bulletin de philosophie médiévale 44 (2002), pp. 59-78. Reprinted as chapter VI in Id., Arabic into Latin in the Middle Ages: The Translators and Their Intellectual and Social Context, (Variorum Collected Studies Series, 939), Farnham: Ashgate, 2009.

Byrne, James Steven, 'The Stars, the Moon, and the Shadowed Earth: Viennese Astronomy in the Fifteenth Century', PhD Diss., Princeton University, 2007.

- 'The Mean Distances of the Sun and Commentaries on the Theorica Planetarum', Journal for the History of Astronomy 42 (2011), pp. 205-221.

Campani, Romeo (ed.), Alfragano (al-Farghānī): Il 'Libro dell'aggregazione delle stelle' (Dante, Conv., II, vi-134) secondo il Codice Mediceo-Laurenziano, Pl. 29, cod. 9 contemporaneo a Dante, Città di Castello: Lapi, 1910.

Carmody, Francis J. (ed.), Al Farghani Differentie, Berkeley: University of California Press, 1943.

- Theorica Planetarum Gerardi, Berkeley, CA: n.a., 1942. 
Chabás, José, and Bernard R. Goldstein, A Survey of European Astronomical Tables in the Late Middle Ages, (Time, Astronomy, and Calendars: Texts and Studies, 2), Leiden: Brill, 2012.

Dickey, Bruce George, 'Adelard of Bath: An Examination Based on heretofore Unexamined Manuscripts', PhD diss., University of Toronto, 1982.

Duhem, Pierre, Un fragment inédit de l'Opus tertium de Roger Bacon: précédé d'une étude sur ce fragment, Quaracchi: Ex Typographia Collegii S. Bonaventurae, 1909.

- Le système du monde: histoire des doctrines cosmologiques de Platon à Copernic, vol. III, Paris: Hermann, 1915.

Edwards, Glenn M., 'The Two Redactions of Michael Scot's Liber introductorius', Traditio 41 (1985), pp. 329-340.

Federici Vescovini, Graziella, 'Autour de la Theorica planetarum Gerardi', in Donatella Nebbiai-Dalla-Guarda and Jean-François Gesnet (eds), Du copiste au collectionneur: mélanges d'histoire des textes et des bibliothèques en l'honneur d'André Vernet, Turnhout: Brepols, 1998, pp. 169-174.

- 'Michel Scot et la Theorica Planetarum Gerardi', Early Science and Medicine 1 (1996), pp. 272-282.

Grant, Edward (ed.), A Source Book in Medieval Science, Cambridge, MA: Harvard University Press, 1974.

Grant, Edward, 'Celestial Motions in the Late Middle Ages', Early Science and Medicine 2 (1997), pp. 129-148.

- Planets, Stars, and Orbs: The Medieval Cosmos, 1200-1687, Cambridge: Cambridge University Press, 1994.

Grupe, Dirk, 'Stephen of Pisa's Theory of the Oscillating Deferents of the Inner Planets (1h. 12 ${ }^{\text {th }}$ C.)', Archive for History of Exact Sciences 71 (2017), pp. 379-407.

Hartner, Willy, 'The Mercury Horoscope of Marcantonio Michiel of Venice: A Study in the History of Renaissance Astrology and Astronomy', Vistas in Astronomy 1 (1955), pp. 84-138.

Hasse, Dag Nikolaus, 'Averroes' Critique of Ptolemy and Its Reception by John of Jandun and Agostino Nifo', in Paul J. J. M. Bakker (ed.), Averroes' Natural Philosophy and Its Reception in the Latin West, Leuven: Leuven University Press, 2015, pp. 69-88.

- 'Stylistic Evidence for Identifying John of Seville with the Translator of Some Twelfth-Century Astrological and Astronomical Texts from Arabic into Latin on the Iberian Peninsula', in Charles Burnett and Pedro Mantas-España (eds), 'Ex 
Oriente Lux': Translating Words, Scripts and Styles in Medieval Mediterranean Society, (Serie Arabica Veritas, 2), Córdoba: UCOPress, 2016, pp. 19-43.

Hugonnard-Roche, Henri, 'Contribution arabe à la cosmologie occidentale latine', in Cieli e terre nei secoli XI-XII: orizzonti, percezioni, rapporti; Atti della tredicesima Settimana internazionale di studio Mendola, 22-26 agosto 1995, (Miscellanea del Centro di studi medioevali, 15), Milan: Vita e pensiero, 1998, pp. 89-109.

- 'Problèmes méthodologiques dans l'astronomie au début du XIVe siècle', in Gad Freudenthal (ed.), Studies on Gersonides: A Fourteenth-Century Jewish PhilosopherScientist, (Collection de travaux de l'Académie internationale d'histoire des sciences, 36), Leiden: Brill, 1992, pp. 55-70.

Hunt, R. W. and A. G. Watson, Bodleian Library Quarto Catalogues, vol. IX.2, Notes on Macray's Descriptions of the Manuscripts, Oxford: Bodleian Library, 1999.

Juste, David, Catalogus codicum astrologorum latinorum, vol. II, Les manuscrits astrologiques latins conservés à la bibliothèque nationale de France à Paris, (Documents, études et répertoires, 84), Paris: CNRS, 2015.

Kunitzsch, Paul, Glossar der arabischen Fachausdrücke in der mittelalterlichen europäischen Astrolabliteratur, Göttingen: Vandenhoeck \& Ruprecht, 1982.

Langermann, Y. Tzvi, 'A Note on the Use of the Term Orbis (Falak) in Ibn alHaytham's Maquālah fi hay'at al-'ālam', Archives internationales d'histoire des sciences 32 (1982), pp. 112-113.

Langermann, Y. Tzvi (ed. and trans), Ibn al-Haytham's on the Configuration of the World, New York: Garland Publishing, 1990. Reprint, London: Routledge, 2016.

Lerner, Michel-Pierre, Le monde des sphères, vol. I, Genèse et triomphe d'une représentation cosmique, Paris: Les Belles Lettres, 1996.

Lohr, Alfred, Opera de computo saeculi duodecimi, (Corpus Christianorum Continuatio Mediaevalis, 272), Turnhout: Brepols, 2015.

Macray, William D. Catalogi Codicum Manuscriptorum Bibliothecae Bodleianae. Vol. V.4. Oxford: Clarendon Press, 1898.

- Catalogi Codicum Manuscriptorum Bibliothecae Bodleianae, vol. IX, Oxford: Clarendon Press, 1883.

Madan, Falconer, and H. H. Craster, A Summary Catalogue of Western Manuscripts in the Bodleian Library at Oxford, vol. II.1, Oxford: Clarendon Press, 1922.

Malpangotto, Michela, 'Les premiers manuscrits des Theoricae novae planetarum de Georg Peurbach: présentation, description, évolution d'un ouvrage', Revue d'histoire des sciences 65 (2012), pp. 339-380. 
- 'The Original Motivation for Copernicus's Research: Albert Brudzewo's Commentariolum super Theoricas novas Georgi Purbachii', Archive for History of Exact Sciences 70 (2016), pp. 361-411.

Mancha, José Luis, 'La version alfonsi del Fī hay'at al-'ālam (De configuratione mundi) de Ibn al-Haytham (Oxford, Canon misc. 45, ff. 1r-56r)', in Mercè Comes, Honorino Mielgo, and Julio Samsó (eds), 'Ochava espera' y 'astrofísica': textos y estudios sobre las fuentes árabes de la astronomía de Alfonso X, Barcelona: Instituto 'Millás Vallicrosa' de Historia de la Ciencia Árabe, 1990, pp. 133-207.

Mercier, Raymond, 'Astronomical Tables in the Twelfth Century', in Charles Burnett (ed.), Adelard of Bath: An English Scientist and Arabist of the Early Twelfth Century, (Warburg Institute Surveys and Texts, 14), London: The Warburg Institute, 1987, pp. 87-118. Reprinted as chapter VII in Mercier, Studies on the Transmission of Medieval Mathematical Astronomy, (Variorum Collected Studies Series, 787), Aldershot: Ashgate, 2004.

- 'The Lost Zij of al-Ṣūî in the Twelfth-Century Tables for London and Pisa', Chapter VIII in Mercier, Studies on the Transmission of Medieval Mathematical Astronomy, (Variorum Collected Studies Series, 787), Aldershot: Ashgate, 2004.

Millás Vallicrosa, José M. a, 'Una obra astronómica desconocida de Johannes Avendaut Hispanus', Osiris 1 (1936), pp. 451-475. Reprinted as chapter X in Id., Estudios sobre historia de la ciencia española, Barcelona: CSIC, 1949.

- Las traducciones orientales en los manuscritos de la Biblioteca Catedral de Toledo, Madrid: CSIC, 1942.

- El libro de los fundamentos de las Tablas astronómicas de R. Abraham Ibn Ezra, (Instituto Arias Montano, Ser. D, 2), Madrid: CSIC, 1947.

Mimura, Taro, 'A Glimpse of Non-Ptolemaic Astronomy in Early Hay'a WorkPlanetary Models in ps. Mashā'allāh's Liber de orbe', Suhayl 14 (2015), pp. 89-114.

- 'The Arabic Original of (ps.) Māshā'allāh's Liber de orbe: Its Date and Authorship', British Journal for the History of Science 48 (2015), pp. 321-352.

Morgan, Nigel, and Stella Panayotova, A Catalogue of Western Book Illumination in the Fitzwilliam Museum and the Cambridge Colleges, pt. I, vol. II, London: Harvey Miller Publishers, 2009.

Müller, Kathrin, Visuelle Weltaneignung: Astronomische und kosmologische Diagramme in Handschriften des Mittelalters, (Historische Semantik, 11), Göttingen: Vandenhoeck \& Ruprecht, 2008.

North, John D., Richard of Wallingford: An Edition of His Writings, with Introductions, English Translation and Commentary, 3 vols, Oxford: Clarendon Press, 1976. 
- 'The Longitudes of Winchester', Cahiers de l'Institut du Moyen-Âge Grec et Latin 73 (2002), pp. 13-20.

Nothaft, C. Philipp E., 'Criticism of Trepidation Models and Advocacy of Uniform Precession in Medieval Latin Astronomy', Archives for History of Exact Sciences 71 (2017), pp. 211-241.

- Walcher of Malvern: 'De lunationibus' and 'De Dracone'; Study, Edition, Translation, and Commentary, (De Diversis Artibus, 101), Turnhout: Brepols, 2017.

Obrist, Barbara, 'William of Conches, Māshā'allāh, and Twelfth-Century Cosmology', Archives d'histoire doctrinale et littéraire du Moyen Âge 76 (2009), pp. 2987.

Pantin, Isabelle, 'The First Phases of the Theoricae Planetarum Printed Tradition (1474-1535): The Evolution of a Genre Observed through Its Images', Journal for the History of Astronomy 43 (2012), pp. 3-26.

Pedersen, Fritz S., 'Astronomical Tables for Pisa in Ms. København K.B., GkS 277, Fol.', Renaessanceforum 3 (2007), pp. 1-16.

- 'A Twelfth-Century Planetary Theorica in the Manner of the London Tables', Cahiers de l'Institut du Moyen-Âge Grec et Latin 60 (1990), pp. 199-318.

- The Toledan Tables: A Review of the Manuscripts and the Textual Versions with an Edition, 4 vols, (Det Kongelige Danske Videnskabernes Selskab, historisk-filosofiske Skrifter, 24), Copenhagen: Reitzel, 2002.

Pedersen, Olaf, 'The Theorica Planetarum and Its Progeny', in Graziella Federici Vescovini and Francesco Barocelli (eds), Filosofia, scienza e astrologia nel Trecento europeo: Biagio Pelacani Parmense, (Percorsi della scienza: storia, testi, problemi, 2), Padua: Il Poligrafo, 1992, pp. 53-78.

- 'The Decline and Fall of the Theorica Planetarum: Renaissance Astronomy and the Art of Printing', in Erna Hilfstein, Paweł Czartoryski and Frank D. Grande (eds), Science and History: Studies in Honor of Edward Rosen [= Studia Copernicana, 16], Wrocław: Wydawnictwo Polskiej Akademij Nauk, 1978, pp. 157-185.

- 'The Origins of the Theorica Planetarum', Journal for the History of Astronomy 12 (1981), pp. 113-123.

- 'The Problem of Walter Brytte and Merton Astronomy', Archives internationales d'histoire des sciences 36 (1986), pp. 227-248.

- 'The Theorica planetarum-Literature of the Middle Ages', Classica et Mediaevalia 23 (1962), pp. 225-232. 
Perry, Ben Edwin, Secundus the Silent Philosopher, (American Philological Association, Philological Monographs, 22), Ithaca, NY: American Philological Association, 1964.

Poulle, Emmanuel, 'Le vocabulaire de l'astronomie planétaire du XII ${ }^{\mathrm{e}}$ au XIV siècle', in Convegno internazionale: La diffusione delle scienze islamiche nel medio evo europo (Roma, 2-4 ottobre 1984), Rome: Accademia nazionale dei Lincei, 1987, pp. 193212.

Ragep, Sally P., 'Fifteenth-Century Astronomy in the Islamic World', in Rivka Feldhay and F. Jamil Ragep (eds), Before Copernicus: The Cultures and Contexts of Scientific Learning in the Fifteenth Century, Montreal \& Kingston: McGill-Queen's University Press, 2017, pp. 143-161.

Rashed, Roshdi, 'The Configuration of the Universe: A Book by al-Hasan ibn alHaytham?', Revue d'histoire des sciences 60 (2007), pp. 47-63.

Raymond of Marseilles, Opera omnia, vol. I, Traité de l'astrolabe, Liber cursuum planetarum, edited by Marie-Thérèse d'Alverny, Charles Burnett and Emmanuel Poulle, (Sources d'Histoire Médiévale, 40), Paris: CNRS, 2009.

Samsó, Julio, 'Dixit Abraham Iudeus: algunas observaciones sobre los textos astronómicos latinos de Abraham ibn 'Ezra', Iberia Judaica 4 (2012), pp. 171-200.

- 'El procés de la transmissió científica al nord-est de la península Ibèrica al segle XII: els textos llatins', in Joan Vernet and Ramon Parés (eds), La ciència en la història dels Països Catalans, vol. I, Dels àrabs al Renaixement, Valencia: Institut d'Estudis Catalans, 2004, pp. 269-296.

Schum, Wilhelm, Beschreibendes Verzeichnis der amplonianischen HandschriftenSammlung zu Erfurt, Berlin: Weidmann, 1887.

Sela, Shlomo, 'Algunos puntos de contacto entre el Libro de las tablas astronómicas en su versión latina y las obras literarias hebreas de Abraham Ibn Ezra', Miscelánea de Estudios Árabes y Hebraicos, Sección de Hebreo, 46 (1997), pp. 37-56.

- 'Contactos científicos entre judíos y cristianos en el siglo XII: el caso del Libro de las Tablas Astronómicas de Abraham Ibn Ezra en su versión latina y hebrea', Miscelánea de Estudios Árabes y Hebraicos, Sección de Hebreo, 45 (1996), pp. 185-222.

Shank, Michael H., 'Rings in a Fluid Heaven: The Equatorium-Driven Physical Astronomy of Guido de Marchia (fl. 1291-1310)', Centaurus 45 (2003), pp. 175-203.

Smithuis, Renate, 'Science in Normandy and England under the Angevins: The Creation of Abraham Ibn Ezra's Latin Works on Astronomy and Astrology', in Giulio Busi (ed.), Hebrew to Latin, Latin to Hebrew: The Mirroring of Two Cultures in the Age of 
Humanism; Colloquium Held at the Warburg Institute, London, October 18-19, 2004, (Berlin Studies in Judaism, 1), Turin: Aragno, 2006, pp. 23-60.

Steele, Robert (ed.), Opera hactenus inedita Rogeri Baconi, vol. IV, Liber secundus communium naturalium fratris Rogeri: De celestibus, Oxford: Clarendon Press, 1913.

Suter, Heinrich (ed.), Die astronomischen Tafeln des Muhammed ibn Mūsā al-Khwārizmī in der Bearbeitung des Maslama ibn Ahmed al-Madjrițī und der latein. Übersetzung des Athelhard von Bath, (Det Kongelige Danske Videnskabernes Selskab, Skrifter, 7th Ser., Hist. og filos. Afd., 3.1), Copenhagen: Høst \& Søn, 1914.

Sylla, Edith Dudley, 'The Status of Astronomy as a Science in Fifteenth-Century Cracow: Ibn al-Haytham, Peurbach, and Copernicus', in Rivka Feldhay and F. Jamil Ragep (eds), Before Copernicus: The Cultures and Contexts of Scientific Learning in the Fifteenth Century, Montreal \& Kingston: McGill-Queen's University Press, 2017, pp. 45-78.

Thomson, S. Harrison, The Writings of Robert Grosseteste, Bishop of Lincoln 1235-1253, Cambridge: University Press, 1940.

Thorndike, Lynn, 'John of Seville', Speculum 34 (1959), pp. 20-30.

- Michael Scot, London: Nelson, 1965.

- 'Thomas Werkwoth on the Motion of the Eighth Sphere', Isis 39 (1948), pp. 212215.

Tihon, Anne, Le 'Petit commentaire' de Théon d'Alexandrie aux Tables faciles de Ptolémée: histoire du texte, édition critique, traduction, (Studi e testi, 282), Vatican City: Biblioteca Apostolica Vaticana, 1978.

Toomer, G. J., 'A Survey of the Toledan Tables', Osiris 15 (1968), pp. 5-174.

Vodraska, Stanley Luis, 'Pseudo-Aristotle, De causis proprietatum et elementorum: Critical Edition and Study', PhD Diss., University of London, 1969. 